Florida International University FIU Digital Commons

\title{
Collective Bargaining And Faculty Unionization: An Administrative Perspective
}

Colleen M. Quinn

Florida International University, cquinn@broward.edu

DOI: $10.25148 /$ etd.FI1 1072508

Follow this and additional works at: https://digitalcommons.fiu.edu/etd

\section{Recommended Citation}

Quinn, Colleen M., "Collective Bargaining And Faculty Unionization: An Administrative Perspective" (2011). FIU Electronic Theses and Dissertations. 424.

https://digitalcommons.fiu.edu/etd/424

This work is brought to you for free and open access by the University Graduate School at FIU Digital Commons. It has been accepted for inclusion in FIU Electronic Theses and Dissertations by an authorized administrator of FIU Digital Commons. For more information, please contact dcc@fiu.edu. 


\section{FLORIDA INTERNATIONAL UNIVERSITY}

Miami, Florida

\section{COLLECTIVE BARGAINING AND FACULTY UNIONIZATION:}

\section{AN ADMINISTRATIVE PERSPECTIVE}

A dissertation submitted in partial fulfillment of the

requirements for the degree of

DOCTOR OF EDUCATION

in

HIGHER EDUCATION

by

Colleen M. Quinn

2011 
To: $\quad$ Dean Delia Garcia

College of Education

This dissertation, written by Colleen M. Quinn, and entitled Collective Bargaining and Faculty Unionization: An Administrative Perspective, having been approved in respect to style and intellectual content, is referred to you for judgment.

We have read this dissertation and recommend that it be approved.

Roger Geertz Gonzalez

Glenda Droogsma Musoba

Benjamin Baez, Major Professor

Date of Defense: June 16, 2011

The dissertation of Colleen M. Quinn is approved.

Dean Delia Garcia

College of Education

Interim Dean Kevin O'Shea

University Graduate School

Florida International University, 2011 


\section{ACKNOWLEDGMENTS}

I would like to extend a heartfelt thanks to my committee members; Dr. Roger Geertz Gonzalez, Dr. Glenda Droogsma Musoba, and Dr. Lorna Veraldi. I not only appreciate the time that you spent reviewing my proposal, announcements and chapters but also for making me feel like I deserved your time and attention. In addition, I would like to acknowledge Dr. Linda Bliss and Dr. Isodore Newman. I appreciate the countless hours that both of you devoted to my dissertation. It was a humbling experience for me.

I would like to extend a special thank you to my committee chair, Dr. Benjamin Baez. Thanks Ben, for believing in me when I did not. I appreciate that you rode the wave with me through both the highs and the lows. I am not sure that I would have been able to complete this dissertation without your support, encouragement, and words of wisdom. Thanks for believing in me.

A big thanks to all of my friends and colleagues including those from my FIU Cohort. I appreciate all of the emotional support, the needed reality checks, and the assistance with the financial resources to help make my dream come true. It is truly an honor to come to work every day and to be a member of a group of individuals who are so committed to education and empowerment.

Last, but certainly not least, I would also like to thank all of the higher education administrators who participated in this study and who gave so willingly of themselves. I will always value the time that we spent together and will always appreciate that I am a better person because of each of you. You taught me about the importance of being authentic and not getting lost in the process of the everyday business of things. 


\section{DEDICATION}

This dissertation is dedicated to my family. To my Dad, thanks for always being on the bench. I know that you are watching over all of us, may God help you! To my Mom, thanks for instilling a sense of confidence and responsibility in all of your seven children. I hear your words often, "If you are going to do something, do it right!" To my brothers and sisters, Sean, Mary, Kathleen, Meg, Tricia, and Joe thanks for always playing school with me when we were all younger. All of that practice has paid off! Last, but definitely not least, I would like to thank John and Jake. John thanks for all of the support and encouragement along the way. It has been a long journey, but you never wavered! Jake, thanks for always encouraging me to go to work. While you may have had more than one motive, I know that you really do love me! I appreciate all of the extras that you did to make sure that I could work on this paper. 


\begin{abstract}
OF THE DISSERTATION
COLLECTIVE BARGAINING AND FACULTY UNIONIZATION:
\end{abstract}

AN ADMINISTRATIVE PERSPECTIVE

by

\author{
Colleen M. Quinn
}

Florida International University

Florida International University, 2011

Miami, Florida

Professor Benjamin Baez, Major Professor

The purpose of this qualitative case study was to gain insight into the perspectives of experienced higher education administrators regarding faculty unionization, the collective bargaining process, and the interpersonal relationships between higher education faculty members and administrators.

The primary method of data collection was semi-structured face to face interviews with nine administrators from two community colleges and two universities in the south Florida area. All of the study participants worked with unionized faculty members and had direct experience participating in bargaining negotiations.

Upon the completion of each interview, the researcher listened to the taped audio recording of the interview several times and then transcribed all of the information from the audiotape into a Word file. Data collection and analysis for each participant were performed concurrently. Using a modified concept mapping approach, the research questions were written on large yellow sticky notes and placed in the middle of a wall in the researcher's home with nine descriptive categorical themes written on smaller sticky 
notes placed around the study questions. The highlighted quotes and key phrases were cut from each transcript and placed under each of the descriptive categories. Over the course of a few months repeatedly reviewing the research questions that guided this study, the theory of symbolic interactionism, and relevant literature the categorical descriptive themes were refined and condensed into five descriptive themes.

Study findings indicated that the administrators: (a) must have a clear understanding of what it is that the faculty does to be an effective representative at the bargaining table, (b) experienced role ambiguity and role strain related to a lack of understanding as to their role at the bargaining table and a lack of organizational support, (c) were not offered any type of training in preparation for bargaining, (d) perceived a definite "us versus them" mentality between faculty and administration, and (e) saw faculty collective bargaining at public institutions of higher education in Florida as ineffectual. 


\section{TABLE OF CONTENTS}

CHAPTER

PAGE

I. INTRODUCTION 1

Synopsis of Literature Review $\quad 2$

Purpose of the Study 5

Conceptual Framework $\quad 5$

$\begin{array}{ll}\text { Research Questions } & 6\end{array}$

Study Delimitations $\quad 7$

Summary of Study Framework $\quad 8$

II. LITERATURE REVIEW 10

Higher Education Faculty Unionization and Collective Bargaining 11

Legal Issues Related to Unionization and Collective Bargaining In 14

Higher Education in the United States

Empirical Research: Unionization and Collective Bargaining In 20

Higher Education

Public Sector Collective Bargaining in Florida $\quad 26$

$\begin{array}{ll}\text { Symbolic Interactionism } & 28\end{array}$

Summary of Literature Review 32

III. METHODS $\quad 35$

Research Design $\quad 36$

Role of the Researcher $\quad 38$

Site and Participant Selection $\quad 42$

Data Collection and Management $\quad 47$

Data Analysis $\quad 51$

Credibility of Study Findings $\quad 57$

Summary of Study Methods $\quad 60$

IV. FINDINGS: PROFILES AND DESCRIPTIVE CATEGORIES 62

$\begin{array}{ll}\text { Study Participants' Profiles } & 64\end{array}$

$\begin{array}{ll}\text { Descriptive Categories } & 80\end{array}$

Reasons for Entering Higher Education Administration 81

Expectations of Administrators Related to Collective Bargaining 89

and Working with Unionized Faculty Members

$\begin{array}{ll}\text { The Negotiation Preparation Phase of Bargaining } & 106\end{array}$

Interpersonal Relationships Between Faculty and Administrators 111

The Legitimacy of Faculty Unionization in Higher Education 121

Summary of Profiles and Descriptive Categories 132 
V. CONCLUSIONS: FINDINGS, IMPLICATIONS, RECOMMENDATIONS 134 Study Overview 136

$\begin{array}{ll}\text { Discussion of Study Findings } & 142\end{array}$

Pre-requisite to Being an Effective Administrator on the Bargaining Team 143

$\begin{array}{ll}\text { Role Ambiguity and Role Strain } & 147\end{array}$

Inadequate Preparation for Collective Bargaining Negotiations 150

Us Versus Them 152

The Faculty Bargaining Process in Florida is Ineffectual 157

Additional Recommendations Related to Theory and Research 160

Study Summary and Concluding Thoughts 162

$\begin{array}{ll}\text { REFERENCES } & 165\end{array}$

$\begin{array}{ll}\text { APPENDICES } & 176\end{array}$

$\begin{array}{ll}\text { VITA } & 183\end{array}$ 


\section{CHAPTER I}

\section{INTRODUCTION}

The future of organized labor unions and collective bargaining has reached a critical crossroad in the United States. Mauer (2001), an attorney who served on the National Labor Relations Board, defined collective bargaining as "the process of face-toface meetings, exchange of proposals, and give and take that produces a union contract" (Mauer, 2001, p. 125). Union membership and the number of collective bargaining units began to decline in the industrialized sector in the United States in the late 1970s. Speculation regarding causes for the decline included the transition from being a nation highly dependent upon a labor intense industrialized work force to being a nation highly dependent upon technology and a more individualized technological competitive workforce, poor union organization and membership drives, government deregulation, increased employer dependence on part-time transitory employees, and negative attitudes of employers toward unionization and collective bargaining (Gunderson, 2005; LeBlanc, 1999; Yates, 1998).

At the same time unionization and collective bargaining in public institutions of higher education had just begun to reach a level of recognition with the number of unionized universities increasing from 13 to over 500 in a 10 year period from 1970 to 1980 (Ashraf, 1997). The first higher education faculty collective bargaining unit was formed in 1965 at a community college in Michigan (Castro, 2000). Faculty benefits attributed to the advent of faculty unionization and collective bargaining include job security and equity, enhanced fringe benefits, reimbursement for professional development, and competitive salary increases (Babcock \& Engberg, 1999). 
Recognizing the protection and benefits that have come about for unionized faculty members, it is imperative that one takes the time to examine the level of involvement and the possible influence that administrators may have related to faculty unionization and collective bargaining. Duryea, Fisk, and Associates (1973) called for higher education administrators to realize that they are accountable to faculty members and recognize that they are a crucial constituent in higher education. Based on the theory of symbolic interactionism (Blumer, 1969; Mead, 1934; Stryker, 1980), the perceptions of these higher education administrators and their related dynamics with faculty members and each other impact their attitudes and behaviors while working with unionized faculty members and participating in the collective bargaining process. In an effort to better understand the impact of working with unionized faculty members and collective bargaining in higher education, the purpose of this study was to explore and explain the perceptions of higher education administrators who have worked with unionized faculty members and actively participated in union negotiations. Appreciating that there has not been much written from the administrative perspective, a qualitative case study approach was utilized.

\section{Synopsis of Literature Review}

The contemporary higher education administrator is faced with a dynamic terrain. Slaughter and Rhoades (2004) described a shift from academic capitalism to academic corporatization. Shumar (1997) compared today's institution of higher education to a factory composed of managers, employees, and consumers. The driving force behind such was economic efficiency. Enhanced efficiency measures include quick turnaround times, lack of shared governance, and a bureaucratic organizational re-structuring. In 
response to this rugged and often twisted terrain, increased competition and a finite pool of financial resources, the chief academic officers in these institutions are faced with multiple realities and allegiances. The call for quality, regulation, and collaboration comes from not only faculty members, students, and higher ranking administrators within the academic institutions, but also from community and business liaisons, research sponsors, and state and federal legislatures and courts (Anderson, Murray, \& Olivarez, 2002; Bowker, 1981; Mech, 1997).

The collective bargaining process requires the active and willing participation of both faculty members and higher education administrators. Birnbaum (1988) cautioned that when deciding whether or not to participate in work related activities, both faculty and administrators should calculate the costs and benefits related to these activities. The perceived benefit must outweigh the cost for one to actively participate. Social behaviorists indicate that for any effective exchange to take place between individuals or groups of individuals, both parties must gain something (Blumer, 1969; Eisenberger, Stinglhamber, Vandenberghe, Sucharski, \& Rhoads, 2002). While collective bargaining was proven to be beneficial for faculty members, little is known about the administrators' cost-benefit analysis.

A study completed in the late 1990 s revealed that among the factors most closely related to a faculty member's decision to seek out unionization was the overall dissatisfaction with salary and the work environment, most notably the level of communication between faculty and administrators (Benedict, 1999; Rassuli \& Karim, 1999). In addition, faculty members seek representation when morale is low and unemployment rates are high (Hemmasi \& Graf, 1993; Myers, 2003). In one of the 
earliest studies related to bargaining and unionization in higher education, Odewahn and Spritzer (1976) reported that chief academic officers from public and private higher education institutes reported mixed reviews related to faculty unionization and collective bargaining. The majority of returned surveys in their study indicated that these higher education administrators were of the conviction that faculty unionization and collective bargaining would result in greater mediocrity, increased divisiveness in academic lives, and a lack of commitment in the pursuit of those objectives that would be in the best interest of the college. When the responses were sorted between those that came from respondents who actually had hands on experience working with unionized faculty members and those who had none, the majority of those administrators who did have the direct experience agreed that unions played a legitimate role in higher education. When asked for an overall opinion regarding the acceptance of faculty unionization and collective bargaining, $48 \%$ of the surveyed administrators were opposed to such, $45 \%$ were neutral, and $7 \%$ of the administrators favored unionization and collective bargaining privileges for faculty (Odewahn \& Spritzer, 1976).

Duryea et al. (1973) interviewed 54 administrators and asked them to rate the effectiveness of collective bargaining on educational programs and campus governance. The majority agreed that collective bargaining had more of a negative effect than a positive one. The majority of these same 54 administrators did go on to cite some positive effects of higher education collective bargaining including equity in salary increases, a clear delineation of managerial rights and acceptance of the same, the establishment of employee relations offices for the handling of routine aspects of issues related to human 
resources, and the placement of more responsibility on the faculty for determining professional conduct and holding their peers accountable.

The results from both of these earlier studies indicated that the administrators interviewed had mixed feelings related to faculty unionization and the benefits of collective bargaining. These studies were conducted when faculty unionization and faculty and administrative involvement in collective bargaining had just come about. Current studies examining how faculty unionization and collective bargaining has impacted today's higher education administrator could not be found.

\section{Purpose of the Study}

The meaning that the collective bargaining process has for these administrators, as well as their understanding of the group dynamics involved in terms of their understanding of the relationship between higher education faculty and administration, was explored.

\section{Conceptual Framework}

Symbolic interactionism implies that human beings are active, dynamic participants in the creation of their reality (Blumer, 1969; Mead, 1934; Stryker, 1980). As such, each individual constructs his or her unique reality based on the meanings derived from interacting with others (Blumer, 1969). Consistent with symbolic interactionism, to understand the perspectives of the higher education administrator as related to faculty unionization and collective bargaining and a structural type of analysis of group behavior, one must examine how this perspective came into being. An examination of this process focused on what it was that the administrator focused on during the experience, how that administrator defined that episode, relationship or symbol, and how that same individual 
interpreted the meaning of such (Blumer, 1969). It is what happens leading up to these bargaining sessions, during these sessions, and after the bargaining sessions that will, in turn, influence the actions of both the administrators and the faculty members when working together and participating in union negotiations. While recognizing that both sides of the table may be committed to the same institutional vision and mission, it is also necessary to simultaneously realize that no two people who have shared in the same experience may see that relationship, episode, or symbol in the same way (Blumer, 1969). A clearer understanding of the administrative perspective and the underlying diversity, or lack thereof, will assist all of those involved in the collective bargaining process to better appreciate the complexity involved.

\section{Research Questions}

Shortly after the advent of collective bargaining in our institutions of higher education, Birnbaum (1980) stated that faculty unionization and collective bargaining in higher education could be useful in bringing about institutional change or destructive by causing much conflict. Symbolic interactionism focuses on the meaning of group behavior and events and the effect that those involved in the group process have on each other (Stryker, 1980). Higher education administrators play a crucial role in the collective bargaining process. This study attempted to answer the following research questions:

1. What are the administrators' perceptions of the collective bargaining process and faculty unionization in higher education after having participated in both roles? 
2. What are the administrators' perceptions of the factors of unionization and collective bargaining with regard to the interpersonal relationship between faculty and administration?

\section{Study Delimitations}

Critics of the qualitative study design often cite problems of validity, reliability. and extensive researcher bias and affect related to the use of a small, purposeful study sample, as well as the amount of time and the involvement of the researcher in the data collection, management, and analytic phases of the study (Bogdan \& Biklen, 2007; Fraenkel \& Wallen, 2003; Seidman, 2006). A small, purposeful sample was necessary for an in depth collection and analysis of the data related to the particular experience of having participated in collective bargaining sessions as an administrator and working with unionized faculty members. The small sample size afforded the researcher the opportunity for a deeper exploration and description related to the meaning of collective bargaining held by the nine college and university administrators interviewed. It is not the intent of this researcher to present the findings from this study as being generalized to any other context other than the specific setting and sample included in this study. Instead, the researcher followed the lead of Fraenkel and Wallen (2003), who suggested that it is not up to the researcher to judge the relevance of the study findings for a particular practitioner. It is instead up to the reader/practitioner to determine the applicability of the study and the study findings to her or his situation or context.

While broad generalizations are not the purpose of qualitative research, the gathering, analysis, and dissemination of the study findings may be of benefit to higher education administrators and faculty members, as well as to those who interact with these 
groups. Interviewing a small number of participants afforded the researcher the opportunity to gain a more in depth understanding of what it is or was like for each participant to work with unionized faculty members and to participate in the collective bargaining process. Taking part in the study interview, each participant was offered an opportunity to reflect upon the experience and share lessons learned. Individuals who read the study can determine if the findings and implications are relevant to their particular setting and situation

\section{Summary of Study Framework}

Faculty members attribute the financial rewards, job security, and level of job satisfaction related to shared governance they experience to the concentrated efforts of unionization and collective bargaining (Ashraf, 1997; Benedict, 1999; Benedict \& Wilder, 1990; Castro, 2000). In today's economically challenging environment, these benefits cannot be taken lightly nor can the protection of such. The collective bargaining process is complex and composed of many intricate relationships and experiences. The perception and effects of these experiences are contributing factors to the resulting behaviors that will be displayed by the higher education administrators involved in the bargaining process (Blumer, 1969). This study considered two primary questions related to the administrative perspective of what it is like to work with unionized faculty members while participating in the collective bargaining process. and the perceived effects of unionization and bargaining on the academy and interpersonal relationships between the individuals and groups involved. Specifically, the study questions that guided this dissertation included an in depth exploration of the administrative perception of the collective bargaining process and faculty unionization in higher education after 
having participated in both roles, and the administrative perception of the factors of unionization and collective bargaining with regard to the interpersonal relationship between faculty and administration.

The history of collective bargaining in the industrial sector, as well as in higher education, along with the legal issues and current study findings as related to faculty unionization and collective bargaining in institutes of higher education in the United States are discussed in the next chapter. Additional chapters describe the study methods used, the reported findings from the nine administrators interviewed, and a discussion section including the integration of the study findings to the existing literature in terms of descriptive categories, interpretations and conclusions reached, and the related recommendations for theory, practice and research. 


\section{CHAPTER II}

\section{LITERATURE REVIEW}

Employee unionization and collective bargaining originated in $20^{\text {th }}$ century America in the midst of an economic depression and during a period of intense labor unrest. The original intent of workers bargaining as a unit rather than individually was to balance the playing field in the workplace between employee and employer in an attempt to protect the rights of the employee in relation to wages, benefits and workplace conditions (Bain, 1970; Kaufman, 2005). With the intercession of the federal government in 1935, unionized private sector employees were afforded bargaining protection in part to promote social equity and democracy in the workplace while at the same time attempting to avoid any disruption of commerce (McCartin, 2008; O’Connell, 2001; Vinel, 2007). In the public sector, unionization and the afforded protection of employee bargaining rights did not gain a strong foothold in the United States until nearly a quarter of a century later with the passing of Kennedy's Federal Executive Order 10988 in 1962 (Falvey, 2002; Piskulich, 1992). The subsequent passing of state laws defining membership eligibility, the latitude of bargaining issues, and the degree of permissiveness of public sector strikes followed.

This chapter includes a brief history of collective bargaining in the United States and, in particular, in higher education. While the focus of this study is to capture the meaning and perceived effects of faculty unionization and collective bargaining as experienced by administrators in public institutions of higher education, a brief synopsis of the Yeshiva case will be presented. Although Yeshiva is a private institute, this case 
deals with the many implications related to the delineation of faculty versus administrator and the related perceptions and relationships between these partners in higher education.

For the purpose of this study, higher education administrators will be defined as those administrators at the community college, college, and university levels who by institutional definition are labeled as administrators and thus are not afforded union membership protection. The demographics of this group of administrators, along with information related to their educational backgrounds and experiences, will be discussed. Before offering a brief summary, a discussion of the theoretical framework used in the conception of this study, symbolic interactionism, (Blumer, 1969) will be included.

Higher Education Faculty Unionization and Collective Bargaining

With the favorable post-World War II economic conditions and the call for social equity in the United States in the early 1960s, enrollment in institutions of higher education surged (Thelin, 2004). The fast and vast increase in the volume, as well as in the diversity of the students entering these institutions, called for a dramatic increase in facility size, number of faculty needed, diversity of faculty, and the multifaceted specialization of services. Higher education began to experience a substantial increase in growth leading to economic stability, however, at the same time the higher education academy experienced institutional and professoriate fragmentation (Duryea et al., 1973; Garbarino \& Aussieker, 1975). Faced with an opportunity to explore improved financial and fringe benefit advancements and the need to address the separation of faculty and administration with the increasing bureaucratic styles of management being brought into institutions of higher education in an effort to manage the size and fragmentation new to 
higher education, faculty members began to unionize and collective bargaining in higher education came to a realization in the early 1960s.

Almost a half of a century later institutes of higher education continue to undergo rapid change. Many of these same concerns that plagued faculty members, administrators, education consumers, the general public, and politicians fifty years ago continue to present a challenge today. Locally and globally, the populace continues to look toward education to solve many of its problems including the preparation of citizens to participate in a democracy, the advancement of the individual and impoverished groups in society, the promotion of the understanding of cultural diversity, the intellectual and technical preparation of the populace for the job force and current state of economic and intellectual global competitiveness, as well as the overall improvement of the nation and its people (Levin, 2000). Institutions of higher education continue to expand their missions while grappling with what are perceived to be the limitations of a diminished, finite resource base often leaving both faculty and administration frustrated.

Historically, in an effort to temper the effects of the felt frustrations, higher education faculty members and administrators have often acted in what has been perceived to be in opposition with each other while attempting to meet the demands of both the internal and external groups of higher education constituents (Birnbaum, 1980). Unionization and the collective bargaining process have been one of the main vehicles used by faculty to make their voices and concerns heard. Adopting the collective bargaining tenets and process from the industrialized labor force, these professional faculty members have sought equality and the opportunity for shared governance in those academic issues related to the educational and research processes and the acquisition of 
the needed resources in the workplace. Unions in public colleges and universities continue to represent the majority of faculty members employed in these institutions of higher education with approximately $90 \%$ of all unionized faculty members working in public as opposed to private institutions of higher education (Benjamin \& Mauer, 2006). Therefore, the majority of administrators at public institutions work with unionized faculty members and it is these administrators who contribute to issues related to employment, work conditions and decisions that affect the classroom and the institution at large (Kaplin \& Lee, 1995; K-20 Education Code, 2010). Consequently, it is imperative that one understands the perspectives of those administrators making these decisions and participating in the collective bargaining process.

The purpose of this study is to describe and explain the perspectives of these college and university administrators regarding their administrative perspectives while working with unionized faculty members and participating in the collective bargaining process. In particular, how they give meaning to the collective bargaining process and how it is that they understand the relationship between faculty and administration and the impact of this assigned meaning and understood relationships in today's institutes of higher education. From a sociological, interactive framework the perspectives that these administrators hold relating to unionization and the collective bargaining process will play a major role in their decision making (Birnbaum, 1980; Blumer, 1969). These perspectives will be influenced, in part, by the relationships that they have with faculty members and other administrators participating in the process. In addition, these perspectives and resulting actions will influence the decision making processes and related actions of the involved faculty members. Ultimately, it is the faculty member who 
will be affected by the decisions made in these institutes that have the greatest impact on what happens in the classrooms and research areas in the U.S. institutions of higher education.

Before attempting to better understand the administrative perspectives regarding higher education faculty unionization and collective bargaining from those who have direct experience with the process, it is necessary to explore the framework of collective bargaining from a legal, procedural and empirical foundation to gain some insight as to the possible groundwork for some of these perspectives, as well as the external expectations related to unionization and collective bargaining. When looking at the personalized accounts and the everyday experiences of higher education administrators, it is also important to examine the composition of today's university and college administrators, as well as their career paths. All of these factors and interactions contribute to their experiences, perceptions, and ultimately their decision making processes as related to the collective bargaining process and participation in contract negotiations while working with unionized faculty members (Blumer, 1969).

Legal Issues Related to Unionization and Collective Bargaining in Higher Education in the United States

While unionization in the industrialized workforce actually began in the $1800 \mathrm{~s}$, mostly through the formation of craft guilds, employee protection and mandated administrative participation in collective bargaining did not come about in the United States until the early 1900s with the passing of the National Labor Relations Act (NLRA), also known as the Wagner Act (LeBlanc, 1999; Piskulich, 1992). The NLRA, signed by Roosevelt in 1935, offered industrialized workers protection while granting 
them the opportunity to choose unionization and the right to choose whether or not to bargain collectively (O'Connell, 2001). Roosevelt, along with members of the U.S. Senate, appointed five board members and a lawyer to a newly formed National Labor Relations Board (NLRB), an independent federal agency to enforce the act. The NLRB was charged with the responsibility to decide the merit of the cases of those bargaining units seeking voting privileges. The NLRB was set up to assure the private workforce sector employee the right to conduct a secret ballot election to determine employee interest in collective bargaining once a proposal was filed seeking unionization. In addition, they were responsible for the protection of these collective bargaining units from unfair labor practices by the employer. To date, the NLRB has managed close to one million cases involving employee complaints of unfair labor practices and is responsible for over a quarter of a million secret-ballot union adoption elections in the private sector workplace (Benjamin \& Mauer, 2006). An analysis of 500 case decisions made by the Board from 1957 to 1986 indicated that the majority of the cases $(80 \%)$ were uncomplicated and decided at the regional level (Cooke, Mirsha, Spreitzer, \& Tschirhart, 1995).

In 1947, partly in response to a Supreme Court decision as to the classification of foremen at Packard Motor Car Co. 17, the Taft-Hartley Act was passed by The U.S. Congress (Vinel, 2007). The Supreme Court, in agreement with the NLRB, recognized the distinction between capital and labor, as well as manager and employee. The Wagner Act sought to protect the right of the employee. There were no specific guidelines related to the stratification of the supervisory role. There were and continues to be many presumptions made as to this classification. In the case of the foremen at the Packard 
Motor Company, the NLRB ruled that the company foremen composed the lowest administrative level at the plant. In addition, due to plant restructuring, these foremen no longer had a say in matters related to employee benefits such as pay, rank, promotions or layoffs. The foremen were thus considered employees and as such were afforded protection under the NLRA.

The industrial capital side of the industry was quick to seek clarification. Despite the protest of then President Harry Truman, the Taft-Hartley Labor Act, also known as the Labor-Management Relations Act was enacted in 1947. This amendment to the Wagner Act included articles related to employer protection, such as the right to an 80 day injunction against an employee strike, no protection for employees who were out on a strike that was not authorized by the labor union, the prohibition of the closed shop forbidding employers to require an employee to be a member of a union as a condition for employment, and the allowance for a union shop only if the majority of employees voted it in (Goldberg, 2000). The Taft-Hartley Labor Act also specifically precluded supervisors from coverage under the Wagner Act.

The Landrum-Griffin Act, also known as the Labor Management Reporting and Disclosure Act, was an additional effort to thwart the power of big unions. It was passed in 1959 in an effort to curb corruption in many local and national unions (Goldberg, 2000). The act required unions to utilize democratic procedures when conducting business and membership drives, guaranteeing all members the right to free speech and association, and to submit detailed financial reports to the federal government.

While the bargaining rights of the employees in the private sector, including the higher education private sector, are protected under these federal mandates, the 
employee's right to seek unionization and representation in the public sector is covered predominately under state statute (Piskulich, 1992; Public Employees Relations Committee, 2004). In 1962, President Kennedy opened the door to collective bargaining for federal employees. Soon thereafter, state and local governments followed. In 1963, Milwaukee Technical College was the first two year college to unionize, followed three years later by the U.S. Merchant Marine Academy, a four year college (Metchick \& Singh, 2004). While there is some variation amongst individual state statutes, there is also a degree of cohesiveness. Most states have a no strike clause for public employees and the collective bargaining process and related responsibilities for both parties (employee and management) involved are clearly delineated under state statute, as well as the appeal process should a resolution not been reached (Piskulich, 1992). To date, not all states offer protection under state statute.

As is true for the industrialized sector, the bargaining issues, procedures and related statutes are similar between the private and public higher education institutions. The biggest contemporary distinction, however, between the two sectors involves the inclusion or exclusion of faculty protection and the types of governing boards responsible to necessitate that faculty and administration bargain in good faith. While the federal NLRB has the oversight for unionization and collective bargaining in the private sector, each state has its own oversight agency (Piskulich, 1992). In Florida, the Public Employee Relations Commission (PERC) oversees the constitutional right of public employees to collectively bargain in regards to wages, hours, and terms and conditions of employment and assists in the resolution of contractual disputes (Public Employees Relations Commission, 2004). 
The case perhaps most responsible for illuminating the inclusion/exclusion of faculty members guaranteed collective bargaining rights in the private higher education sector is the Yeshiva case. This landmark 1980 Supreme Court case, NLRB $v$. Yeshiva University 1980, was a pivotal turning point for collective bargaining for both the private and the public sectors of higher education. Upholding an appellate court decision, the Supreme Court in a 5-4 decision declared that the faculty members at Yeshiva, a private university were considered managers as defined by the National Labor Relations Act. As such, these employees were not entitled to protection under the Wagner Act and the NLRA in matters pertaining to collective bargaining. In the case of faculty members at Yeshiva, it was determined that the faculty held a considerable amount of authority in both academic and nonacademic matters related to the university (Metchick \& Singh, 2004). The courts declared that faculty members held absolute authority in those academic matters related to course coverage, offerings, and requirements for graduation, teaching methodology, and grading criteria. This authority ultimately impacted which students were retained and which students would graduate. Furthermore, it was determined that the faculty held a considerable amount of authoritative decisive power in those nonacademic matters such as the hiring, firing, promotion and tenure of faculty members (Metchick \& Singh, 2004).

These somewhat confusing criteria in the areas of professional versus managerial roles and responsibilities, the use of independent judgment in the carrying out of any of the twelve duties deemed managerial related to the hiring, promotion and retention of employees, and the concern that the employer is entitled to the undivided loyalty of its representatives, continue to be applied by the NLRB when determining which faculty 
working in private institutions will be afforded protection and which will not. This was evident in subsequent rulings related to the classification of nurses as supervisors who were then not entitled to protection under the NLRA (NLRB v. Health Care and Retirement Corporation of America, 1994). The NLRA defined a manager as one who holds authority in the interest of the employer and uses independent judgment while engaging in one of twelve activities including the hiring, terminating, suspending, laying off, recalling, promoting, discharging, assigning, rewarding, disciplining, directing or adjusting the grievance of an employee or effectively recommending such action. A professional is defined as one who requires advanced knowledge by a prolonged course of intellectual instruction and who is employed in a type of work that is predominately intellectual in character, varied (as opposed to routine manual or physical labor), and involving the consistent use of discretion and independent judgment (NLRB v. Health Care and Retirement Corporation of America,1994).

Not only did the Yeshiva case set a precedent for the determination of entitlement to collective bargaining protection in private colleges and universities, this case also set a precedent in changing that once dotted line to a solid line differentiating and separating faculty from administration in higher education decision making, forcing each to stand on one side or the other and hold their positions. This differentiation served to place those faculty members and administrators in institutions of higher education in the same arena of those in industry and corporatization related to a top down management style versus the shared governance model that previously distinguished higher education from the industrial, corporate world. Though this differentiation may have gone unnoticed at the 
time, the repercussions are still being felt by faculty and administrators today in colleges and universities across the United States.

In addition, the degree of involvement of the Supreme Court in matters related to education is significant. Historically, before this landmark case the courts stayed clear of decisions related to academia recognizing that the structure of the academic system is not the same as the industrialized working sector, especially in the different relationship of industrial employee and faculty to their supervisors and the concept of shared governance in the college and university systems. A significant element of the Yeshiva case is that for one of the first times in higher education, the administration fought the faculty in their attempt to unionize.

Empirical Research: Unionization and Collective Bargaining in Higher Education While union membership in the private higher education sector has experienced a dramatic decline over the past decade, due in large part to the conservative political climate present prior to the 2006 and 2008 elections and increased court involvement, the same has not been true for the public sector (Benjamin \& Mauer, 2006). Collective bargaining has brought about competitive workforce salaries and heightened unpaid fringe benefits including job security, health insurance coverage, paid time off, opportunities for professional development, promotion and tenure (Ashraf, 1997; Babcock \& Engberg, 1999; Benedict, 1999; Benedict \& Wilder, 1990; Hannay, 2002). While recognizing the positive impacts of bargaining, there has been a growing concern amongst faculty and administrators relative to the negative impacts that the unionization of professional faculty members and the resulting bureaucratization necessary to implement the union contract has had on the professoriate and on the advancement of the 
overall core mission of all institutions of higher education dating back to the inception of unionization and bargaining in higher education (Birnbaum, 1980; Duryea et al.,1973).

The main concerns facing higher education employees related to the heightened bureaucracy are related to the growing opposition between faculty and administration and the loss of shared governance (DelFavero, 2003). These concerns, which led to the initial demand for unionization in some instances, have often resulted in continued frustration on the part of both administrators and faculty members. Birnbaum (1980), Professor Emeritus from the University of Maryland, cautioned his colleagues that faculty unionization had the potential for both constructive as well as destructive organizational outcomes. Frustration, experienced by either of the parties involved in the bargaining process due in part to unrealistic expectations, a lack of understanding regarding the process and meaning of the bargaining relationship, and an increase in the scope of bargaining in Birnbaum's opinion, is more likely to result in destructive organizational outcomes. Faculty members continue to seek unionization and collective bargaining especially when morale is low, unemployment rates are high, and there is poor communication between faculty and administrators (Hemmasi \& Graf, 1993; Myers, 2003).

It was not my intent to advocate for or against faculty unionization and the current collective bargaining process. Much of the literature related to higher education and the unionization of faculty members was written in the late 1960s and early 1970s as a response to how faculty unionization and collective bargaining came about and the projected professional and institutional consequences of both. Many of the books and articles reviewed for this paper were based on conjecture. Now that faculty unionization 
and higher education collective bargaining has a history, the purpose of this study was to gain an understanding of the administrative role, experience and perspectives related to the unionization of faculty members in higher education and the collective bargaining process, as well as the implications of such in terms of interpersonal relationships from the perspective of the administrator who has participated in bargaining and worked with unionized faculty members. From a sociological perspective, these experiences and attitudes, in turn, affect the faculty-administrator relationship both at the bargaining table and in the everyday workplace (Blumer, 1969; Eisenberger, Huntington, Hutchison, \& Sowa, 1986).

Odewahn and Spritzer (1976) argued that for collective bargaining to be successful, both faculty and administrators must believe that each faction plays a significant role in promoting the mission of the institution. In a 1973 study conducted with Chief Academic Officers via a mail-in survey, they reported the majority of these higher education officers from both public and private higher education institutes believed that faculty unionization and collective bargaining would result in greater mediocrity, increased divisiveness, and a lack of participation in achieving institutional goals. Yet, when the responses were sorted between those that came from respondents, who actually had experienced faculty unionism first hand and those who had not, the majority of those administrators who had direct experience did agree that unions played a legitimate role in higher education. When asked for an overall opinion regarding the acceptance of faculty unionization and collective bargaining, $48 \%$ of these administrators were opposed to unionization, $45 \%$ were neutral, and $7 \%$ favored unionization and collective bargaining privileges for faculty (Odewahn \& Spritzer, 1976). 
Fifty-four administrators were interviewed in another study and asked to rate the effectiveness of collective bargaining on educational programs and campus governance. The majority agreed that collective bargaining had more of a negative effect than a positive one. The majority of these same 54 administrators did, however, indicate that there were some positive effects of bargaining including equity in salary increases, the clear delineation and acceptance of managerial rights, the establishment of employee relations offices for the handling of routine aspects including those issues related to human resources, and the placement of more responsibility on the faculty for determining professional conduct and holding their peers accountable (Duryea et al., 1973). These studies demonstrate that there are some differences in the reported perceptions of administrators toward faculty unionization and collective bargaining.

Others have written about the perceived threats related to faculty unionization and the collective bargaining process, such as the increase of conflict between internal constituents in the organization related to power and resources and the dissolution of communication between faculty and administration (Birnbaum, 1980; DelFavero, 2003). While these concerns may have held an intuitive appeal for some readers of these earlier published articles, there was not a substantial amount of evidence presented to support these beliefs. Benjamin and Mauer (2006) credit collective bargaining in higher education with being responsible for an actual reduction in campus conflict between faculty and administrators.

Birnbaum (1980) advocated for the recognition of the potential for collective bargaining in the academic sector to lead to either constructive or destructive organizational outcomes depending upon the perceptions and symbolism of the behaviors 
of those involved in the actual negotiations. In an earlier discussion about the potential for destructive conflict to lead to negative outcomes, Deutsch (1973) cited seven variables that lead to constructive or destructive conflict resolution that were discovered during his various research projects. Among the variables presented by Deutsch are the beliefs of the participants regarding conflict, the attitudes, beliefs and expectations that the participants have for and about one another, and the beliefs that each of the participants has about how the others view him.

An estimated $60 \%$ to $70 \%$ of today's academic leaders in higher education are men over the age of 50 who have worked at their current institutions for more than 5 years. The majority of these academic leaders have been in their current positions for $4 \frac{1}{2}$ to $5 \frac{1}{2}$ years, hold doctoral degrees, and earn over $\$ 50,000$ per year. Most have moved up internally or via lateral transfer within higher education and are satisfied with their careers and career choices, although many report high levels of role conflict (Anderson et al., 2002; Bowker, 1981; Cejda, McKenney, \& Burley, 2001; Murray, Murray, \& Summar, 2000). While the majority of higher education administrators are males, the number of female administrators is rapidly increasing. One study reported that the number of female chief academic officers has increased $26 \%$ over the past 20 years (Amey, VanDerLinden, \& Brown, 2006). It has been estimated that close to $70 \%$ of these administrators working in the community college/college setting work with a faculty body represented by a bargaining unit (Murray \& Murray, 1998).

The roles of these chief academic officers include the integration of interests of the various academic constituencies and disciplines in terms of creating a common purpose and institutional commitment, committee work, student counseling related to 
academic affairs and procedures, information dissemination between students, faculty and administration, resource allocation, disturbance handling, serving as community liaison, research teaching figurehead, or spokesperson, and negotiating collective bargaining agreements (Anderson et al., 2002; Bowker, 1981; Mech, 1997). With the current trend to expand the mission statements at many of these colleges and universities, the list of expectations continues to grow.

A study of community college presidents in the year 2000 indicated that about $50 \%$ of the higher education presidents hold a Ph.D. This was an increase from a previous study conducted in 1985 that indicated only about 40\% held a Ph.D. (Amey et al., 2006). In regard to formal training for their current administrative roles, though the majority of administrators hold doctoral degrees, one study by Brown, Martinez \& Daniel (2002) reported that over $60 \%$ of the administrators interviewed who were employed at two year public community colleges from 46 states disclosed that the needed job skills were not taught in their doctoral programs. The reported unaddressed areas included connecting theory to research and understanding how race, ethnicity, gender, and social class (issues related to the contemporary higher education institution) affect the individual's experience and related perceptions. Other studies reported administrative training deficits in the areas of conflict resolution, managerial skills, role responsibilities, and skills needed for decision making (Birnbaum, 1988; Mech, 1997; Murray et al., 2000).

The literature affiliated with faculty unionization and collective bargaining in higher education from the viewpoint of the administrator is sparse. Most of the studies have looked at why faculty members unionize including the issues over which they 
bargain, the historical context of collective bargaining in the United States, and the collective bargaining process and related state statutes and federal laws. Other reports from academicians involve conjecture over the perceived perceptions of faculty and administration related to collective bargaining, the place of the industrialized model of collective bargaining in the professional world of academia, and the consequences of collective bargaining. To gain a better understanding of the beliefs that higher education administrators hold toward collective bargaining and faculty unionization, a sociological framework based on symbolic interactionism (Blumer, 1969) was utilized.

Public Sector Collective Bargaining in Florida

State legislation concerning collective bargaining for employees in the state of Florida initially came into being in 1943 with the amendment of the Florida Constitution. In 1946, the Florida Supreme Court interpreted the 1943 amendment as not giving public employees the right to bargain collectively, picket, or strike. It was not until 1969 that the Florida Supreme Court upheld a new constitutional provision guaranteeing the rights of public employees to bargain collectively. The right to work section of the constitution was revised in 1968, thereby giving the public sector employee the right to work whether or not they joined the union representing the employees in the place of employment (Public Employees Relation Commission, 2004). Prior to the passing of this legislation, employees could be fired or refused hire if they did not pay dues by a specified date as determined by the union representing labor at each institution.

The bargaining unit for faculty members at the colleges and universities in the Southeast section of Florida cited in this study is The United Faculty of Florida (www.unitedfacultyofflorida.org). The United Faculty of Florida (UFF) is the bargaining 
agent representing faculty members at $32 \%$ of the community colleges in Florida. The UFF represents faculty members from 11 Florida state universities, 11 Florida colleges (formerly called community colleges), three independent universities based in Florida, and graduate assistants from three of the aforementioned Florida state universities. There are a president and vice president of UFF, along with four Bargaining Council Vice Presidents. In addition, each of the colleges and universities represented has its own faculty elected union chapter president.

In Florida for about 25 years, state-wide agreements were bargained between the Florida Board of Regents and the union (UFF) for the 11 Florida universities in the State University System (SUS). Following a rejection for requests for an additional law school in southeast Florida, a medical school at Florida State University (FSU), a law school to serve the residents in the middle of the state, and a request to re-open the law school program at Florida Agricultural and Mechanical University (FAMU) by the Florida Board of Regents who stated that financially Florida was not in a position to support 10 research universities after an 11 million dollar proposed cut by Governor Bush for higher education, the Florida legislature abolished the Board of Regents in Florida. The statewide Board of Regents was replaced with a separate Board of Trustees for each of the eleven SUS universities in Florida in 2000-2001. Shortly thereafter, former democratic Governor Graham supported a constitutional amendment to create a statewide Board of Governors (BOG) to oversee the individual board of trustees from each of the 11 universities in the SUS. This was passed by the voters in the 2002 election. In January, the BOG in its first meeting designated all of its authority to the 11 university Boards of Trustees (Fiorito \& Gallagher, 2006; Trombley, 2001). 
Following the devolution of bargaining from a centralized, state level to the local university level, eight of the universities' boards of trustees voluntarily recognized UFF as the faculty's representing union after the filing of authorization cards from over $65 \%$ of the faculty at each university. Three of the universities' board of trustees held out, not recognizing UFF. The boards of trustees' from Florida State University (FSU) and the University of West Florida (UWF) claimed that there was no successor obligation when the new board of trustees took over. The Public Employees Relations Commission (PERC) sided with the boards of trustees' from FSU and UWF. This PERC ruling was later reversed by the District Court of Appeals in 2005 stating that administrative reorganization does not provide sufficient grounds for the revocation of faculty bargaining rights and both FSU and UWF were obligated to the collective bargaining agreements that they inherited from the former Florida Board of Education (United Faculty of Florida and Florida Public Employees Council 79, American Federation of State, County, and Municipal Employees, AFL-CIO, Appellants, v. Public Employees Relations Commission, Florida State University Board of Trustees and University of West Florida Board of Trustees, Apelles, ID03-4689 (2005).

\section{Symbolic Interactionism}

In an effort to understand the perspectives of higher education administrators toward collective bargaining and faculty unionization, a sociological framework based on symbolic interactionism (Blumer, 1969) was utilized allowing for the recognition that each administrator interviewed will have a unique perspective related to unionization and bargaining and the perceived effects of such. Each unique perspective is based on one's history, experiences and relationships, interactions with others, and the definition of one's 
self as described by the individual. It is this perspective that will determine what it is that the administrator pays attention to in the intentional decision making process related to that object, symbol or event leading to the final behaviors related to that event (Blumer, 1969). The experiences, behaviors, and perceptions of the administrators play a crucial role in the achievement of institutional effectiveness as they will affect all of the internal constituents, especially in terms of job satisfaction and commitment in terms of the level of perceived organizational support experienced by all of the organizational key players (Eisenberger et al., 2002). This researcher sought to gain insight as to the administrative perspective of collective bargaining and faculty unionization by addressing two primary research questions:

1. What are the administrators' perceptions of the collective bargaining process and faculty unionization in higher education after having participated in both roles?

2. What are the administrators' perceptions of the factors of unionization and collective bargaining with regard to the interpersonal relationship between faculty and administration?

Many psychological and sociological theories attribute individual and/or group behavior to a single attribute or to a relationship between variables over which the group or the individual may or may not have control and which may or may not be intentional. When looking at the perceptions that administrators who work in institutions of higher education have toward faculty unionism and the collective bargaining process, this researcher examined the individual perceptions of these administrators who have worked with a unionized faculty body and who have directly participated in the collective 
bargaining process. Sociological theories allow for the recognition that although the actual experience may be the same for the different individuals and parties involved in a particular situation, the perceptions of each of those seated at the table will be unique.

Symbolic interactionism recognizes the unique perspective of the individual, the impact of social interactions on the individuals involved and the groups involved, and the role of intentionality (Blumer, 1969; Mead, 1934). The relationship, object, or concept and the symbolism or meaning of such is determined by what an individual pays attention to by choice and has no meaning on its own. Instead, it is the individual that assigns the meaning based upon what that individual knows about his or her world at a given time and within a given context. It is this individual's selection and interpretation of a symbol/stimulus that, in turn, results in the course of action that individual will take. In order to best understand why a person may have chosen a particular course of action, it is therefore important to look at the individual's process of selection, definition and interpretation when attempting to understand that individual's perception of a given event (Stryker, 1980). In the case of this study, those events included working with unionized faculty members and participating in the collective bargaining process.

Mead (1934), the earliest pioneer of the new schools of sociology in understanding that it is the individual who brings meaning to an object as an active agent rather than being tied to a particular behavior based upon particular events or stimuli, differentiated between the "I" and the "Me". The "I" is that part of an individual that brings the initial impulsiveness to the process of symbolic interactionism. It is the "Me" that brings all of the expectations of others to the process. It is the combination of both, according to Blumer (1969), which determines what it is that one will pay attention to 
based on the meaning that symbolism has for that individual. The consequential action that one will take is based on this meaning. The social interaction piece of the interpretative process affords the individual the opportunity to select, check, regroup, suspend, or transform the meaning of an event or symbol. At times, the symbol or concept will hold the same meaning or perception for all involved allowing for understanding to take place. If there is confusion or different perspectives related to the symbol or concept, there may then be miscommunication resulting in chaos or inaction (Stryker, 1980). It is imperative that one understands that each actor has a unique perspective related to the symbol or concept or action. That perspective contributes to the action that person will take, which may in turn result in harmony or discourse in relation to others who may be participating in the same event but paying attention to different symbols, or concepts or assigning different meanings to the same symbolism or concepts. This difference in perspective and meaning often results in poor communication between the parties.

Symbolic interactionism was the theoretical framework that guided the interviewing process. Lending itself to the qualitative research design, symbolic interactionism allowed for the realization that individuals have different perspectives through which they view their situations and world. Using symbolic interactionism as a framework for the formatting of the study questions, the questions sought to explore the individual participant's direct experiences, thoughts and feelings, as well as past experiences related to these current experiences and perceptions. 


\section{Summary of Literature Review}

As discussed in this chapter, the purpose of this study was to gain a better understanding of the perspective of the higher education administrator related to what it is like to work with unionized faculty members, to participate in the collective bargaining process, and the effects of unionization on all of those involved to better understand the role unionization and collective bargaining in higher education has played in the lives of higher education faculty and administrators for almost 50 years.

Chapter 2 provided a brief analysis of the history of faculty unionization and collective bargaining in higher education in the United States beginning with the contextual factors that favored bargaining, including the favorable economic conditions following World War II and the call for social equity in the U.S in the early 1960s. In addition, some of the legal issues and legislation related to bargaining and unionization in the U.S. and in the higher education academy were discussed beginning with the National Labor Relations Act of 1935, which offered mandated administrative participation in bargaining and offered employee protection while becoming unionized and bargaining. The Yeshiva case, perhaps the one court case that has impacted the relationship between faculty and administrators the greatest, drawing a clear delineation between the faculty role and the administrative role in private institutions of higher education in the U.S., was also discussed.

While there has been a decrease in participation in the private sector of higher education, unionization and collective bargaining continues to play an active role in public institutes of higher education. Many of the current administrators in higher education have seen dramatic changes relating to the missions of the higher education 
institutes, which have in many cases called for an increased bureaucratic structuring of those systems. In addition, there has been an increase in the involvement of many external constituents, perhaps the most prominent of which has been the Supreme Court.

Recent trends indicate an increase in the degree of outside involvement in collective bargaining in higher education, most notably through the National Labor Relations Board, the courts, and the State Public Employee Relations Board (Abraham \& Voos, 2005; Cohen, Walsh, \& Biddle, 2008; Kaplin \& Lee, 1995; Saltzman, 1998). These trends appear to support the early projections of those academicians who predicted that faculty unionization and collective bargaining in institutes of higher education based on the industrial model would lead to conflict between internal constituents in the organization related to power and resources and the dissolution of communication between faculty and administration (Birnbaum, 1980; DelFavero, 2003). There is a limited amount of research available that focuses on the administrative perspective of faculty unionization and the collective bargaining process in today's institutes of higher education. Many of these earlier publications were based on conjecture as they were published when relatively little was known about the effects of faculty unionization and collective bargaining in higher education.

Others argue that from a social exchange theoretical perspective in order to maintain a positive relationship between faculty and administration and for collective bargaining to be successful, both sides must gain something from the relationship and resulting interactions (Aselage \& Eisenberger, 2003; Fuller, Hester, Barnett, Frey, \& Relyea, 2006). While the literature supports that unionization has assisted faculty members in bringing about higher salaries, a decrease in salary disparities between sexes 
and among academic units, job security, enhanced employee benefits, and increased levels of employee satisfaction, there has been little written about the benefits of faculty unionization and collective bargaining for the higher education administrator (Ashraf, 1997; Benedict, 1999; Benedict \& Wilder, 1990; Castro, 2000).

A qualitative study using a case study approach based on symbolic interactionism was used in an effort to gain firsthand knowledge of what it is like to be a higher education administrator working with unionized faculty members and participating in the negotiation process. Symbolic interactionism recognizes the role of the unique perspective of the individual and the process leading to the formation of that perspective as being a continuous, evolving, contextual process that will, in turn, influence individual behavior and group dynamics. 


\section{CHAPTER III}

\section{METHODS}

The purpose of this study was to add information to the existing body of literature related to higher education by identifying some of the contemporary themes and concepts related to faculty unionization and the collective bargaining process, and the resulting dynamics in terms of the interpersonal relationships between faculty and administrators from what Bogdan and Biklen refer to as the native's point of view (Bogdan \& Biklen, 2007). In this study, the native's point of view was that of the higher education administrator who has worked with unionized faculty members and participated in collective bargaining. From a constructivist conceptual orientation, the theory of symbolic interactionism recognizes that human beings are active agents in creating their perceptions, reactions, and resulting purposeful behaviors based upon their personal interpretation of events and interactions with others (Bogdan \& Biklen, 2007; Fraenkel \& Wallen, 2003; Rocco, 2003). One's unique perspective and the resulting interpretation of a specific phenomenon is not only intentional, it is also aided by one's definition of self (Blumer, 1969). This definition of self is created through the interaction and interpretation of such with others including noted gestures, actions, symbols, and language. This process of defining one's self is dynamic as one continuously learns more about the self through recurrent interactions with others (Mead, 1934).

This investigation took place initially by conducting face to face interviews with all nine of the study participants. Subsequent face to face or phone interviews with the participating higher education administrators allowed for follow-up and any needed clarification related to the data obtained. The data was continuously analyzed during the 
data collection phase of the study. Initially the key words related to the study questions were highlighted on each of the typed transcripts. Once all of the data was obtained and transcribed from all nine of the study participants the researcher continued to review the transcripts and to listen to the audiotapes over a period of a few months. A preliminary analysis was then preformed looking for similarities and differences within and between the reported findings. The researcher then turned to the literature related to the study questions and the study findings before naming five descriptive themes.

All of the study participants experienced firsthand participation in collective bargaining sessions and workplace relationships with unionized faculty members. It was my intention to gain an in depth understanding of what it is like to be an administrator working with unionized faculty members while participating in the collective bargaining process in the urban, multi-campus college and university settings, and then to report that information to the reader. This section includes a description of the research design that was used, a depiction of the role of the researcher, an account of the study sites and the participant selection process, and the procedures in the collection, management, and analysis of all of the study data for this research paper concerning the administrative perspective of unionization and bargaining in the selected public institutions of higher education in southern Florida.

\section{Research Design}

The use of a qualitative case study approach allowed for an in depth exploration and analysis of the multiple realities of the participants interviewed for this study (Bogdan \& Biklen, 2007). In the instances of working with unionized faculty members and participating in the collective bargaining process, this researcher was able to find a 
limited amount of research available that was written from the perspectives of those college and university administrators who have directly participated with these conditions and events. The qualitative case study design is most appropriate when one seeks to gain new knowledge related to a particular phenomenon within a defined context from a particular group of people who have experienced or participated in the particular event or situation that is being studied (Fraenkel \& Wallen, 2003).

The case study approach, as described by Bogdan and Biklen (2007), characterizes the use of individual and group situations and perceptions related to a specific organizational activity. The case study approach was used as it assists the researcher who seeks to communicate to the reader information that describes what it was like to be this individual in a given context experiencing a particular situation (Weiss, 1994). Stake wrote about the practicality of the intrinsic case study design in that it is applicable when the researcher is interested in learning about a particular phenomenon about which little is known by gathering firsthand information from those who have experienced that phenomenon (Stake, 2005). The use of the intrinsic case study method in this study, as described by Stake (as cited in Fraenkel \& Wallen,2003), afforded this researcher the opportunity to understand collective bargaining from the perspectives of those administrators who were interviewed and had a firsthand knowledge of working with unionized faculty members, the collective bargaining process, and the factors of bargaining related to interpersonal relationships between faculty members and administrators on their campuses. 


\section{Role of the Researcher}

The motivation for this study came from this researcher's personal and professional desire to gain insight and understanding into the phenomenon of unionization and collective bargaining from the viewpoint of the experienced higher education administrator. Being relatively new to higher education after working in the healthcare industry for close to 25 years, I was fascinated when after I joined the union, a nurse educator professional colleague asked if I thought that was really a good move to make before obtaining tenure. After all, he was quick to point out, administration is opposed to faculty unionization and collective bargaining, as well as to the granting of tenure. He went on to add that I might just be giving them the ammunition that they need so that they would not have to grant me tenure after three years. Others in the department were quick to agree. The unspoken rule was that you had a much better chance of obtaining tenure if you stayed off the radar screen. I was told that one did so by not joining the union or becoming involved in any union related activities. I asked colleagues from other disciplines/departments if they agreed that it may not be in one's best interest to join the union as a new faculty member and the majority agreed that it would be better to do so only after obtaining tenure because the administration was opposed to faculty unionization and collective bargaining. No one was able to substantiate this claim though. When I asked colleagues why they thought this to be true, most simply replied that this was just common sense.

In contrast to quantitative research, qualitative research assumes some level of researcher involvement in recognizing that it is impossible to separate those who participate in the study from the context in which the study takes place. The researcher 
was a part of this context and brought his or her lived experiences to the study (Bogdan \& Biklen, 2007; Fraenkel \& Wallen, 2003; LeCompte, 2000). This realization brought about the need for the researcher to recognize the resulting personal beliefs and biases and to make the reader aware of them as they will have some level of impact on the types of questions asked, as well as the theoretical framework used to guide and interpret the study findings. Bogdan and Biklen (2007) urged the researcher to recognize that one cannot separate one's self from past experiences and the resulting personal beliefs and values while involved in the research process. Instead, they urged the researcher to remain reflective throughout the research process recognizing that the goal is to not only to recognize that the researcher is a partner in the study, bringing in experiences that will enrich the study, but to also recognize that each participant is a partner. By interacting with and listening to each participant, the study researcher was afforded the opportunity to learn and grow.

A third generation Irish-American, who was raised in a highly industrialized area in upstate New York where the majority of local residents worked in the steel mills, on the docks, in the auto industry, and in public service types of jobs, I often heard the word "union." Not only were labor unions a topic of discussion in our house, they were also a source of family pride. Surrounded by family members and neighbors employed as steel workers, brick layers, fire fighters and police officers, I learned at an early age that unions were hard won and needed to be protected at every cost.

My educational background includes having earned an Associate Degree in Nursing, a Bachelor's Degree in Psychology, a Master's Degree in Nursing, and the completion of all coursework leading to an Educational Doctorate in Higher Education 
Administration. After graduating from a 2-year college in 1977, I worked as a bedside nurse, nursing supervisor, community college faculty member, and as a college administrator in the role of Academic Associate Dean for Nursing. Thirty-four years of work experience as a nurse has provided me with numerous opportunities to conduct interviews with patients and families from a vast variety of backgrounds.

These experiences have led to the ability to recognize and understand the uniqueness of each person's story while realizing how one's unique perspective contributes to one's individual behavior on the health-illness continuum. In addition, my experience with each patient as a member of a family and community has led me to formulate a personal belief that each person's perspective is based on past experiences and relationships. Last, recognizing the inherent value of each individual, this researcher's nursing experiences have necessitated the need to enter into a collaborative partnership with each patient and family encountered. The forming of these collaborative relationships with patients and families necessitated the recognition of the existence of the many interdependent caring relationships and beliefs inherent to the individual patient in order to best understand the complexities of health and illness as perceived by that patient.

These life experiences as a child, student, nurse, college faculty member and administrator, as well as all of the relationships encountered in each of these roles, all contribute to what I brought to the study as the researcher. Each study participant was valued as a partner in the study process while I made a conscientious effort to assume each of the primary roles recognized as essential for the qualitative researcher by Weiss (1994). Weiss encouraged the researcher to enter into a partnering relationship with study 
participants and offered five primary roles for the researcher. First, the researcher must recognize that the project necessitates that the researcher can only gain useful information by entering into a partnership with each study participant. Second, it is the responsibility of the researcher to clearly delineate the areas to be explored while remaining sensitive to the quality of the terrain and making any necessary changes as each interview progresses. Next, the researcher must accept the privileged relationship that affords an opportunity to seek information from each participant that he or she would not make available to anyone else and to accept the responsibility of not asking frivolous questions. Along with this responsibility comes the fourth role, which is to honor the integrity of all participants as demonstrated by not questioning the participants' motives, choices, or appraisals. Last, the role of the researcher is to do no harm and to hold the personal identity of the participant confidential.

Serving in the role of associate dean at a community college for five years afforded me the opportunity to recognize and have access to administrators from different institutions, who have worked with unionized faculty members and actively participated in negotiation sessions. Working in the administrative role of Associate Dean (equivalent to Department Chair), while not being high up in the pecking order of the higher education arena, also placed this researcher in a non-threatening position when interviewing higher level administrators. Additionally, my role as a graduate student not only granted me the opportunity to do the study, but also provided me the chance to work with a committee of scholars offering the constructive criticism that was needed while embarking on this academic endeavor. 


\section{Site and Participant Selection}

This study was about faculty unionization and collective bargaining in the university and college (formerly referred to as community college) settings in south Florida. These settings were chosen in an attempt to look at the perspectives of those higher education administrators who (a) share in the same collective bargaining representation unit (United Faculty of Florida) for faculty members, (b) are regulated by the same state laws regulating collective bargaining, and (c) share the same state regulations as related to unionization and collective bargaining including the process, permissibility of bargaining topics and grievance procedures. Time and financial constraints were also considered and factored into the site location decision.

The bargaining unit for faculty members at these college and universities in the southeast section of Florida is The United Faculty of Florida (www.unitedfacultyofflorida.org). The United Faculty of Florida (UFF) is the bargaining agent representing faculty members at $32 \%$ of the community colleges in Florida. The UFF represents faculty members from 11 Florida state universities, 11 Florida colleges (formerly called community colleges), and three independent universities based in Florida, as well as graduate assistants from three of the aforementioned Florida state universities. There are a president and vice president of UFF, along with four Bargaining Council Vice Presidents. In addition, each of the colleges and universities represented has its own faculty elected union chapter president.

Although all faculty members receive all of the benefits covered under the collective bargaining agreement, not all of them pay union dues. The payment of such is voluntary. State legislation concerning collective bargaining for employees in the state of 
Florida initially came into being in 1943 with the amendment of the Florida Constitution. In 1946, the Florida Supreme Court interpreted the 1943 amendment as not giving public employees the right to bargain collectively, picket or strike. It was not until 1969 that the Florida Supreme Court upheld a new constitutional provision guaranteeing the rights of public employees to bargain collectively. The right to work section of the constitution was revised in 1968, thereby giving the public sector employee the right to work whether or not they joined the union representing the employees in the place of employment (Public Employees Relation Commission, 2004). Prior to the passing of this legislation, employees could be fired or refused hire if they did not pay dues by a specified date as determined by the union representing labor at each institution.

For purposes of this study, administrators were defined as those persons who have direct, participatory experience working with unionized faculty members and participating in the collective bargaining process, but are not entitled to representation protection by the faculty union by virtue of their administrative responsibilities and institutional allegiances. Although there is no specific state or federal law banning administrators from union protection while bargaining collectively in the public sector, the precedent has been set that administrators in both the private and the public sectors of higher education are not afforded federal or state protection while doing so. The case that has been most influential in the setting of this precedent through the interpretation of the Supreme Court is the Yeshiva case (Metchick \& Singh, 2004). To date, there is no collective bargaining unit for administrators working in institutions of higher education in south Florida. Academic administrators at these colleges and universities include, but are 
not limited to, the college president, the vice president, the provosts, the academic deans, and all of the related associate deans and/or department chairs.

Study participants were recruited from two colleges and two state universities in Florida. These institutions are similar in that they are all multi-campus, urban, public institutions that serve a culturally, racially, and ethnically diverse student population. All of these institutions also have a board of trustees that is appointed by the governor of the state. The institutions differ in their focus as related to research and accessibility, as well as faculty credentialing requirements. Although the overall general descriptions of these contexts remained the same throughout this dissertation, the names and identities of the study participants and these institutions were not disclosed.

The sample for this study included a small, purposive sample of nine higher education administrators who have worked with unionized faculty members and represented administration at the bargaining table during negotiations. Recognizing that there is no prescriptive number for the number of subjects needed when working on a qualitative study, the exact number of participants was determined as the study progressed, recognizing the need to be as representative as possible by adding typical cases, deviant cases, and cases that allow for maximum variation in both participant and site wherever possible (Seidman, 2006). Purposive sampling was used to assure the researcher, as well as the reader that those persons interviewed have the necessary knowledge and experience with faculty unionization and collective bargaining. Recognizing the need to represent as much diversity as possible in the attitudes and experiences of the different administrators from institutions of higher education, a 
conscientious effort was made to include some variation as related to gender, age, culture, ethnicity, and type of institutional affiliation when selecting participants.

The majority of study candidates were identified through the personal knowledge of this researcher, an administrator at a local college and a graduate student at a university where collective bargaining occurs. In addition, additional study participants were identified and interviewed based upon recommendations from two of the study participants. This method of referral and inclusion is what is referred to in the qualitative study literature as the snowball effect (Fraenkel \& Wallen, 2003; Seidman, 2006). Candidates were selected based on their experience as participants in the collective bargaining process as administrators and their willingness and ability to communicate their experiences, attitudes and beliefs related to collective bargaining and faculty unionization. Seidman (2006) recommends the use of negative cases in a qualitative study. Negative cases include administrators who have not participated in collective bargaining sessions. While there is much to be learned from participants who are considered negative cases, described in this study as those participants who are administrators who have not participated in the collective bargaining process, time constraints did not allow for such. This is, however, one of the suggestions for future research as related to the administrative perception of collective bargaining and faculty unionization.

For the convenience of the study participants, all of the interviews with the study participants were conducted at mutually agreed upon locations close to their campuses. All of the participants were initially contacted by phone by the researcher who explained the study and the study design, asked the participants if they would be willing to 
participate in the study, and then to mutually determine the interview time, place, and date. All of the candidates approached agreed to participate in the study.

Realizing the importance and significance of this initial contact, it was important that a clear and concise description was provided to each potential study candidate including a brief introduction of myself as the researcher, my institutional affiliation, what this researcher was trying to understand, why the candidate was chosen, and a brief summary of the data collection, management and analytical techniques that were to be used regarding the confidentiality of the participant's identity at all times (Bogdan \& Biklen, 2007). Once the initial contact was made, a follow-up letter was sent to each participant who agreed to participate confirming all of the information discussed during the initial phone contact. Information provided included the date, time, and location where the interview was to take place, as well as contact information for the researcher and Dr. Benjamin Baez, the Dissertation Chair for this study.

Higher education administrators who participated in this study included five female and four male participants, who have been in their current positions for an average of 5.4 years. The administrators interviewed for this study have been employed in the higher education arena for an average of 27.2 years. The average age range of the study participants was 50-59 years, with the youngest being 40-49 years of age and the oldest being 60-69. All but one of the administrators interviewed had doctorate degrees. At the time of their participation in bargaining as discussed in this study, one of the participants served as president, one as vice presidents, two as provosts, four as academic deans, and one as department chair. 


\section{Data Collection and Management}

Symbolic interactionism calls for an understanding that all human experiences are actively chosen and interpreted uniquely by each individual. It is the interpretation of an event based upon one's relationships and experiences with others that aids in the determination of one's perspective and resulting behavior while participating in that event (Blumer, 1969). In order to best understand how one interprets an event or a phenomenon, the researcher must gain insight into the participant's experiences, relationships, and thought processes preceding that interpretation (Blumer, 1969; Bogdan \& Biklen, 2007). Symbolic interactionism also recognizes that the self is defined through interacting with others while coming to see one's self as others do (Mead, 1934). These basic tenets of symbolic interactionism were taken into account when formulating the interview guide, interviewing the participants and analyzing the study data.

The primary method of data collection was semi-structured face to face interviews and phone interviews. All of the initial interviews with each participant were conducted face to face and were audio recorded with the permission of each of the participants. The participant was afforded the opportunity to conduct a second interview either face to face or via phone if necessary and/or desired by the participant or researcher. A modified analytic induction approach to data collection and analysis was employed as it allowed for the simultaneous collection and analysis of data affording the researcher the opportunity to modify, add, or delete questions if necessary with each progressive interview (Bogdan \& Biklen, 2007). This method of data collection is recommended when there is not much written about a particular experience and the researcher has a desire to learn more about this experience (Bogdan \& Biklen, 2007). 
Seidman (2006) recommends a three interview schedule with each participant, each interview lasting for approximately 90 minutes, occurring 3-7 days apart. The spacing of the interviews allows for participant reflection as well as flexibility should the participant experience any type of an unanticipated situation, which may impact the ability to participate fully in the interview including illness and scheduling conflicts. Recognizing the time constraints that face higher education administrators, a modified version of Seidman's interviewing schedule was used. Each participant was asked to participate in a set of two interviews, each lasting for about one hour. Seidman (2006) and Weiss (1994) stated that while they recommend that an interview last for about 90 minutes, this is not a well-researched limitation. Instead, they state that what is important is that the researcher allows the participant ample time to reflect and discuss the phenomenon under study while continuing on with the interview only as long as the process is productive.

Interviews were conducted with the assistance of an interview guide. Utilizing what Weiss (1994) refers to as a diachronic style of formatting, the researcher introduced broad, open-ended questions relating to different periods in the participant's life proceeding from what he refers to as the beginning to the end (see Appendix A). In the case of this study, the progression included the time span before the participant participated in the collective bargaining process, moving forward to the period of time when the participant actually participated in the bargaining sessions and then ending with a period of reflection and speculation about the collective bargaining process and faculty unionization in the higher education arena. Working from the theoretical orientation of symbolic interactionism, the guide focused on the participants' experiences, thoughts, as 
well as related feelings and actions. The guide also included a section for the researcher that contained useful probes or leads should the researcher experience a time during the interview process where such aid could be needed.

In an attempt to develop a rapport with each participant, each initial interview began with a short period of socialization (Bogdan \& Biklen, 2007). The potential risks and benefits of participating in the study and the purpose of the study were discussed. All of the candidates were given the contact information for both me and my dissertation chair. They were advised that they could contact me or the dissertation chair at any time should they have any questions and/or concerns related to the study. All contact information was provided for both, including phone numbers, email addresses, and formal mailing addresses. All participants were assured that they could choose to stop the interview at any time with or without explanation. During the first interview, each study participant was asked to address any questions that he/she might have about the study. None of the candidates had any questions and none of the candidates asked to stop the interviews. Each participant was offered a copy of the consent. One of the candidates requested such. A brief discussion also took place reassuring each participant that their names and locations would be changed in the final dissertation to protect their confidentiality. A brief acknowledgement as to why that particular participant candidate was chosen was also reviewed. Before soliciting study participants, in an effort to assure the safety and the rights of all study participants, Institutional Review Board (IRB) approval was secured.

The remainder of the first interview was spent, in part, focusing on the participant's life experiences and related thoughts and feelings including professional 
relationships related to their participation in collective bargaining sessions and working with unionized faculty members. A second reflective shift was then made affording the participant an opportunity to reflect upon future plans and ideas related to his or her administrative role and participation in the collective bargaining process, the relationships between that administrator and faculty members and other administrators, as well as lessons learned. Weiss (1994) suggested that no more than 3-4 transitions be made during any one interview in an effort to keep the respondent focused on the concrete details of the specific phenomenon under study and that each transition be clearly introduced. A second interview was done to provide the researcher with the opportunity to follow up on, to seek clarification, or to ask the participant to expand upon any material that was previously discussed or may have been overlooked in the first interview relevant to collective bargaining and faculty unionization.

The first interview was semi-structured. Questions for reflection were adopted utilizing a hypothetical, a devil's advocate, an ideal position and/or an interpretative type of stance (Merriam, 1998). The hypothetical question posed a situation and then asked for an opinion. The question used asked the participant, "If I am new to higher education administration and asked to participate in negotiations, what do I need to know?" A devil's advocate type of question was also asked. After stating that some faculty members are hesitant to participate in collective bargaining because of a fear of what their administrative team might think of them, I asked, "What would you say to these faculty members?" The ideal position question was used to realize what it is that the participant thinks is necessary to work with unionized faculty members. I asked the participants, "Being new to higher education administration, in order to be successful working with 
unionized faculty members, what is it that I need to know?" Last, the interpretive question used sought to gain a better understanding of the administrative perception of the level of ease or difficulty in working with unionized faculty members versus nonunionized members. I asked, "Do you think that it is more difficult or less difficult to work with unionized faculty members?"

In addition, during this phase of the study the participants were asked if there was anything else that they wanted to share with the researcher about working with unionized faculty members, having participated in the collective bargaining process, the impact of unionization and participation in collective bargaining on interpersonal relationships and/or unionization, and negotiations in general. Upon completion of the interviewing process with each participant, Weiss (1994) recommends that a gentle lead be given to the participant informing him or her that the interviewing process is coming to an end. His recommendation is to make a brief statement declaring such and then end with the questions related to the participant's demographic profile. The interviews in this study concluded with the solicitation of demographic information from each participant. The demographic information that was solicited included professional title, number of years in higher education, number of years as a faculty member in higher education, number of years as an administrator in higher education, number of years in current position, current age group, highest degree received, and information related to past union affiliations (see Appendix C).

\section{Data Analysis}

Study participants were interviewed and data was analyzed continuously and simultaneously during the data collection phase of the study. This modified, analytic, 
inductive approach allowed the researcher to reflect on the study questions while making any needed revisions and afforded her the opportunity to form rough sketches of what was being indicated in the obtained data related to the phenomenon under study as recommended by Bogdan and Biklen (2007).

Upon the completion of each interview, the researcher listened to the taped audio recording of the interview several times while making notes each time that included any questions that required follow up or the need to formulate new questions for subsequent interviews. Once the interview for each participant was completed, the researcher, in an effort to further immerse herself in the data and to protect the confidentiality of the administrative participants, transcribed all of the audio taped interview data for that participant to a Word file. To further enhance the confidentiality of the study participants, the tapes do not contain the study participant's name or institutional affiliation. Instead, each participant was assigned a pseudonym. The assigned pseudonym was used as an identification measure on each of the participant's audio tapes and in Chapter 4 in the section labeled participant profile. A separate list containing each participant's name and assigned pseudonym was kept by the researcher should it be necessary to clarify or verify any gained information as related to the study so that any information related to the discussed study findings could be confirmed or clarified by the committee members as needed. All information related to the participant and the coding of the data has been kept in a locked file in the investigator's home. Notes were added to the transcriptions related to any nonverbal communication that took place during the interviews, as well as any notes related to the context or any other data that seemed pertinent to the study. Once all of the data was transcribed and additional notes were added as needed, a folder was 
assigned to each participant, in both hard copy and as a computer file. These files contain a pseudonym related to each participant. The participant's name or any other identifying information does not appear anywhere in these folders.

In an effort to make sense of all the information obtained from the study participants as related to the study questions, seeking to gain a better understanding of the administrative perception of faculty unionization and collective bargaining and the factors of such in regard to the interpersonal relationships between faculty and administration, the process of data analysis was performed during and after each of the nine interviews, as well as several times between interviews and at the conclusion of the last interview.

Data analysis entailed the gathering and organizing of all of the researcher's notes and interviews, sorting the data into smaller units based on similarities and differences while searching for descriptive thematic categories based upon the study results and the available existing literature related to the topic under investigation, and then synthesizing the units while looking for descriptive themes to explain the phenomenon under study (Bogdan \& Biklen, 2007). During this phase of the study, it was important for the researcher to keep in mind that her primary responsibility was to represent the study participants, which is different from identifying with the participant or endorsing everything that the participant says (Miles \& Huberman, 1994). The descriptive thematic categories that were identified were based on the information obtained from the study participants. The themes offered a way to cluster the information that was interconnected, organizing it in a way that represented the ideas and perception of the study participants 
while presenting coherent patterns and the structure needed for the presentation of the findings (Bogdan \& Biklen, 2007).

There are several computer software programs available to aid the investigator with qualitative data analysis. While this researcher did consider using a software program to assist in the data analysis of the obtained study data after realizing that those experienced researchers who have used the software cautioned that while the programs offer some degree of assistance in the analytic process, they are limited as to the possibilities of the themes, metathemes or theories that they might identify from the existing data (Barry, 1998; Bogdan \& Biklen, 2007; Merriam, 1998; Miles \& Huberman, 1994). The researcher must therefore continue the analytic investigation in order to unlock any new information that may have been overlooked by the software.

While there are many benefits to using the computer software, such as the ability to readily categorize all related information obtained from the interviews in a timely manner, it is important for this researcher to be continuously submerged in the study through the continual listening, reading, and re-reading of the material gained from the study interviews to aid in a more comprehensive analysis and categorization of the study findings as reported by the participants. For purposes of this study, data analysis was not done through the use of a computer program. The only computer assistance utilized was Microsoft Word for the transcription and reporting of all study findings.

Although the data was informally analyzed by the researcher throughout the study, the final analysis did not begin until all of the data had been collected, read, and reread while searching for any similarities and differences between interviews. Once each interview was completed and all of the data was transcribed by this researcher, field 
notes, thoughts, and observations were added. Several copies of each transcript were made. Upon the completion of each interview the researcher listened to the taped audio recording of the interview several times and then transcribed all of the information from the audiotape into a Word file. Data collection and analysis was performed concurrently. Once the transcription was reviewed for accuracy, it was reviewed several times. Any participant responses that most strongly addressed the concerns of the study as indicated by the study questions and the theory of symbolic interactionism were then highlighted. Once all of the interviews were completed, with all of the transcripts in hand, the researcher then compared the transcripts while noting any similarities and differences in the highlighted key phrases, quotes, and applicable descriptive notes that the researcher wrote in the outer margins on the study transcripts.

The process of data display and data reduction was begun after a thorough and repeated review of all of the study information and the available literature related to unionization, collective bargaining and the factors of each in the relationships between faculty and administrators. Utilizing a modified concept mapping approach (Schuster, 2008) the research questions were written on large, yellow sticky notes and placed in the middle of a wall in this researcher's home. Initially, a total of nine descriptive categorical themes that were identified by the researcher after immersing reviewing the study questions and the information from all nine of the study participants over the course of several months, were written on smaller sticky notes and placed around the study questions on the wall in the researcher's home. The highlighted quotes from the study participants were then cut from the transcripts and placed under applicable descriptive theme. These initial thematic categories included the road to and the reasons for entering 
higher education administration, reasons for participating in bargaining, feelings related to bargaining and the process, feelings related to faculty unionization, preparation for bargaining, a discussion of a typical bargaining session, life and professional experiences that may have influenced one's perceptions of working with unionized faculty members and actively participating in negotiations, and the subjective experience of the effect of unionization and bargaining on the faculty-administrator relationship and the higher education academy in general.

The researcher continued to revise the categorical themes and the related literature over the next few months. Finally, the descriptive categorical themes and all supporting information were studied in relationship to the proposed study questions. Upon the completion of this phase of the data analysis, once again, this researcher returned to the literature in a final attempt to tie all of the data gathered together with the related information from the literature in a comprehensive, explanatory style. The final thematic descriptions focused on the administrative negotiator and the needed background experience, negotiation preparation, the role of the administrator in bargaining, decentralized bargaining in Florida's higher education institutions, and the public higher education sector collective bargaining process in Florida.

After focusing on research question number one concerning the administrators' perceptions of the collective bargaining process and faculty unionization in higher education after having participated in both roles, one example of the evolutionary process from the initial categorization of the data from the written transcripts to the coding of each thematic theme can be seen in finding number two - collective bargaining/negotiations and the administrative preparation for such. Initial codes that 
were placed in this categorical finding included reasons for participating in bargaining, feelings related to bargaining and the process, a discussion of a typical bargaining session, and life and professional experiences that may have influenced one's perceptions of what it was like to have actively participated in negotiations with faculty union representatives.

Finally, this researcher then proceeded to answer what Rocco (2003) describes as the overall study question, "So what?" In conjunction with the dissertation chair, committee and found literature, the researcher discussed the implications of the study findings along with recommendations for higher education practice related to working with unionized faculty members, participating in union negotiations as an administrative representative, and collective bargaining in Florida's higher education system. Suggestions were also put forth for further research based on this study and the resulting findings in Chapter 5.

\section{Credibility of Study Findings}

The usefulness of the study findings is determined by the credibility of the data collection tool (Fraenkel \& Wallen, 2003). The researcher must, however, make visible all of the steps in the data collection, management and analytic phases of the study and be clear at all times that the job of the researcher is to make the voices of the participants known (Seidman, 2006). Bogdan and Biklen (2007) recommend the recording of field notes in addition to the audio recordings when interviewing participants in an effort to transcribe and recognize any thoughts and feelings the researcher may have while obtaining data from the field. These notes were made available to the dissertation chair and reflected upon by the researcher during all phases of data collection and 
management. In addition, the researcher must share his or her background and the theoretical framework used to assist the reader/practitioner in realizing more about the collection and analysis of the data at hand (Bogdan \& Biklen, 2007). The study findings in the next chapter will include paraphrased quotes from the participant under each stated thematic category so that the reader can trace how the researcher reached the said stated conclusions.

The data collection technique employed in this study was semi-structured interviews, although an interview guide was used by the researcher. The guide listed broad categories to explore with each participant (see Appendix A). Although some amount of researcher bias and affect is inevitable, several strategies were employed in an effort to minimize such. Specific strategies that were used by this researcher to enhance the credibility of the study included triangulation, member checking, and the use of a broader context that included participants from both the community college and the university settings. Bogdan and Biklen (2007) stated that one method of triangulation involves the use of multiple theoretical perspectives when analyzing data. Because the researcher is a graduate student, her analyzed data and the process of arriving at the analysis was reviewed by her committee members as requested. Each of these members, looking through the lens of their own personal and professional perspectives and based upon his or her life experiences, offered a variety of theoretical orientations. In addition, any interpretative data was reviewed with the committee chair as requested, as well as with the study participants as deemed necessary.

The opportunity to interview each study participant a second time afforded the researcher a chance to follow up and to seek clarification as needed with any data 
obtained from the participant, a simple version of member checking (Seidman, 2006). A third strategy that was employed in an effort to reduce researcher bias included the use of broadening the case (Bogdan \& Biklen, 2007; Weiss, 1994). In the case of this study, the context was broadened to include administrators from community college and university settings in an effort to look for similarities, as well as variation not only within groups but also between the groups.

Finally, some practical considerations when attempting to maximize study reliability were implemented. The first was the conscientious effort on the behalf of the researcher to keep the participant focused on the phenomenon at hand while asking for concrete descriptions of the event, others involved, and related thoughts and feelings (Weiss, 1994). Next, the researcher listened for what Seidman (2006) referred to as the outer voice. This is the voice that may include words such as challenging or resourceful. These politically charged words are often used by one when speaking with the public about obstacles, blocks, and uncomfortable situations. When the participant engaged in the use of the public voice, the researcher gently probed further or requested a story related to a particular event, relationship, or feeling in an effort to gain a more insightful explanation. Third, in an effort to gain in depth, comprehensible material from the participant, the researcher should be direct and use past tense when asking the participant about a particular incident or event or feeling (Seidman, 2006; Weiss, 1994). Last, recognition of the researcher as a study instrument that is sympathetic, perceptive, flexible, and smart can be used to one's advantage while conducting a qualitative inquiry as all of these traits can contribute to a more comprehensive interview and analysis. 
(Seidman, 2006). I possess these attributes after many years in nursing and education and I displayed them while interviewing my colleagues.

$$
\text { Summary of Study Methods }
$$

Higher education administrators are active participants in union negotiations while working and interacting with unionized faculty members on a daily basis. Therefore, they have an impact on the future of faculty unionization and collective bargaining. In accordance with the theory of symbolic interactionism, it is crucial that we understand the relationships, experiences, and related perceptions of these administrators after participating in the negotiations process with unionized faculty members as these perceptions will then aid the reader in understanding the complexities involved and the behaviors displayed by the higher education administrators interviewed.

The study method adopted for this study utilizing a case study approach involving an initial face to face interview and then a subsequent face to face or phone interview was discussed in this chapter. A brief history of the researcher was included as it related to the role of the researcher, the subject of interest, the understanding of the perceptions of higher education administrators related to collective bargaining and faculty unionization, and in the data collection and analysis phases of this qualitative study.

Nine higher education administrators, who had worked with unionized faculty members and who had directly participated in bargaining, were chosen from two universities and two community colleges located in south Florida for this study. The intention of the semi-structured interviews with each of the study participants was to gain a comprehensive understanding of their experience and perspective of the collective bargaining process, working with unionized higher education faculty members, and their 
perspectives of the effect of unionization and collective bargaining on the interpersonal relationship between faculty and administration. 


\section{CHAPTER IV}

\section{FINDINGS: PROFILES AND DESCRIPTIVE CATEGORIES}

The intended purpose of this multi-case qualitative study was to explore the experiences, beliefs and attitudes related to faculty unionization and the collective bargaining process from the perspectives of nine contemporary higher education administrators, who have direct knowledge and experience working with and participating in such. In particular, the research questions that guided this study focused on the administrators' perceptions of the collective bargaining process and faculty unionization in higher education after having participated in both roles and their perceptions of the factors of unionization and collective bargaining with regard to the interpersonal relationship between faculty and administration.

Guided by these research questions, as well as the theory of symbolic interactionism, the knowledge gained from this study will allow university and college administrators to proceed with participating in the bargaining process and working with unionized faculty members with a clearer understanding of their roles, their personal philosophical beliefs about faculty unionization, and the dilemmas and duties inherent in such based on their roles, interactions, and experiences while negotiating and working with unionized faculty members. The meaning of these practices or events, based upon the perception of the administrator after participating in bargaining and after having worked with unionized faculty members, will thus determine that individual administrator's behavior and level of engagement while participating in these events.

After a thorough and exhaustive review of all of the study transcripts, field notes, and related literature five major descriptive thematic categories were discerned. These 
descriptive thematic categories were developed to organize the information that was received from the study participants relevant to the research questions into clusters of coherent patterns under descriptive headings (Bogdan \& Biklen, 2007; Fraenkel \& Wallen, 2003). These descriptive categories included: (a) the reason that the study participants entered higher education administration, (b) the administrative role in collective bargaining and working with unionized faculty members, (c) the negotiation preparation phase of bargaining, (d) the impact of bargaining and unionization across the higher education academy, and (e) the legitimacy of faculty unionization in higher education. These descriptive categories reflected the focus of this study, which was to gain an understanding of the administrative perspective of faculty unionization and the collective bargaining process, their perceptions of the administrative role, and the influence of bargaining and unionization on the relationships between faculty and administration.

Each of these descriptive categories and the supporting quotes from the study participants are discussed in this chapter, along with a brief description of each of the study participants. The use of supporting details in the form of quotes from the audio taped interviews and accompanying transcripts are included so that the reader can better understand the experiences and perceptions of the study participants first hand and gain insight as to how the researcher assigned the five descriptive categories used to explain the related study findings. The inclusion of these quotes from participants under each study finding will thus afford the reader the opportunity to trace and analyze the inductive reasoning behind each of the named findings, thereby enhancing the trustworthiness of the study (Creswell, 1998). For purposes of confidentiality, each participant was assigned 
a consistent pseudonym in the form of a first name. The names used do not directly reflect the identity of the study participants in any way. These pseudonyms will be used throughout the next few chapters when quoting or referring to a study participant.

Study Participants' Profiles

Study Participants: General Demographic Information

\begin{tabular}{lccc}
\hline Pseudonym & $\begin{array}{l}\text { Faculty } \\
\text { (years) }\end{array}$ & $\begin{array}{l}\text { Administrator } \\
\text { (years) }\end{array}$ & Degree \\
\hline Jackson & 13 & 14 & Ed.D. \\
Mary & 17 & 12 & Ph.D. \\
Carole & 0 & 20 & Bachelor's X2 \\
Tracey & 5 & 19 & Ed.D. \\
James & 14 & 17 & Ed.D. \\
Graham & 2 & 23 & Ed.D. \\
David & 7 & 29 & Ed.D. \\
Joni & 5 & 23 & Ed.D. \\
Lori & 6 & 21 & Ed.D. \\
\hline \hline
\end{tabular}

Study participants who were interviewed for this research project include five female and four male administrators from the higher education arena including two community colleges and two universities. The participants have been employed in the higher education arena for an average of 27.2 years. All but one of the administrators interviewed for this study had previously served in a faculty role. While serving in their faculty roles, three of the administrators interviewed were paying union members. The 
average age of the study participants was 50-59 years. All but one of the administrators interviewed had doctorate degrees. The overwhelming majority of study participants (7/8) hold Ed.D. degrees and one participant holds a Ph.D. in her specific discipline. At the time of their participation in bargaining as discussed in this study, one of the participants served as president, two as vice presidents, two as provosts, three as academic deans and one as department chair. The pseudonyms assigned to the nine study participants include Jackson, Mary, Carole, Tracey, James, Graham, David, Lori, and Joni. A brief description of each participant including demographic information, experiences and roles in higher education, some self-described attributes, and a few supporting quotes are discussed in this chapter.

Jackson

Jackson is currently serving as an academic dean at a college (formerly known as a community college) in southeast Florida. Before being employed in his current position, Jackson was employed at another community college in south Florida where he served as a faculty member for 13 years and then as department chair for 10 years. At the time of the interview and while participating in collective bargaining negotiations Jackson had been in his current role as academic dean for four years. Jackson is in the 50-59 year age range. In total, he has been employed in the higher education arena for a total of 27 years. Jackson entered the higher education administrative arena after acknowledging that he was burned out and ready for a change after working as a faculty member for 13 years. Jackson holds an Ed.D. in Higher Education. While employed in his faculty role, he never joined the union and was, therefore, never involved in negotiations and collective bargaining. 
Overall, Jackson described his first experiences working with unionized faculty members at his prior place of employment as uncomfortable, noting that the advent of faculty unionization at the first community college where he began his career in higher education was accompanied by a clear divisive distinction between faculty member and administrator. This distinction, he explained, was created at the top by the president and filtered down via the campus presidents and deans. Once the faculty unionized, his position as department chair position became an administrative position and included a new role, that of policing the faculty. He shared, "You were told that you had to check on the faculty. If they were supposed to be there at 8 o'clock, you had to document that they were there at 8 o'clock. It just got to the point where you were almost the police end of it." In addition to his new role as administrative police person, Jackson described a second new expectation, that of the hatchet person. He said, "And it got to the point that when there was a faculty member that they wanted out, it was up to you. You were basically their [administration's] hatchet person."

Jackson left his position as department chair at this first community college in the south Florida area to assume his current role as academic dean at another college where he has served for four years. Two years after coming to this community college, he was asked to sit on the administrative bargaining team by the chair of the administrative bargaining team, the Director of Human Resources. He stated that he was chosen because it was his turn. It was expected that all of the academic deans would take a turn at being a part of the administrative bargaining team. 
Mary

Mary, who described her age as being in the 60-69 year range, has served at her current university in south Florida as both a faculty member and as an administrator for a total of 29 years. She served as a tenured faculty member for her first 17 years at the college and was never an active, paying member of the faculty union. Mary has a Ph.D. in her social science discipline. At the time of her interview, Mary had been an administrator at a university in south Florida and served in a variety of administrative roles for the past 12 years. Her role at the time of the interview was that of provost and she continues to serve in that role. Mary has worked at the same south Florida university throughout her entire higher education career.

When asked what motivated her to get into higher education, she laughed and explained that it just happened. A friend told her about an adjunct position. She took it never thinking that she would stay in education so much so that she never got vested into the retirement system. Twenty-nine years later, she exclaimed, she is still there at the same university. When asked about her journey into administration, she said that it occurred in pretty much the same way. Her colleagues requested that she fill in various administrative roles and she did, never really expecting that she would stay on as an administrator for more than a term. She expressed, "I had no plan at all. I was asked to assume the role of department chair, I did. When the position of associate provost came open, my dean recommended me and again, it was, like, really!”

When asked how it was that she came to participate in negotiations, Mary explained that it was an assigned expectation as part of her job description. She went on to explain that she had witnessed and participated in bargaining before and after the 
devolution from state to local bargaining for the university system in south Florida. Before the devolution, Mary describes her participation in bargaining which involved flying to Tallahassee to bargain with the Board of Regents, "The administrative representatives from the 11 schools [universities] would sit on one side of the table while the union representatives sat on the other side of the table. The chief negotiator for administration was a Board of Regents staff person." Mary went on to explain that while decisions were made at the table regarding salary and benefits, it was understood that these items could be implemented only if the legislature supplied the necessary funding. There was not a great deal of tension between faculty and administrators because the final decisions were really out of the hands of the administrators from the local universities. Local bargaining began at her university in 2003 and she described the transition as a smooth one until about two years ago when state money for raises was cut and the college was not able to provide for faculty raises as it had in the past.

One of Mary's major concerns, as expressed several times throughout the interview, was the lack of interest and involvement of younger, tenure track faculty members in higher education administration. She pointed out that many of her administrative colleagues have doctorate degrees in higher education, but no experience as tenured faculty members. In addition, she vocalized that this concern is not unique to her, she said, "The president and I now talk about who is coming up behind us when we drive somewhere. I am going to be 60 something and he is going to be 60 something. As we look to the future, we need to bring someone in here who can understand." 
Carole

Carole, an Associate Vice President (AVP) for Academic Affairs at a university in south Florida, has been involved in higher education administration for 20 years. She has never been an instructional faculty member, although at her last job her particular position was classified as a faculty administrator. At the time of her interview, Carole had been in her current AVP position for four years. She has never been a member of a faculty union and describes her various administrative roles in higher education as being faculty support roles. She shared that "I always try to make faculty recognize that I am here to help them. That is my purpose here. I have no other purpose here."

When asked what it was that made her want to enter the administrative arena in higher education, Carole shared that it was not a purposeful decision. She was offered an administrative position supporting faculty in allied health upon graduating and continued to be assigned to different administrative roles. She expressed that after serving in an administrative capacity, she feels as though this is how she can best contribute to the university.

While discussing her involvement in collective bargaining and participating in negotiations, Carole laughed while saying that when she took the job, she was not aware that being involved with negotiations would be one of her assigned tasks and she was quite surprised when told that she would be on the administrative negotiation team. At the time of her interview as the result of some recent administrative changes and reassignments, she was assigned the role of chief negotiator for administration. While discussing this new assignment, Carole stated several times throughout the interview that she really felt that along with this assignment came a responsibility to continue to support 
the faculty in their role, she said, "So, I hope that the faculty sees me as more of a facilitator to help them get their job done than a burden."

Carole, like Mary, spoke about the devolution from bargaining at the state level in a collective group with the other 11 universities to bargaining at the local level. She stated that she is in agreement with many of her university administrative peers in believing that the devolution was a factor in bringing about a change in the relationship between the university faculty member and the university administrator. While discussing the devolution she stated:

What we have found, and almost every institution has commented that they feel that it has decreased morale. It has been more of an us versus them. Whereas before, and I don't like to push it off on someone else, but we could say, well that was decided up there [in Tallahassee] and we are trying to work with you.

Carole, who continues to serve in the provost's role at a university, was the youngest administrator interviewed for this study, citing her age as in the 40-49 year old age range. She currently holds two Bachelor's degrees and is working on her Master's degree. Tracey

Tracey, age range 50-59, holds an Ed.D. in Higher Education Administration. At the time of her interview, she had been employed in higher education for a total of 24 years. She worked as a faculty member for five years and has worked as a higher education administrator for the past 19 years. While in her faculty role, Tracey was never a union member. She has worked at three different community colleges, all referred to now as colleges in south Florida. Tracey continues to serve in an administrative capacity 
at a south Florida college and has been in her current administrative role for the past four years.

Tracey's interest in the union began upon assuming her first administrative role when believing that it was important for her to talk with and to understand the needs of the faculty, she would go to the cafeteria and sit with different faculty members at the "union table" after asking her supervisor if it was okay. Tracey valued the support of her immediate supervisor and several times throughout the interview spoke about what a profound, positive influence he had on her and her administrative philosophy and actions over the years. One of her statements about him was said with a lot of emotion: My experience with relationships, well clearly for 11 years, I grew up as an administrator under someone who valued people and values respect of the contract and worked for the betterment of the college. I was very fortunate. I tell him that to this day actually still. I know that he is very proud of me.

Tracey shared that while she loved teaching and felt that she was a good teacher, she went into administration to have more influence, to effect more change. She stated, "It was the sphere of influence that appealed to me to make me want to move up in administration. You can correct some of the wrongs that really bugged you as a faculty member."

When asked how it was that she ended up at the bargaining table as a member representing the administrative team, she stated she was asked after assuming her role as academic dean. The deans at her college all rotated in taking a turn. She believed not only was she asked because it was her turn, but the administration asked her to participate in negotiations after recognizing that she had a good relationship with the faculty and 
worked on one of the larger campuses, affording her the opportunity to have been faced with and to understand most of the issues causing contention that were brought to the bargaining table by the faculty.

James

James, who describes himself as a "pro-faculty administrator," is in the 50-59 age range and holds an Ed.D. in Higher Education Administration. He has worked in higher education at two community colleges in south Florida; both are now referred to as colleges. James has worked in higher education for a total of 31 years. He was a faculty member for 14 of those years. While a faculty member, James belonged to the union and was an active faculty participant and faculty representative in negotiations. At the time of his participation as an administrative bargaining agent, James was serving as an academic dean and then later as vice president for academic affairs at the same community college.

Having spent the past 17 years as a higher education administrator, when asked what it was that made him want to become an administrator, James said he was talked into assuming his administrative positions earlier in his career by his colleagues who wanted someone who could understand the needs of faculty and do a better job. $\mathrm{He}$ described this collegial encouragement as playing a major role in his administrative career saying that, "Every time I say I don't want to do this anymore, people would keep saying too many jerks will take your place. I did it out of guilt because I was afraid that there are too many stupid people out there that will do it." Encouraged by his faculty colleagues, James went into administration to avoid having someone incompetent or inexperienced with the faculty role assume the administrative position. 
James shared that his philosophy as an administrator was strongly influenced by many people in his life, who have displayed both positive and negative behaviors and ways of being. He went on to say that one of the positive influences in his life was as a kid, he remembers observing his father interacting with his employees. Reminiscing about his father's behaviors, he said, "If you treat your employees with respect, they will stand in front of a train for you. And I watched, and I learned, and that is what I did. I also remember watching my father when I worked there and going look at that, how did he stay so cool in that bad situation." James spoke for several minutes about his father's dedication to his employees as well as the employees' respect and commitment to his father.

James was first asked to serve on the administrative team in a consultant sort of role because he had the respect of the faculty. After serving in this role for one year, he was asked to serve for a second year by the president and he declined. He did not thing that serving again would be in his best interest. He shared the following:

I did it for one year and then I said no, I'd rather not because it does get [pauses and makes a frowning face]. And I want to maintain my good relationships. I don't want to waste chips if you will with the faculty over something like that [bargaining] because it takes too long to build up that good will.

James did serve on the administrative team a few years later under the direction of a different president when he was assigned to bargaining. That experience proved to be frustrating as he described working with a pro-faculty president and a board of trustees who did not share in the same appreciation for faculty. This difference in perspective led to much confusion and had a profound influence on his thoughts on bargaining and 
unionization for faculty members in the community college/colleges in south Florida. In terms of the bargaining process not being even-handed, he stated:

Unfortunately in Florida, with the collective bargaining agreement, if you go to impasse the board of trustees becomes the impartial arbitrator. They are not impartial. Do you think they are going to change their minds because an arbitrator recommends something? It is the most unfair practice in terms of bargaining. It is not a fair thing.

Graham

Graham has spent the last 25 years of his career in higher education, working in the community college setting in the south Florida region. He spent two years serving as a faculty member and 23 years serving in various administrative roles. When asked to describe his current age range he smiled and said, "Close to retirement, 50-59." He is currently serving as dean of academic affairs, a position that he has held for the past five years. While serving as a faculty member, Graham was not a member of the union at his college. Graham holds an Ed.D. degree in Higher Education Administration.

When talking about his evolution into higher education administration, Graham stated that he saw things that he wanted to see happen in his particular discipline, but as a faculty member did not feel as though he could prompt the needed changes. Regarding the need to be in an administrative role to effect change he stated:

In order to be able to do that you have to be in a position where you can effect change or at least attempt to by having the influence, if not the authority over people to do that. As a faculty member you have some impact over your classes, 
but you don't really have the arena available to act collectively to effect larger change.

Later in our interview when asked how it was that he ended up at the negotiating table as an administrator, Graham explained that his first time at the table was while he served in his prior role as department chair. He was asked by the president to be on the team. While his role was never specified, he went on to say that he assumes that he was asked to be a part of the team as a general consultant regarding academic affairs because of his close proximity to the faculty. He hoped that a part of the reason that he was assigned to bargaining was because the higher up administrators recognized that understanding the roles and needs of the faculty afforded him the ability to better understand the issues. After serving as an administrative representative on the administrative negotiation team for one academic year, Graham went on to be a member of the administrative team for a few more years. He stated that he did so because that it was a part of the service owed to the college as an administrator.

His most recent involvement in negotiations was while he was serving in his role of academic dean and while working with a new administrative team. He stated that his role continues to be that of consultant regarding academic affairs with the added responsibility of interpreting the contract and the purpose and language of those issues related to academic affairs in the current contract. Graham spoke several times throughout our interview about the need for and the value of a good, well written, enforced contract in promoting equity across the campus. He also addressed the need for administrator to have an understanding of the faculty roles and issues that they face in the 
classrooms. Regarding the need to understand the faculty role and issues and the value of a good contract, Graham stated:

Having been in the classroom and the faculty knowing that I was in the classroom helps because they [the faculty] understand that I know what I am talking about. By and large, I think that the collective bargaining agreement is a good thing when people follow it in good faith.

David

David stated this he is in the 50-59 year old age range and has been employed in various institutions of higher education in a few different states for the past 34 years. $\mathrm{He}$ holds an Ed.D. degree in Higher Education. At the time of his participation in the negotiations discussed for this study, he was the president of a south Florida community college. This was his second community college experience working with unionized faculty members and being a member of the administrative bargaining team.

David has served in an administrative capacity for the past 29 years. Before serving as an administrator, he was in a faculty role for seven years. While a faculty member, he was affiliated with the faculty union. David happened into his first administrative role before he was 30 years of age and progressed into the role of community college president before 45 years of age. While continuing to serve in an institution of higher education in an administrative capacity, he has now returned to the classroom a day or two a week, stating that he loves being engaged with the students and his return has helped keep him sane. Regarding administrative roles in higher education, he stated: 
I don't know many that have survived. I have to qualify this, I don't know of one survivor who has made a difference. You can't sell out. If you sell out and can live with yourself, more power to you. You get sick spiritually and physically. In addition, David shared that the more one becomes involved in administration the less he becomes a component of those he is representing, he said, "That's the other thing that I've learned about administration, the higher up you go and the more magnitude you have within the organization, the less you become an educator and a component of what you are representing."

When asked how it was that he came to sit on the administrative bargaining team, he said he was volunteered to serve on the team as it was an unwritten expectation of the president at that time to be at the bargaining table based on past practice. David stated several times throughout the interview that his experience with bargaining was less than ideal, a sentiment expressed by his oral statements and voice tone as well as his facial expressions. He clearly expressed that his dissatisfaction and chagrin were related to the bargaining tactics used by both the faculty and administrative team during negotiations including the withholding of information, arguing selfish personal interests, and a clear lack of trust and communication.

Joni

At the time of the interview, Joni was employed as a provost at a community college, a position that she was in for eight years. She stated that she was in the 60-69 year old age range. Joni holds an Ed.D. in Higher Education Administration.

Before becoming an administrator, Joni served as a community college faculty member for five years. While serving in her role as a faculty member, Joni did not belong 
to the union but stated that if she was a faculty member today, she would be much more inclined to join. She shared the following:

I think that when I first became a faculty member I was still living in my perfect world. I was thinking what happened to the professional to professional, to collegiality. I decided to stay out and to watch for a while. Then I became an administrator so fast that there was not really time to join. Incidentally, I had some friends who kind of felt the same way and in this current climate they have joined. I would be much more inclined to join now that I was in the past.

Joni, although personally opposed to faculty unionization, shared that she did see the need for such in today's political and economic context.

Joni has spent the last 23 years serving as a higher education administrator at the community college level in the south Florida region. She described herself as a strong faculty supporter and reiterated this several times throughout the interview. Regarding her feelings for the importance of the faculty member in promoting the mission of higher education, she said, "The faculty is what we do here. If it weren't for the faculty we wouldn't even have a college. I could go away, or the president could go away, and we would still have teaching and learning happening here."

When asked why she chose to become an administrator, Joni shared that she wanted to increase her sphere of influence:

I saw some things, like the classroom furniture wasn't right or we needed more technology, or whatever. I went into administration thinking maybe I could have an effect on more than just my students. Maybe I could help affect education in a broader arena. 
Joni explained that she was assigned to the administrative bargaining team to assist with the understanding and clarification of any academic issues and the possible ramifications of such that might be brought to the table by faculty members' issues. Overall, she added, that the experience was frustrating and artificial. She said that if she were to be asked to participate again she would easily say no.

Lori

Lori, a self-described 60-69 year old higher education administrator, has spent her last 27 years working in the higher education arena. She spent six of those years serving as a faculty member in a south Florida community college. Lori has been a higher education administrator for the past 21 years. For 15 of those years, she was in various administrative positions in the community college setting, serving a variety of roles including department chair and dean of academic affairs. She belonged to the union while in her faculty position and continued to pay union dues while serving as chair.

Lori holds an Ed.D in Higher Education Administration. She made a conscientious decision to enter higher education administration after trying to deal with a difficult situation with a colleague while serving as a faculty member. She voiced her frustration, relating that after she approached the administration with her concerns related to this situation and the potentially hazardous results nothing was done.

While serving in her department chair position, Lori was appointed to serve on the administrative bargaining team by her dean. Lori continued to serve on the administrative bargaining team for three consecutive years. She shared that it was this continued involvement that assisted her greatly during bargaining in understanding the negotiation process, the people at the table, the issues, and the contract. Several times throughout the 
interview, she stressed the overall lack of available negotiation training venues and shared how much she appreciated the opportunity to serve on the team for three years in a row, sharing that it really enhanced her knowledge and comfort level while seated at the negotiation table. In addition, she talked about the overall campus climate as being much more collegial in the past than it has been for the past few years sharing that this collegiality made bargaining more enjoyable. Lori attributed much of this collegiality to the tone set by the college president stating:

The old president at the time was there when I was involved in bargaining. It was a very nice place. Even after he left, the next president had a lot of control over the board of trustees and there was a very collegial relationship amongst the president, the board members and the faculty. People didn't get real militant about it [negotiations] because the president was able to keep it together.

Lori has since left the college setting and continues to serve in an administrative capacity at a university in south Florida. She shared that her leaving the college was not related to the change in presidents.

\section{Descriptive Categories}

After interviewing all of the participants and thoroughly reviewing all of the transcripts, field notes and literature related to faculty unionization and collective bargaining, labor laws in Florida, and higher education administrators, five major thematic descriptive categories were derived from the study interviews. Guided by the theory of symbolic interactionism, based on the study interviews and research questions, the five broad descriptive categories that emerged were: (a) the reason that the study participants entered higher education administration, (b) the administrative role in 
collective bargaining and working with unionized faculty members, (c) the negotiation preparation phase of bargaining, (d) the impact of bargaining and unionization across the higher education academy, and (e) the legitimacy of faculty unionization in higher education. These descriptive categories reflect the focus of this study which was to gain an understanding of the administrative perspective of faculty unionization and the collective bargaining process, their perceptions of the administrative role, and the influence of bargaining and unionization on the relationships between faculty and administration.

\section{Reasons for Entering Higher Education Administration}

The overwhelming majority $(\mathrm{n}=8)$ of the administrators interviewed for this study began their careers in higher education as faculty members at the same institutions in which they then later transitioned into their administrative roles. Five of the study participants spoke about their traditional progression along what is referred to as the normative ladder progressing from faculty members to administrators. They shared that they actively sought out an administrative role and clearly articulated their reasons for doing so. Three other participants did not actively seek out an administrative role in their institutions of higher education. Instead, they were thrust into their administrative roles, being assigned to their initial administrative role while serving as faculty members at their institutions. One participant ended up assuming an administrative position after a restructuring at her university. While the overwhelming majority (eight) of the study participants worked their way up through the ranks, beginning as faculty members at the same institution where they later transitioned into their administrative roles, none of them returned to their faculty positions. Five of the administrators have left the institutions 
where they were actively engaged with unionized faculty members and actively involved in negotiations as discussed in this study. Two of these administrators have assumed leadership roles at different colleges (formerly referred to as community colleges) in the south Florida region. Two of the participants have since assumed administrative roles at a south Florida university. All four of these administrators no longer work with unionized faculty members. One of the study participants has retired from her administrative position since being interviewed for this study. The study findings related to the journey that led each participant into the administrative arena in higher education for this descriptive category were broken down into two subcategories: the traditional/sought after route and the thrust into the administrative role route.

Traditional/Sought After Route

Six of the participants after serving as faculty members at their colleges followed the traditional path, climbing the academic normative ladder from faculty member to administration by choice. Their reasons for wanting to become a higher education administrator ranged in perspective from the global justification of wanting to make a difference in higher education, to a local justification of wanting to make a difference at one's institution, to a discipline specific goal of wanting to contribute ideas for change within a particular discipline, and to the very specific and personal desire of wanting to make a career change while staying in higher education after spending 13 years as a faculty member.

Seeking to have an impact on higher education at a global level, Tracey, a dean at a south Florida community college at the time of her participation in bargaining, shared that although she was happy in the classroom and enjoyed her faculty role, the appeal of 
having a broader sphere of influence led her to seek out an administrative position. While in the classroom, she saw some things that she thought could be changed for the better. Tracey saw higher education administration as the avenue needed in order to make a difference and to correct some of the things that bothered her when she was a faculty member working in the classroom.

Joni, who was serving as provost at the time of her participation in bargaining, also spoke of her desire to change things in higher education related to academics as the result of being in the classroom. Joni shared that she really loved to teach and felt that she did a great job in the classroom. She shared that while serving as a faculty member, she saw some things that needed to be added and enhanced to promote teaching and learning. She did not feel as though she could bring about the desired change as a faculty member. Instead, Joni felt that in order to have the needed impact on a broader level essential for bringing about the type of changes that she identified to enhance teaching and learning in the classroom, including such things as different furniture and enhanced technology, she would have to be a part of the administrative arena. Joni shared a sentiment similar to Tracey's. She chose to go into higher education administration to make a difference; to correct some of the things that bothered her while she was a faculty member in the classroom. Additionally, she chose administration to have a broader sphere of influence in academia.

Graham shared that his reason for entering administration was discipline specific. He felt that as a faculty member he lacked the authority to make the changes that he perceived as necessary for his discipline so that it would be seen in a more positive light. Graham related that in order for him to make the needed contribution to his discipline, 
often the subject of student disdain, he needed to have some authority over some of his discipline specific colleagues. He did not feel that he held the needed authority as a faculty member and, therefore, chose to enter higher education administration to gain that authority.

Jackson, an academic dean, had a personal reason for choosing to enter higher education administration. After spending 13 years as a faculty member at a community college in south Florida, he was "burned out." He stated that he reached a certain point in time where he recognized that he had two choices. The first choice, as he explained, was to continue on in the classroom despite being "burned out." He saw his second option as moving from the classroom to an administrative position at another south Florida community college. He chose the second. In discussing this choice, he said, "I was getting burned out from teaching. I wanted to try the administrative side. I felt as though I had to make a choice. I chose to become an administrator.” Jackson, having spent 13 years working in higher education, wanted to continue to work in the higher education arena. Burned out as a faculty member, he choose what he saw as the only option to do so, which was to join the administrative team.

Six of the study participants, Tracey, Joni, Graham, Jackson, Lori, and David, actively sought out an administrative role in their institutions of higher education. Three other study participants described that they were thrust into an administrative role. These three administrators were James, Mary, and Carole.

Thrust Into Administrative Role

Three of the administrators stated that they just happened into or were thrust into their roles as administrators, one from the community college setting and two from the 
university setting. These three administrators never made a conscious decision to enter the higher education administrative arena. Initially, two of the participants were placed into their administrative positions based upon the recommendation of their supervisors and/or colleagues, and one of the administrators was situated into her administrative role upon the recommendation of her supervisor following an organizational restructuring at her university. All three of these administrators were encouraged to stay in their administrative positions by the same supervisors or colleagues.

James entered his first role as an administrator on an interim basis at a community college at the prompting of his faculty colleagues. His faculty colleagues after witnessing the exiting of less than qualified administrators encouraged him to assume an administrative role in an effort to avoid getting someone else less qualified. In describing how it was that his faculty colleagues talked him into assuming various administrative roles, he shared:

They [faculty colleagues] said if you don't go into administration then we're going to have an idiot in that position. We need people like you in administration. I got talked into being department head for 3 years. Every time I say I don't want to do this [serve as an administrator] people [colleagues] keep saying too many jerks will take your place if you leave.

James, listening to the pleas from his faculty colleagues, was thrust into various administrative roles serving full-time temporary as department chair, then as dean, and finally as vice president of academic affairs. He never formally applied for any of these positions. 
James also talked about a realization that he had watched people come into his community college setting who lacked academic and leadership experience assume positions of leadership in his institution. He shared that he realized that if he did not join the administrative ranks, he would have to work for these inexperienced administrators:

I am not trying to pat myself on the back. I do it because I am afraid that there are too many stupid people out there that will do it if I don't. And then, I would have to work for that stupid person. I used to sit around thinking I could do a better job. So, James entered the administrative arena per the prompting of his faculty colleagues and in an effort to avoid having to work for an inexperienced outsider. James never formally applied for any of the administrative positions in which he served. After formal committees were formed and candidates interviewed, once someone was appointed to the administrative position in which he was serving as a full-time temporary administrator, he was asked to serve in another administrative capacity and he did.

Mary, a study participant from the university setting, was also thrust into various roles in higher education administration. She was asked to assume various administrative positions at her institution by her immediate supervisors. Mary stated that she entered higher education as an adjunct faculty member totally by chance upon the recommendation of one of her clients. She began her career in higher education while serving first as an adjunct faculty member. She soon became a tenured faculty member. After serving as a faculty member for 17 years, Mary was thrust into administration without ever having a clear plan or any set goals. Mary never sought out any of her positions in higher education. She never even sought out a position in the higher education arena. She began her entire academic career, including her administrative 
career by chance. Initially she took a job as an adjunct professor upon the recommendation of a friend. She continued to fill in as and where needed at the university upon the requests of her immediate supervisors. Sharing that she never joined the Florida retirement system is testament to her lack of seeking out a permanent position in her university.

Carole, another administrator and study participant from the university setting was also assigned to an administrative position. After some restructuring in her previous place of employment, her immediate supervisor placed her in an administrative position. Carole went on to say that once she experienced serving in an administrative capacity, she quickly realized this is where she preferred to be. Carole shared that although she never actively sought out an administrative role at her institution, she realized that as an administrator she could contribute to her institution:

Actually, I don't think that I purposefully did it. My department got transferred to the academic side of the university. I was put in charge of clinical faculty members. So, I never purposely did it but once I was in that role I was like this is where I can contribute the most. It was as close as I could come to making a difference.

Carole, like Mary and James, never actively applied for an administrative position in her institution. She was simply reassigned to an administrative position after some internal restructuring at her university.

In seeking to better understand faculty unionization and the collective bargaining process in higher education, the theory of symbolic interactionism encourages the recognition that one's practical life experiences, including the various roles in which one 
has served and one's interactions with others in seeking to make sense out of one's world, will thus influence one's perceptions of events. The events in the case of this study included working with unionized faculty members and participating in collective bargaining negotiations. The Theory of Symbolic Interactionism provides the framework for the recognition that it is necessary to understand that these experiences influence one's conscious decision making when deciding where to place his or her attention, as well as when deciding how to act and react in a particular situation within a particular context while recognizing the individual perceptions of all involved.

Several of the participants, regardless if they entered the administrative arena by personal choice or not, entered administration to make a difference after seeing some of what they perceived as the wrongs that needed to be made right while serving in a faculty role and being actively engaged in the classroom, or the desire to avoid having inexperienced outsiders assume administrative, decision making positions in their institutions. In response to a market driven economy, some caution that the higher education administrator of tomorrow may no longer have the background in academia and the understanding of higher education with all of its unique complexities (Plinske \& Packard, 2010; Risacher, 2004). Instead, many of these future academic leaders, based upon their experiences within a business or political contextual perspective, may choose to overlook the importance of shared governance, as well as the role and responsibilities of an effective administrator related to the general mission statement of higher education which is to promote teaching, learning, ethical research, and service to the community and to the nation while working with a community of distinct professionals dedicated to their disciplines and students. 


\section{Expectations of Administrators Related to Collective Bargaining and}

\section{Working with Unionized Faculty Members}

One of the predominate study findings that appeared to overshadow many of the responses during the study interviews is that the participants perceived and reported feelings of discomfort, disappointment, and/or frustration while participating in collective bargaining negotiation sessions. This finding is significant in terms of the total number of participants who expressed these feelings. All nine of the higher education administrators interviewed for this study expressed feeling some level of discomfort, disappointment, and/or frustration when discussing their participation and roles during negotiations. None of the administrators interviewed for this study actively sought out a position on the administrative bargaining team. All of the administrators interviewed shared that if given the choice, they would choose not to participate in negotiations again.

The forces attributed to the high levels of frustration shared by the study participants were identified as a lack of communication and support between administrative team members and higher up administrators and board members, and the administrative role strain related to being a member of the administrative bargaining team as well as a member of the academic community. The administrators interviewed for this study reported three areas of concern related to expectations of administrators related to collective bargaining negotiations and working with unionized faculty members including role assignment, role ambiguity, and role strain.

\section{Role Assignment}

Three of the participants were seated at the bargaining table representing administration because it was one of the assigned duties related to their job roles at the 
college or university. Six of the other participants were assigned to the administrative bargaining team by either the college/university presidents or by their direct supervisors. None of the administrators felt as though they would actively seek out active involvement in negotiations after having served on the administrative team at least once.

Study participants from the community college/college setting spoke of being assigned to serve while having to take a turn on the administrative negotiation team. Their assignments came from their direct supervisors, the head of human resources, or their college presidents. Only two of the study participants from the community college setting served on the administrative bargaining team for more than one consecutive term at the time that all of the participants were interviewed for this study. Once assigned to the team none of the administrators felt as though they could have declined.

Lori, one of the participating administrators in this study, was assigned to the administrative bargaining team for three years in a row. Although she said that she would not have voluntarily chosen to participate in negotiations a second or a third time, she did see her continued appointment as a positive thing for it increased her learning curve related to Florida labor laws, negotiations, and the collective bargaining agreement at her community college. In describing her continued appointments to the administrative bargaining team, Lori stated:

The first year, I was asked to go to bargaining sessions by W [immediate supervisor]. I went for 3 years. Three times, it was worth it. I think that you just have to do it the first time. The second and third time, I felt more prepared because I knew what to expect. I was more aware of the contract and law. 
In addition, Lori felt as though once she was asked to be on the negotiation team, it was her perception that there really was no choice. There was not an opportunity to decline, she said, "I didn't really feel like I had a choice. It was okay. In those days it was okay." Tracey, who served as an academic dean in the community college setting at the time of her participation in bargaining, shared a similar experience regarding being assigned to the administrative bargaining team. She added the additional caveat of rotating the responsibility to serve on the team, she stated, "You know they rotate that responsibility. My boss asked me to go and I went. He said you will represent administration." Tracey, like Lori, was assigned to represent administration at the bargaining table during negotiations. Neither of these community college administrators volunteered to serve on the committee. Once assigned, neither of the participants felt as though there was an opt-out option.

The participants from the university setting were assigned to the negotiation team by virtue of their job assignment. Along with the assignment came the unwritten expectation that they would continue to serve on the administrative bargaining team as long as they continued to serve in their roles as provost and assistant vice president for academic affairs. Carole, one of the study participants from the university setting, expressed that she was surprised when she was first assigned to serve on the administrative bargaining team. She went on to express that she hoped that this caveat was added to her description because her current boss recognized that she was concerned about doing the right thing and about the faculty, recognizing that in order for the university to be successful, the faculty needs to succeed. Carole stated: 
Well [R] didn't tell me that this would be one of my duties when he hired me! It was a surprise. I hope that one of the reasons he chose me for this and added it to my job description was because he knows my philosophy. I strive to do the right thing and I care very much about our faculty. I want them to be in an environment where they can succeed. If they succeed, the university succeeds.

Carole, upon assuming her assigned administrative role, was not made aware of the expectation that she would participate in bargaining sessions as a member of the administrative team. This information was shared with her by her immediate supervisor when it came time for negotiations. Additionally, her supervisor let her know verbally that it would be a continued expectation as part of her job description.

Mary, another administrator and study participant from the university setting also stated that she ended up on the bargaining team because her participation was an expectation as part of her job description, she said, "This was a part of my role as the provost. This was an assigned duty." Mary, like Carole, shared that being assigned to the administrative bargaining team was an unwritten expectation and that as long as she served in her current administrative assignment, continuous participation would be expected.

While the study participants from the university settings spoke of the inclusion of sitting on the administrative bargaining team in their job descriptions, they did clarify that it was not a written expectation, but one voiced by their supervisors. As part of this role expectation, the participants from the university setting recognized that this commitment would be a recurring one. The community college administrative participants also shared that serving as an administrative representative on the bargaining team was an unwritten 
job expectation. The community college administrative participants articulated tough that it was expected that every administrator would take a turn sitting on the administrative bargaining team, indicating that there was no expectation that an administrator would serve on the team for more than one consecutive bargaining term.

None of the administrators interviewed stated that they would volunteer to participate in negotiations again if they were given an option. Their reasons for preferring not to serve on the administrative bargaining team included being perceived as the bad guy by faculty, being in an academic administrative role with the expectation that one would support faculty in their academic endeavors, not wanting to alienate the faculty, not wanting to have to pick a side, and the lack of support from the president and/or the board members. James, who was serving as an academic dean and then later as an academic vice president at a community college during his period of active participation with negotiations and bargaining, spoke about his discomfort when confronted by a board member after she saw a picture of him at a union event following negotiations. She passed the picture around to other administrators and board members and asked him whose side he was on in front of the group. James shared the following:

I went to a union party as many administrators do. Somebody took my picture.

She [the board member] made copies of the picture and passed it around while at the same time asking me whose side I was on. I said, without blinking an eye, I am on the side of the college and the students. I am not on the administration's side or the faculty side. 
James also talked about his discomfort with bargaining as an administrative representative while serving in a role that he perceived to be an academic support role. He spoke about the dissonance that he experienced:

As an academic administrator, you need to maintain that relationship with the faculty. You need them to help you with learning outcomes and all of those other innovative things. If they look at you as an adversary, that is a bad thing. I've got to be their advocate. I can't be the one screwing them. I wouldn't do it again. As a member of the administrative bargaining team, James experienced feelings of disconcert. He was embarrassed and puzzled by the comment of the member of the board of trustees after attending a union party. In addition, he recognized that as a member of the administrative bargaining team, he might be viewed as the foe of the faculty, which might then cost him faculty support while working on academic projects.

Jackson, also an administrator from the community college setting, voiced his concern over being perceived as the bad guy after participating in negotiations as an administrator. His concerns were related to the perception of faculty members after seeing the new contract. He stated, "It is really not fair for your colleagues to have to invest all that time in negotiations because then they end up the bad guy when the contract comes out."

Jackson, like James, was concerned that after participating in negotiations as a member of the administrative bargaining team they would then be perceived by faculty members as being the bad guys. Both Jackson and James served as academic deans at one time throughout their bargaining assignments. 
Tracey, serving as an academic dean at a community college while working with unionized faculty members and participating in collective bargaining sessions, spoke of her discomfort and lack of willingness to volunteer to sit on the administrative bargaining team after serving for one bargaining term. Because of what she perceived to be the unfortunate resulting decisive split between faculty and administration as a result of negotiations, it was just too uncomfortable for her. Tracey described her discomfort and resulting attitude toward serving again in the future in the following statement:

The bargaining sessions were uncomfortable. It is built-in adversarial. I found myself thinking, I don't like that, I don't want to be here, but I care about the college. The college is good. Faculty is great. I like my boss, and there is a lot of potential. So, I told myself to speak up when something was really bothering me and to just shut up for the rest of it. Not again.

Tracey spoke of her discomfort with negotiations as being related to her perception of bargaining as being antagonistic in nature. She attributed the decisive split that she witnessed between faculty and administration at her community college as being in part related to this adversarial bargaining process. For Tracey this adversity was the antithesis to a preferred collegial way of interacting with faculty members. After serving on the administrative bargaining team one time, she said that she would not serve again if ever asked.

Graham, also a dean from the community college setting, stressed that though he would not chose to be seated at the negotiation table again; he did feel as though his feedback as academic dean was needed. He felt as though many of the administrators who were seated at the table were too far removed from the classroom and the faculty to 
understand the issues and the impact of the contract. He went on to clarify that although he would not actively seek out inclusion on the administrative bargaining team as a visible entity seated at the bargaining table, he would seek out inclusion as a behind the scene consultant. Graham shared the following:

I think that it was recognized by some folks who were seated at the table that they were not close enough to the academic issues. As far as participating in bargaining again, I probably would not. It's just not my thing. I do think that it's important for the administrative bargaining team to get feedback from people like the academic deans though. Now having said that, I don't think that we have to sit at the table. But clearly the issues that come up are of an academic nature. I wouldn't mind serving as a consultant; telling them what I understand and giving them feedback from the other deans or my associate deans. I don't really want to sit at the table though.

Graham recognized that administrators from the academic side of the college needed to be included in bargaining. He felt as though many of the administrators seated at the table were too far removed from the academic issues being discussed during collective bargaining negotiation sessions. He did not think, however, that it was in the best interest of the deans or the faculty members for the academic deans to actually visibly be seated at the bargaining table representing administration. He said, "It is the job of the academic dean to represent faculty in all matters related to academics."

Role Ambiguity

There is a great deal of information available in the social science data base related to role confusion and the effects of such in the workplace (Anderson, Murray, \& 
Olivarez, 2002; Bowker, 1982; Bray, 2008; Weppner, Wilhite, \& D’Onofrio, 2002; Wild, Ebbers \& Shelley, 2003; Wolverton, Wolverton, \& Gmelch, 1999). The participants that voiced the most frustration with collective bargaining and the negotiation sessions in the case of this study were serving as academic deans while participating in bargaining and negotiations as administrative representatives. These academic deans expressed concern related to the lack of a clear definition as to what their role would be at the bargaining table and the expected associated behaviors.

The majority $(\mathrm{n}=5)$ of the study participants interviewed for this study from the community college setting expressed that their role at the negotiation table was never made clear. This uncertainty involved what it was exactly that they were supposed to do or say during negotiations, and resulted in the participants feeling frustrated over not being needed or utilized while seated at the bargaining table. Related factors leading to dissatisfaction and role ambiguity for these administrators included not being able to engage in conversation with the faculty members at the table, the lack of communication between administrators related to role assignment, and the lack of any voiced role expectations.

Joni, a community college administrator who was serving as an academic dean at the time of her participation in bargaining, shared her feelings related to the role ambiguity that she experienced as a result of never really being clear as to what she was supposed to do as a member of the administrative bargaining team during negotiations. She expressed that she felt useless and frustrated during negotiations. Joni stated: 
I think that my role was to be a window dressing. It was frustrating. I wasn't sure what I was doing sitting there at the table. I felt very much in the dark. If you really want me here and you really want my input, then get my input.

Joni shared that not only was she frustrated while seated at the bargaining table but she was also often left feeling disgruntled following negotiations due to not being recognized in that she was not asked for any input.

Jackson, another community college participant expressed a similar sentiment. Not only was his role never explained, but his expected level of participation was not made clear even when it was not expected any more. This lack of communication regarding his role as a member of the administrative bargaining team left him feeling dissatisfied and frustrated:

We were never really clear as to whether or not we would even be included in sessions. It got to the point where there was no communication from the administrative chief negotiator. We ended up basically excluded from the sessions. This was never communicated even.

Jackson experienced what some of the other study participants described as role ambiguity in that it was never really made clear to him what the role expectation was for him as a member of the administrative negotiating team, who was expected to be seated at the negotiation table. Toward the end of negotiations when things became contentious at this institution, he was not even expected to be at the table. This was not told to him directly though. He just sensed that he was no longer supposed to be seated at the table. Although the lack of a clear role assignment during negotiations was not brought up by the administrators from the university setting, Mary, one of the participating 
administrators interviewed for this study, did express a similar sentiment when she participated in bargaining at the state level earlier in her administrative career. She too was not given a clear description of her role and the assigned expectations the first time she went to negotiations, Mary said:

It was a big shock to me. We said nothing really. In fact I came to the table not even knowing where to sit. The chief negotiator came to me and said I was sitting in her seat! We all sat around and nobody said anything. That was when we bargained at the state level.

Once bargaining was moved to the local level, Mary's role was made clear by the chief negotiator for her institution. She was assigned to be a consultant to the lead negotiator for the administrative side. Although this role was made clear, the inherent duties were occasionally blurry. At times, she would find herself with something to say about an item being discussed and not really sure if it was appropriate for her to address it while at the negotiation table with faculty, or to hold off and discuss it in a caucus with just the administrative team. She was always aware that a lot of what was happening at the table was strategy:

I know who is in charge and who takes the lead. I still feel like I have to think. As I am sitting there I think, do I say anything? I am not sure whether to bring this up now or later in caucus. Everything with him [chief negotiator] is strategy. While Mary's assigned role as an administrative representative at the bargaining table was made clear she like the majority of the other study participants was not always sure of the expectations assigned to that role. 
Role ambiguity in terms of never being sure of what was expected of them as members of the administrative bargaining team was expressed by the study participants, in particular those administrators serving as academic deans at the time of their participation in collective bargaining negotiation sessions. Mary expressed that though her role was made clear by the lead negotiator at her institution she did experience some confusion throughout bargaining related to the duties inherent to her assigned administrative bargaining team representative role.

Role Strain

Role strain, as defined by social science theorists, is experienced when one has trouble fulfilling expected tasks due to a lack of consensual commitment or an easy integration between the expected task and one's philosophical beliefs related to how they should be or act in a given situation with a given population (Goode, 1960). Role strain can thus result when one is given an assignment and directed to carry that assignment out without the needed resources, including organizational commitment and support, and when that assignment is not congruent with one's beliefs about who they are and how they interact with others. In the case of this study, the higher education administrators from the community college settings voiced their feelings of chagrin related to both having to do one thing as the result of an administrative directive while not thinking that it was the right thing to do from an academic standard and the lack of perceived organizational support in terms of resources and administrative feedback and support.

David, a community college administrator at the time of his participation in bargaining, addressed the lack of the support of the board of trustees in terms of sharing the needed resources, which in his case was information. Additionally, when it came 
down to the final hour in negotiations, the board withdrew their initial proposal, demonstrating a lack of support for him and the other members of the administrative bargaining team. He stated:

Administration in its typical approach to things generally does not share all of the facts. Be it ego, be it bureaucracy or be it whatever. There was always some doubt as to whether or not we were being told the truth. I experienced reaching agreement with the union during negotiations and then when it came to the $11^{\text {th }}$ hour and it was time to ratify the contract in a closed session, one of the board members said, I'm not doing that after all. I've changed my mind. She threw me under the bus with no warning.

David shared that this overall lack of support and allegiance from members of the boards of trustees is not an unusual circumstance in higher education. He spoke about the low number of colleagues he know who remained in administrative positions for any length of time, particularly college presidents. He talked about the detrimental impact of not having a supportive organization in terms of the board of trustees and how this affected him. This lack of support led to varying degrees of role strain. He voiced these sentiments as follows:

What do you do if you have devoted your entire life to wanting to make a difference in higher education and then during negotiations someone [board member] crucifies you? The last person that I knew who had been continuously in a leadership role as a president just got fired last holiday. She was crying. I just said, oh God, I don't know many that have survived. 
David spoke about the role strain that he experienced as an administrator resulting from conflict between administrator and administration, which in his case was between him, the president, and the two of members of the board of trustees. The role strain that he experienced resulted from a lack of support in terms of the board members providing the needed information during bargaining sessions and in terms of the board members withdrawing their support, often resulting in employment termination.

David also spoke of role strain related to having to act contrary to one's beliefs and the stress that this incongruence placed on him and colleagues of his:

I have to qualify this, I don't know of one survivor who has made a difference. You can't sell out. If you do and you can live with yourself more power to you. You get sick spiritually and physically. Psychologically you are a basket case. David, a college president at the time of his participation in bargaining as discussed in this study, described three sources of role strain. He discussed the lack of needed resources from the board of trustees, the lack of perceived support from the board of trustees, and the need to act in a way not congruent with one's personal beliefs as the result of a directive of administration, which in his case was the board of trustees.

James, a community college administrator, also spoke about the importance of having organizational support in terms of having the support of the person above you. This support was a key factor in allowing him to be who he was and to be able to act in congruence with his personal philosophy. He shared the need for supervisory support and the consequences that can come about without such as follows:

I have worked with the good and the bad. The problem is even if you might be that way, supportive and encouraging allowing for innovation, if you don't have 
the support of the person above, you're screwed. That is the one reason that I don't think you should stay in that [administrative] position. You'll wake up in the middle of the night. You'll have angst and you'll have heartache because you're not getting that support. It is one thing though to have support from the provost. You need more. You need to have it from the board of trustees.

James shared in the beliefs that were expressed by David. In order to be a successful administrator and negotiator, the support of the board of trustees is needed at the community college level. Both of these community college administrators spoke about the personal toll that the lack of this support from the college administration for other administrators takes in terms of one's overall physical and psychological well-being.

A third community college administrator, Tracey, spoke of the organizational support that she did receive from her immediate supervisor. She shared that the backing and encouragement that she received from her immediate supervisor has had a positive, long reaching effect on her. She also voiced her gratitude when stating how the continued support of her immediate supervisor has helped her to be the administrator that she is today. Tracey shared that her supervisor always encouraged her to act based upon her personal belief which is that all human beings should be treated with respect. Tracey shared this in the following statements:

I grew up under someone who valued people and values respect of the faculty contract. Someone who worked for the betterment of the college. I was very fortunate. My relationships with faculty members over the years have been good. People are people, they like you to tell them what is going on, to support them. I am who I am today because I had the support of a great boss. I was very fortunate. 
Tracey experienced the opposite of both David and James. She perceived that she had the support and encouragement of her immediate supervisor and because of this she was able to do her job as she thought it should be done. In addition, Tracey felt as though her immediate supervisor shared in her inherent beliefs related to the worth of the individual faculty member and the value of the faculty contract as was demonstrated by not only his encouragement, but also by his actions.

All of the administrators interviewed for this study were academic administrators at the time of their participation in bargaining. Academic administrators hold a unique position in academia. While considered administrators in their institutional settings, they differ from many of the other college and university administrators in that their primary responsibilities involve teaching, learning and working closely with faculty. These responsibilities command the cooperation and trust of the faculty members across the campus, while at the same time they themselves must cooperate and trust the other members of the administrative team. These two constituents often hold conflicting views and priorities causing the academic dean to experience role conflict and role ambiguity (Bowker, 1981; Bray, 2008; Wolverton, Wolverton, \& Gmelch, 1999).

Mech (1997) described role conflict as a source of job dissatisfaction for chief academic officers. He cited the dichotomy between what is expected of the chief academic officer as the formal authority figure and what can actually be done in the collegial, decentralized work environment as one of the major attributing factors of this role conflict. He stressed that while by virtue of their job description these academic officers have the formal authority to make decisions, they lack any real power to 
implement any of these decisions. The ultimate decision making power really resides with the president and the board.

While the administrators interviewed for this study addressed role conflict and the impact of such on job satisfaction, symbolic interactionism affords a similar view for the administrator who experienced the same role conflict and role strain. From a symbolic interactionism theoretical lens the experiences, interactions, and resulting views one holds after participating in an event and forming one's own perspective will thus impact that individual's behavior and active choice making in the future. As expressed by the administrators interviewed for this study, who were active participants in union negotiations while with unionized faculty members, one result of their experience with the negotiation process and working with an administration that was often perceived as not being supportive of these administrators, is that they would not actively choose to participate in bargaining negotiations again if given the choice or opportunity.

One of the predominate study findings that appeared to overshadow many of the responses during the study interviews is that the participants perceived and reported feelings of discomfort, disappointment, and/or frustration while participating in collective bargaining negotiation sessions. All nine of the higher education administrators interviewed for this study expressed feeling some level of discomfort, disappointment, and/or frustration when discussing their participation and roles during negotiations. None of the administrators interviewed for this study actively sought out a position on the administrative bargaining team. All of the administrators interviewed shared that if given the choice, they would choose not to participate in negotiations again. 
The forces that attributed to the high levels of frustration shared by the study participants were identified as a lack of communication and support between administrative team members, higher up administrators and board members, administrative role ambiguity, and administrative role strain. Role ambiguity was related to the overall lack of communication to the members of the administrative bargaining team as to their assigned roles and expected behaviors while seated at the bargaining table representing administration during negotiations. Role strain was experienced by some of the study participants in that they reported a lack of perceived support and resources from administration at their colleges while participating in bargaining and being assigned to tasks and duties that were in opposition to their philosophical beliefs.

The Negotiation Preparation Phase of Bargaining

The overwhelming majority (eight of nine) of the administrators interviewed expressed that they were not prepared to participate in union negotiation sessions. While eight of the administrators interviewed did not undergo formal negotiation training, they did express that it would have been helpful. Graham saw the need for training related to the specific role and expectations for the administrator at the bargaining table, but was clear in stating that it had to be the right kind of training. He stated that training would have been especially helpful in providing the necessary tool to aid one in dealing with bargaining and negotiation when things took a turn for the worst. Graham, an academic dean, shared the following:

Training, none [laughing]. That is an important point. I do think that some training needs to be there, just in general. Especially as I got into bargaining in the later stages, when things weren't going well and there was more formality 
involved. Now that I've been through it, I think back and think we probably shouldn't have done that or looked for this, and that was the wrong approach. It [lack of training] leads to problems and maybe unnecessarily so. I do think that the right kind of training would have been helpful. I don't mean somebody academic from some institution that comes and gives us broad outlines.

Graham, after reflecting on the negotiation sessions that he had participated in right before being interviewed for this study, articulated that training related to the negotiation process and dealing with contentious bargaining sessions would have been helpful in terms of what to look for and what to do and what not to do in an effort to be aware and perhaps prevent some of the things that happen when tensions are running high. $\mathrm{He}$ elaborated on the training that he would have liked to have had sharing that it must be the right kind of training. He said that too often in academia, we bring in people from other institutions for training sessions who lack the practical experience and that is just a waste of time in his opinion.

Carole, an administrator from the university setting, shared that before participating she did go out to look for printed resources about negotiation training. She said that she was not able to find any information of real value. She found that instead of continuing to search for resources, it was easier to sit back and listen and learn from the chief negotiator. In addition, she sought assistance from administrative colleagues who formally meet once a year to discuss current trends and issues, including bargaining and what other institutions of higher education are doing. Carole shared the following:

Training was more of a learn as you go. When I first started, I kind of just sat back and watched. I did go out and try to look for resources. There were a few 
books about position bargaining and I did try some ideas. You kind of learn from the situation as to what works and what doesn't. But we also have support groups from the administration perspective, just like the union would, in terms of my peers at the state and national level. We meet once a year.

Discouraged after looking for available resources to help her to prepare for collective bargaining negotiations as a member of the administrative team and not able to find anything that she thought might be helpful, Carole turned to an observatory role in negotiations. She also sought the assistance of a support group composed of other higher education administrators.

Joni, a community college administrator, discussed the need for both administration and faculty to participate in negotiation training and workshops together. She added that there needs to be additional training offered to administrators with a focus on understanding faculty in terms of their commitment to the students, the institution, and to their professional disciplines and the role that they play in institutional success. Related to the need for pre-negotiation training for administrators Joni said:

I honestly believe that both bargaining teams should have not only training but maybe a workshop together. I'd also like for the administrative bargaining team to realize that the faculty is where it is at. If it weren't for the faculty we would not have a college. I think we've lost that and need it back.

Joni felt as though the administrators, who were involved in collective bargaining and worked with unionized faculty members, needed training regarding both of these roles. She saw a need for collaborative training sessions between faculty and administration stating that this might result in a more collaborative effort to resolve issues once at the 
bargaining table. In addition, Joni disclosed that she believes that administrators who did not previously serve in a faculty role should undergo additional training to understand more about the academic side of the college, in particular the role that faculty members play in institutional success.

Lori, another community college administrator, also voiced her frustration related the lack of any pre-bargaining training for administrators assigned to the bargaining team. She stated:

I think that you need to know what the issues are for administration and what the issues are for faculty. I think you need to know your team and what they expect of you. Are you just the token person on the team [laughing]? I think that just saying to the team up front, what is the agenda for me. What happened before is important. Again, it only takes one member to blurt out something stupid. Lori, like other administrators interviewed for this study, recognized a need for administrative training related to bargaining. She felt that training in regards to the role and related expected behaviors of the administrators on the bargaining team, the issues being brought to the table by the faculty members, the institutional history and relevance of such, and contemporary bargaining issues from other institutions in the surrounding areas was essential.

Only one of the study participants, who happened to be from the university setting, shared that she had received any type of training in negotiations. Mary shared that with the advent of local bargaining at her university, following the devolution, the administrative team opted to bring in an outsider to serve as chief negotiator. His role as chief negotiator included educating the administrative bargaining team about state labor 
and bargaining laws, as well as about negotiations and bargaining. Addressing the use of an outside chief negotiator, Mary stated:

We decided to hire [B] from the outside. He is familiar with what is happening in most all of the institutions of higher education in the state. He has participated in collective bargaining at the state level. He was very helpful to me in understanding that both sides have to walk away feeling that they have won something. He also helped me to understand $\mathrm{CH} 447$ [state statute]. He helped a lot with the specifics.

Mary shared that the real value of the training that was offered to her was that it assisted her in understanding the negotiation process and state regulations related to employment, labor laws, and bargaining in Florida.

In one study looking at leadership training (Hull \& Keim, 2007), leadership training initiatives focused on team building, institutional purpose, values, culture, mission, budgeting, funding, and governance over $60 \%$ of the time. Areas that were focused on under $50 \%$ of the time included crisis management, leadership assessment and theories, conflict resolution, and the role of the board of trustees.

Formal educational programs, cited by some as essential to the making of a good leader, included advanced doctoral degree programs leading to a discipline specific Ph.D. or from Ed.D. programs with a focus on higher education and leadership. This formal university training has gained momentum over the past few decades. Over the past 50 years, the number of higher education administrators holding doctorate degrees has risen over $30 \%$ and is now estimated to be at about $80 \%$ (Hull \& Keim, 2007). While these formal programs are often strong in history, theoretical foundation and research 
strategies, some complain that they are weak in offering real-life practical advice stating that much of the information offered in these programs is outdated and impractical, especially in areas related to conflict resolution and communication (Brown et al., 2002; Hull \& Keim, 2007). This overall lack of training related to the real-life negotiation process was reported by the majority of the administrators interviewed for this study. Interpersonal Relationships Between Faculty and Administrators

The majority of the community college and university administrators interviewed for this study indicated that they have personally experienced or witnessed a definite "us versus them" mentality between faculty and administration on their campuses. They proposed several possible attributing factors as contributing to this decisive split including the need to strictly adhere to a contract, the nature of bargaining in that it is set up to be a contentious process, the behavior of some of the faculty members seated at the table acting as faculty union representatives for the faculty at large, and the actual negotiation process at their institutions.

Jackson, an academic dean in the community college setting, spoke about the negative impact of unionization on the faculty and administrator relationship at the institution where he was first introduced to faculty unionization. He believed that in part, one of the circumstances related to this negativity was the bureaucratic restructuring of the college that was needed to support negotiations, faculty contract issues, and the enforcement of such. Having to abide by the contract and police the faculty to be sure that they were doing the same was a new, unwritten job role expectation on his part once the faculty became unionized. He also talked about how unionization was directly related 
to the lack of collegiality between administrators and faculty. Jackson shared the following:

I think that unionization and collective bargaining has had for the most part on a negative impact on the faculty-administrator relationship. You always have that thing [the contract] hanging over your head. You don't have that friendly, cordial relationship. I think that with administration it is a we versus them relationship. It is not a collegial thing whatsoever. You could not just sit down and say this is what the problem is and here is how we can work it out. You have to be very structured when you have that union representative there because there could be a grievance filed against you. You [administrators] were told by the campus president that you had to stay to the contract, by the letter of the law. You were told that you had to check on the faculty. If they left early, you had to document that. It was just that everything had to be documented. It just got to the point to where you were almost the police. It almost got to the point where it was a hostile work environment.

In addition to faculty unionization bringing about an "us vs. them" mentality at his institution, Jackson perceived that faculty unionization resulted in the need for a more formal system of checks and balances between faculty and administration with both sides having to strictly adhere to the faculty contract. He shared that not only were the administrators at his institution afraid of a grievance being filed against them if they deviated from the contract, but the faculty were acutely aware that they were being closely scrutinized to be sure that they were following the contract. 
Study participants also spoke about the sometimes antagonistic relationships between faculty and administration while at the bargaining table and after negotiations were completed. They perceived that these antagonistic relationships negatively influenced communication between faculty and administration. These participants related that it was not all faculty members, it was not even the majority of the faculty members who behaved in opposition to administration, and it was only a few of the faculty union representatives who were seated at the negotiation table. A few of the administrators spoke about how after some of the bargaining sessions, some of the faculty members who were at the table and some who were not but heard about what was said and done during negotiations, came to them afterwards in confidence and apologized.

David, a study participant who worked in the community college setting spoke about the bitterness expressed by one faculty member who was a faculty union representative seated at the bargaining table. While discussing his assessment of her and what he perceived to be the negative consequence of her behavior, he said:

It was about her. She controlled the union. When collaboration ended with her, I saw the division that it caused. Both sides dug in. Many of the faculty, because we are all human beings, just got sucked in. You know most of them don't have the sword and the shotgun in the car!

David was clear though in that it was only the president of the union that acted in this way. He felt that the faculty, at large, were reasonable in their expectations and not confrontational by nature. 
Mary also spoke about the antagonism expressed during negotiations by some of the members of the faculty bargaining team. She too clarified that these actions were displayed by only a core few. She stated:

Every once in a while, well, like right now we have a union member who spends her days posting negative blogs about me, the trustees, and the president. We had a guy who posted a nasty caricature of the president in a newsletter right after both sides had agreed to everything. He [the president] was pissed. But he never asked for faculty consultation before posting it. It is interesting to me that we can be at the bargaining table and everything is very contentious and then we go to a reception at faculty senate and everyone is very cordial. I guess that bargaining is contentious for everyone but it does not have to carry over into all of our activities.

Mary, disappointed in the negative behaviors of a few of the faculty union representatives, shared that she was impressed by the ability of faculty members as a whole to separate bargaining and what she perceived to be as some of the associated negative issues that were often involved. She was surprised when after several difficult bargaining sessions; faculty members as a whole were still engaged in the everyday activities of teaching, learning, and campus life.

Another administrator from the university setting, Carole also discussed the closed mindedness of some of the faculty union representatives seated at the bargaining table. After observing some of the behaviors and negotiation tactics used by some of the faculty representatives, Carole lost respect for those faculty representatives. She shared that other faculty members and administrators on her campus expressed that they 
sometimes felt that the larger body of faculty members did not really know how close minded their representatives were and how that close-mindedness affected their behavior at the bargaining table. She said:

I have heard from other faculty members after they came to a bargaining session that they didn't realize some of the perceptions or close-mindedness of some of the faculty representatives. Several people [faculty and administrators] have commented to me that they thought that if the other union members were aware of these things, there might be a change in union leadership.

Carole was also clear that it was only a few of the faculty union representatives who were seated at the table that she had trouble with, not the faculty body as a whole. She also spoke about being visited by faculty members who were not acting as union representatives, but who went to negotiation sessions as observers. They too were disappointed in the behavior of some of their union representatives.

Joni, a provost in the community college setting, felt that unionization and bargaining had influenced the working relationships between faculty and administration on her campus resulting in a us versus them mentality. She said, "The biggest minus of faculty unionization and collective bargaining is the "us and them" thing that just sort of naturally comes out of that. I think that it's so nonproductive to have that mindset."

Joni went on to discuss the need for collegial discourse on a college campus to broaden the educational experience of the student. While she did not discuss a direct correlation between unionization and the lack of collegial discourse, she did express that she believes that the definitive split and the resulting lack of respect that came about 
between faculty and administration was in part related to unionization and bargaining. Joni shared the following:

I'll go back to what it is that we do, our mission. It goes back to why faculty unionized in the first place. This is a college. This is where people are supposed to be able to speak out. This is supposed to be the think tank where we look at different points of view. This has to be done collegially and is only possible when there is respect on both sides. I think that is something we have to model for our students, how we resolve dissension. If we're yelling at each other, what does that tell them?

Two of the study participants stated that they felt that some of the issues related to faculty unionization and bargaining have negatively impacted the domain of the faculty senate on their campuses. They shared that on their campuses faculty negotiation team members, who harbored some animosity related to administration and bargaining, were also faculty senate leaders who then brought some of their anger and frustration to the senate. Related to this segregation between faculty and administration and the carrying over of some of the animosity generated in negotiations to the faculty senate, Carole related the following:

Overall, unionization and collective bargaining in higher education has resulted in stratification between administrators and faculty. What we have found is that, and almost every institution has commented, that they feel collective bargaining has decreased morale. It has made us more of an us versus them. I think too that from a faculty governance perspective with the union, it is all so intertwined now. You see the same union leaders being the faculty senators and it bleeds there. 
Carole shared that at the university where she is serving in an administrative capacity many of the union leaders have attributed to a working environment that is less than ideal. There is a decisive split between faculty and administration and low morale all the way around.

The initial response of the Carnegie Commission contemplating governance in institutions of higher education over 35 years ago included six recommendations, one of which was directly related to the separation of union and senate. The recommendation called for the use of discretion when looking at those issues that should be dealt with in a union contract, limiting such to economic issues and benefits versus those issues that should be left to faculty senate including matters primarily related to academic affairs (Garbarino \& Aussieker, 1975).

Negotiation has been defined in various ways by academicians. For the most part, definitions include a reference to the involvement of two parties, who hold opposing views and often have opposing interests who need to reach some sort of agreement through bargaining (Birnbaum, 1980; Lewin, 2005; Zagelmeyer, 2005). While study participants voiced a belief that both parties (administrators and faculty) have opposing views and interests, an extensive literature search did not confirm that faculty members tend to perceive those administrators who are present at bargaining table as the enemy or "bad guys."

Addressing the preferred difference in the communication styles by faculty and administrators, Jette (2005) examined negotiation tactics of teachers and administrators. He noted that administration favored the use of dialogue at the bargaining table while the educators preferred debate. This recognition of the differences in the preferred type of 
negotiation communication is an important one. It will be the perception of the individuals and the administrators involved in negotiations and the everyday interactions with unionized faculty members that will thus influence their interpretation of faculty unionization and bargaining.

In the case of this study the administrators seated at the bargaining table reported that they have personally experienced or witnessed a definite "us versus them" mentality between faculty and administration on their campuses. They proposed several contributing factors that aided in this decisive split on their campuses including the need to strictly adhere to a contract, the nature of bargaining in that it is set up to be a contentious process, the behavior of some of the faculty members seated at the table acting as faculty union representatives for the faculty at large, and the actual negotiation process at their institution. Not all of the administrators interviewed for this study felt as though unionization and bargaining has affected the relationship between faculty and administrators on their campuses. Some reported that the tone for the faculty administrator relationships across campus is set by the college or university president. The Role of the College President

Two of the administrators from the community college setting, who participated in this study, did not believe that the relationship between faculty and administration was influenced by the presence or the absence of unionization and bargaining. In conveying her belief that it is actually the president who sets the tone contributing to the relationship dynamic across the campuses, Tracey stated:

I don't think that faculty unionization or participation in collective bargaining impacts the faculty-administrator relationship. You know, again, it starts from the 
top. If the administration or the president wants to create a climate of discord and animosity then he or she can. If he or she wants to create an atmosphere where we've just successfully bargained and both sides come to the table in the spirit of collaboration and cooperation then he or she can.

Tracey, an administrator from the community college setting, voiced her belief that with or without a union, it is the president that sets the tone for the college in so far as across campus relationships. Not only did Tracey believe in the power of the president to set the tone for the campus, she insisted that the president of the college or university has the responsibility to communicate with all of the campus constituents in an effort to meet the mission of the college, which is to promote teaching and learning from her perspective.

James voiced that it was his belief that the way in which bargaining is set up in Florida does not support an environment conducive to the cultivation of a positive relationship between faculty and administrators. He also shared a view similar to Tracey in that he too stated that the president is key in setting the tone for the interpersonal campus relationships. He portrayed these sentiments in the following statement:

I think that in Florida unionization and collective bargaining in higher education can only have a negative impact on the faculty-administrator relationship. It's the whole treat them with respect thing. I will go back to what I said before. I am a pro-faculty administrator which was a negative at my old place. So, if you have a pro-faculty administrator, I think the interpersonal relationships [between faculty members and administrators] are fine. The faculty, from my experience when I was involved as a faculty member, it is not so much about getting things as it is 
about getting respect and having a say. The presidents that don't realize that are the ones who get places to go union.

James discussed two of what he perceived to be negative influences on the relationships between faculty and administrators. Regarding the role of the president, he expressed a view similar to that held by Tracey, and cited that the president is one of the major influential factors in setting the tone for the administrator-faculty relationships in an academic institution. Not only did James state that the president held a major role in setting the tone for these relationships, he added that the tone set by the president influences the faculty members' decisions to unionize in an effort to be recognized if there has been a lack of communication and respect displayed by the president of a campus. James also spoke about the bargaining process and the related state statutes as it is set up in Florida as being one of the contributing influences on the definitive splits between faculty and administrative relationships in his institution of higher education.

The influence of the president on the success or demise of the college or university has been the subject of ongoing debate for many years in higher education. Some question the impact of the college president on organizational success contending that the power of the president is restrained in higher education due to the complexity of the roles that the professional faculty members and the board of trustees play in decision making. They believe that due to these restraints, the college or university president virtually has no direct impact on organizational success (Bensimon, Neumann, \& Birnbaum, 2000). Others have argued that the college or university president does indeed play a vital role in promoting the success of an institution stressing the role of the 
context; including leadership has the greatest impact on both the success and the viability of the organization (Lieberson \& O’Connor, 1972; Meindl, 1987; Thomas, 1988).

Study participants, seated at the bargaining table as administrative representatives, reported that they had personally experienced or witnessed a definite "us versus them" mentality between faculty and administration on their campuses. They proposed several factors as being influential in this decisive split, which included the need to strictly adhere to a contract, the nature of bargaining in that it is set up to be a contentious process, the behavior of some of the faculty members seated at the table acting as faculty union representatives for the faculty at large, and the actual negotiation process at their institution. Two administrators shared that the tone for the faculty administrator relationships across campus is set by the college or university president regardless if the faculty is represented by a union or not. One of the administrators interviewed expounded on the importance of the role of the president. He shared that it is the president who is actually a key determinant in the faculty's decision to unionize or not.

The Legitimacy of Faculty Unionization in Higher Education

The majority $(\mathrm{n}=6)$ of the study participants interviewed reported that they had mixed feelings related to the legitimacy of faculty unionization in higher education. Two of the administrators interviewed for this study were absolute in thinking that there is no place at all in higher education for unionization and collective bargaining. One administrator from the university setting was noncommittal in her response. Based on the responses of the administrators interviewed relating to the administrative perspective on faculty unionization, this section was divided into three subheadings: mixed feelings, no place in higher education, and nondescript. 


\section{Mixed Feelings}

Joni, an administrator from the community college setting, reported mixed feelings related to the place of faculty unionization in higher education. She shared that when she first joined her institution while serving as a faculty member, she was an idealist and believed in collegiality to the exclusion of faculty needing to unionize. She did not believe that faculty unionization was appropriate in a higher education setting. In the current contextual climate with the powers to be when she participated in negotiations as a member of the administrative bargaining team, she came to the realization that the union is needed at her particular institution. She expressed this in the following statements:

I think that there is a place for unionization now. But it is not my preference. I really think that we should strive for a perfect world where the faculty wouldn't need to have a union. I was not affiliated with the union when I was a faculty member. I was still living in my perfect world, thinking what happened to professional to professional; to collegiality. I would be much more inclined to join now than in the past if I was a faculty member. But again it saddens me because I think it should be a professional to professional interaction between faculty and administration. In a perfect world collegiality should work. I wish it was a perfect world. If there was a free exchange of ideas, I honestly believe that's the preferred model.

Joni viewed collegiality and collective bargaining in higher education as two distinct methods of communication. She spoke about the need for more discourse and debate to take place in our institutions of higher education several times throughout the interview. 
She went on to say, however, that in today's political context she realized that unionization and bargaining is a necessity at her institution as it is a needed vehicle to give the faculty members a voice.

Tracey was a Vice President for Academic Affairs when she participated in negotiations at her community college. While discussing unionization in higher education, Tracey revealed that she preferred to meet with faculty members individually when and if a problem arose without having to involve others as often happened due to stipulations in the union contract. She continued to say, however, that she did respect the rights of the faculty to unionize if they felt as though they needed protection. Tracey stated:

I have always felt that it is less difficult with a contract because both sides know the rules. It is sometimes very restrictive though. There have been times where I have wanted to cut somebody a break. Without a faculty contract, you can look at things case by case. The union does offer representation though. If you need the union to protect yourself then go for it. If you can do without a union, then do without it.

Tracey preferred a less formal and more individualized way of dealing with faculty members and related issues and/or problems. She recognized that having to work with unionized faculty members and a faculty contract, there was more assurance that everyone would be treated equitably. Additionally, Tracey recognized that the contract really made it easier for administrators as both faculty and administration had a set of ground rules that they were expected to live by. 
Lori, also an administrator from the community college setting, spoke of the positive and negative effects of faculty unionization and collective bargaining. She said:

I think that some of it [unionization and bargaining] is good because everyone is treated fairly. I think you have more safety in joining a union. That's the thing, the union always represented you if needed. Some of it is not good though because there is no wiggle room. There is no way to thank some people. There is no way to give some a little extra.

Lori also shared that as an administrator, she had one particular case in which the union made her job difficult. She had a faculty member who was not good with the students and had damaged some of the community relationships that she had built and fostered over a few years. She felt as though she had to fire the faculty member. She worked with the union for a year regarding this situation. In the end, she was not able to let the faculty member go. Lori has experienced working in an administrative capacity within colleges where there was a faculty union, as well as in colleges where there was none. Overall, she shared that working with unionized faculty members was more difficult than working with faculty members who were not unionized. Lori shared that without a contract and a union not only did she have the needed authority to deal with faculty members in terms of any necessary disciplinary measures, she could also reward those faculty members who excelled in their jobs.

James, another community college administrator, shared that he had struggled with the whole issue of professionals being represented by a union. After working in the setting where he participated in negotiations as discussed for this study, he came to believe that faculty unionization has a place in higher education. Philosophically, he 
shared that he still struggles with the need for professionals to unionize and really wishes that there would not be a need for these academic professionals to be unionized. One of the benefits of unionization on his campus is that the union and the resulting contract had assisted with keeping things above the table and equitable across the campus. Unionization Has No Place in Higher Education

David, an administrator from the community college setting, reported that he personally did not believe in faculty unionization in higher education. He added that he did appreciate that unionization had a time and a place, just not in academia. He felt as though administrators and faculty should instead communicate and partner in a more collegial way. Although David was firm in his conviction that there was no place in higher education for faculty unionization, he did back down a bit in that he added that it is not really the concept of faculty unionization he had difficulty with, it was the negotiation tactics that he had witnessed. David also addressed the value of a strong faculty senate and shared that if the faculty senate was doing what it should be doing, there would be no place for unionization. David shared the following related to faculty unionization in higher education:

I think that unions and collective bargaining had good reason to have gotten started and a purpose in its place and time. It is clear that capitalism is based on exploitation. I can appreciate that. It is not the unionized faculty that I have the issues with, it is the union tactics. I think that unionization in its most positive sense could do what a viable academic senate could do and should do. For the most part, they just want to teach. 
I don't think that unionization has a role in education. I just don't. The fact that it is there and alive and well is an indictment on governance and on those who lead. Because what it says is that they don't know how to engage and collaborate with the very people that they are leading. I think what unionization in its most positive sense could do, a viable academic senate could do and should do. It's all about communication.

David went on to discuss unionization in Florida specifically. He pointed out that the only way that bargaining would be fruitful and equitable is if the faculty had some political might. Without such might they are destined for failure. It is the board of trustees who has the ultimate power if the union has no political might. He expressed this in the following statement:

Unionization is only needed in higher education if the union is willing to do what is necessary. It is political might because some board member has a hair up her a...If that is what you are going to do [unionize], then the only way to do what needs to be done is to strike it with political might. The only recourse that you've got is [pause], what are your options [pause]. You can only fight fire with fire.

David shared that although he is opposed to faculty unionization in higher education, he also has seen that unions are needed to keep things equitable between employer and employee in other sectors. He clarified that personally, he is opposed to faculty unionization based on principle and in Florida he really does not see how faculty unionization could be of any benefit minus the needed political clout and media support. James, an administrator from the community college setting, reported mixed feelings related to the place for faculty unionization in higher education. While he said 
that he struggled with the issue of professional faculty members needing to unionize, he definitely did not think that it was advantageous for faculty members to unionize Florida. In fact, he felt that in the state of Florida, faculty unionization actually had the potential to do more harm than good. He pointed out that the way the negotiation power structure is set up in Florida, including the lack of binding arbitration should faculty declare an impasse with the board of trustees, the administration really has nothing to lose as the board of trustees always sides with administration based upon his experiences. James said the following related to the bargaining process, administration, and the boards of trustees: Here [in Florida] you cannot strike and the boards of trustees have the final say. There is not even a binding arbitration. I ultimately think that in Florida, faculty unionization and collective bargaining can only have a negative impact. It starts because of bad things. If you have a good administration before it starts, it can be okay. But it is so easy to go downhill when you have an administration and a board of trustees that wants to screw the faculty. It is just so easy to do the way it is set up in Florida. Unfortunately, in Florida with the collective bargaining agreement the way it is, if you go to impasse the board of trustees becomes the impartial arbitrator.

James did not hold out much hope for bargaining in Florida after being involved in negotiations at his college where the relationship between faculty and administrators was contentious before bargaining, during bargaining, and after bargaining. He shared that due to the way that the impasse resolution process is set up, with no recommendation being binding and the board of trustees at each institution having the final say, there is really no way that a fair and impartial decision could ever be reached. The board of 
trustees in his experience has always and will always side with administration from his perspective.

In Florida, if an agreement cannot be reached during negotiations between faculty and administrators in public institutions of higher education where there is faculty unionization and collective bargaining, there is a prescribed process that must be followed as put forth by the Public Employees Relations Commission (PERC). Once the commission is notified that impasse has been realized, they request that a mediator be appointed by the Federal Mediation and Conciliations Service to assist the involved parties in reaching an agreement. Mediation is not legally binding. If mediation is not successful or if the involved parties opt not to attempt mediation, PERC then provides both parties with a list of special masters. Both the employer and the bargaining unit are given the opportunity to review the list and to mutually choose a special master. The special master reviews the list of these unresolved issues from both parties, listens to testimony from both parties, reviews any requested documents, and then makes a recommendation on only those issues that were not resolved during bargaining.

Upon the conclusion of this review, the special master then issues a recommendation for each of the contested items. Once the parties receive the recommendations, they each accept or reject the recommendation for each item after a mandated discussion of every item involved. If either party rejects any item, the dispute is settled by a vote of the legislative body of the employer, which in the case of the colleges and universities in Florida is the board of trustees (Public Employees Relation Commission, 2004). In addition to being the legislative body of the university and college; the BOT is the employer of the public higher education employees, including the 
administrators and the faculty members (The 2010 Florida Statutes-447.203, 2010).

Florida statute (2010) also dictates that any discussion between the college or university president or chief executive officer and this legislative body (BOT) is exempt from the sunshine rule and therefore such discussion can take place in a closed session. With discussion taking place before and during bargaining between the chief administrator and the college board, some of the administrators interviewed for this study found it hard to believe that the board would go against the administrative side in bargaining as they have most likely been kept abreast of every issue bargained throughout the process and, therefore, would tend not to side in favor of the faculty on any given issue.

Other factors cited for a genuine absence of any faculty power related to bargaining include the inability of the faculty to strike or threaten such and the lack of media coverage, often a valuable tool for gaining the support of local and political constituencies. A strike by any public employee is specifically prohibited per the Florida Constitution. Actions can be taken against any public employee who does prepare for or conduct any type of activity that could be perceived as a strike by merit that the activity will negatively impact the work of a public employer. Such actions include the suspension or revocation of the bargaining units certification and dues deduction, a hefty fine to be paid by the individual or the bargaining unit to be determined on a case by case basis by the PERC or circuit courts, and not only the termination of a public employee but the imposition of the loss of employment privileges as a public employee in another institution such as being placed on probation for up to 18 months and being held at a salary not to exceed the amount that the employee was being paid at her prior job before 
the strike violation occurred for a period of one year (Public Board Relations

Commission, 2004).

Noncommittal

Mary, an administrator from the university setting, was non-committal in her response when discussing the legitimacy of faculty unionization in institutions of higher education. She said that she did not think that unionization would ever go away, especially due to the current concern over the abolition of tenure. She added that if it were to dissolve after being in existence for over 50 years in higher education, the resulting turmoil would negatively impact the institution and the academy. During the interview, she did pause while talking about a university up north where her friend works and after a few moments spoke about maybe having a strong faculty senate instead of a faculty union, but then she ended her thought with a simple "no." When she addressed the legitimacy of faculty unionization in higher education, Mary shared the following:

I don't see faculty unionization going away. I think that there is enough concern about tenure. I would be surprised if unions go away. But anything is possible. I don't know how you would get out of it once you're in it. Getting rid of the union would be an absolute betrayal now, if we [the administration] said we don't want it here now. I don't know if we could. You know some of the stronger schools don't have a union.

Mary did not share any personal opinions as to whether or not faculty unionization and collective bargaining had a legitimate place in higher education. She did share that she believed unions are here to stay and any attempt to dissolve an existing union would be viewed as a betrayal to the faculty members by the administration in her opinion. 
A majority $(n=6)$ of the study participants interviewed reported that they had mixed feelings related to faculty unionization and its place in higher education. Two of the administrators interviewed for this study were absolute in thinking that there is no place at all in higher education for unionization and collective bargaining. One administrator from the university setting was noncommittal in her response. While addressing the question of whether or not they felt that faculty unionization has a legitimate place in institutions of higher education, a few of the study participants talked about preferring a more collegial relationship with faculty members. Birnbaum (1980) defines collegiality related to bargaining in the unionized academic setting as "the establishment of interpersonal and intergroup relationships based upon a mutual commitment to professional values, civility in interactions, and faculty influence in the decision-making process" (Birnbaum, 1980, p. 16). It is the absence or the presence of collegiality that sets the tone for across campus interpersonal relationships and actions based on the individual's or the group's (in the case of this study, the higher education administrator's) perspective.

In one study, faculty members were asked to define collegiality. They responded that overall collegiality involves being treated with and treating others with respect, possessing the ability to work with others and carry out needed responsibilities, feeling valued and respected at work, and feeling valued by the institution (Balsmeyer, Haubrich, \& Quinn, 1996; Fogg, 2006). The American Association of University Professors (AAUP) discouraged the academy from looking at collegiality as a separate performance measure to be used when evaluating faculty members. The AAUP advised members of the higher education academy that though collegiality in its most basic sense involves the 
premise of a partnership, other connotations may also be implied including compliance and homogeneity neither of which would be conducive to an atmosphere that promotes discussion, dialogue, nor debate (Connell \& Savage, 2001).

Although the definitions of collegiality vary, all included some reference indicating that collegiality involved some degree of commitment on the part of all involved. In this study, the administrators who voiced a sense of discomfort while participating in bargaining were concerned that they would be perceived as the "bad guy" on campus by the faculty members. This perception will play a key role in their participatory behaviors and in their attitude toward faculty in accordance with the theory of symbolic interactionism.

Summary of Profiles and Descriptive Categories

The study participants interviewed for this study include administrators from the community college and university settings in southeast Florida. A brief profile of each of the study participants was offered. Each of the participants was described using an assigned pseudonym involving a first name not at all related to the participant. This same pseudonym for each of the participants was used whenever referring to that particular administrator throughout this dissertation. The participants include a president, two academic vice presidents, two provosts, three academic deans and a department chair.

Five major descriptive categories were derived from the study interviews. The five categories that emerged included reasons for wanting to be an administrator, the administrative role in collective bargaining, preparation for negotiations, the relationship between faculty members and administrators in the institutions of higher education that were included in this study where the faculty was unionized and both faculty and 
administrators were involved in bargaining negotiations, and administrative thoughts about the legitimacy of faculty unionization in higher education.

Recommendations for practice as a higher education administrator working with unionized faculty members and participating in collective bargaining negotiation sessions were deliberated, along with recommendations for future studies dealing with unionization and collective bargaining in higher education and discussed in the next chapter. 


\section{CHAPTER V}

CONCLUSIONS: FINDINGS, IMPLICATIONS, RECOMMENDATIONS

The purpose of this study is to add information to the existing body of literature related to higher education by identifying some of the contemporary themes and concepts related to faculty unionization and the collective bargaining process, as well as the resulting dynamics in terms of the interpersonal relationships between faculty and administrators from what Bogdan and Biklen (2007) refer to as the native's point of view which in the case of this study was the higher education administrator who worked with unionized faculty members and represented the administrative bargaining team at the negotiation table.

Five of the categorical descriptive themes inclusive of the major study findings were discussed as related to the questions that guided this study. These themes included: (a) the reasons that the study participants entered higher education administration and collective bargaining negotiations, (b) expectations of administrators related to collective bargaining and working with unionized faculty members, (c) the negotiation preparation phase of bargaining, (d) the impact of bargaining and unionization across the higher education academy, and (e) the legitimacy of faculty unionization in higher education.

It is the hope of this researcher that the answers to the research questions, guided by the theoretical framework of symbolic interactionism, will assist the reader as well as the study participants in understanding more about the negotiation process, faculty unionization, and the interpersonal relationships between faculty and administrators. The research questions that guided this study included: 
1. What are the administrators' perceptions of the collective bargaining process and faculty unionization in higher education after having participated in both roles?

2. What are the administrators' perceptions of the factors of unionization and collective bargaining in regards to the interpersonal relationship between faculty and administration?

The theoretical framework, provided by symbolic interactionism and utilized to guide the formulation of the research questions and the study interviews, suggests that individual and group experiences and events are open to individual interpretation. One's resulting perception of the event was influenced by interacting with others and observing how they act toward the event and each other. These meanings are construed, applied and modified through an individual and dynamic interpretive process (Blumer, 1969). It is this unique individual perspective that defines how that particular individual or group of individuals will act toward related or similar events, such as working with unionized faculty members and participating in the collective bargaining process. The process of interpretation and response is dynamic and open to revision or change based upon the continuous acquisition of new information assimilated by an individual or a collective group of individuals related to an event or phenomenon. Context, including leadership, politics, and economics plays a critical role in this interpretation process, as well as in the possibilities for responses and actions taken in regard to a particular phenomenon (Stryker, 1980).

Topics addressed in Chapter 5 include: (a) a brief overview of this study, (b) a discussion of the findings, (c) the implications of each of the study findings, (d) 
recommendations related to each of the findings based on the study findings and a literature review related to unionization, collective bargaining, and higher education administrators, (e) recommendations for theory and research, and (f) a summary of the chapter including the researcher's concluding thoughts concerning this study.

\section{Study Overview}

A surge in enrollment in institutions of higher education that was in part due to the favorable post-World War II economic conditions and the call for social equity in the United States in the early 1960s led to a substantial increase in growth in institutions of higher education (Thelin, 2004). The fast and vast increase in enrollment called for a dramatic increase in facility size, number of faculty needed, diversity of faculty needed, and a multifaceted specialization of services. At the same time, the higher education academy experienced institutional and professoriate fragmentation (Duryea et al., 1973; Garbarino \& Aussieker, 1975). Faced with an opportunity to explore improved financial and fringe benefits and the need to address the separation of faculty and administration with the increasing bureaucratic styles of management being brought into these institutions in an effort to manage the size and fragmentation of the academy, faculty members began to unionize and collective bargaining in higher education came to a realization in the early 1960 s.

The stability of faculty unionization and collective bargaining in our public institutions of higher education is now one of the foremost contemporary issues faced by the academy today. The current political and socioeconomic climate have brought about many challenges for our higher education institutions including an attempt to dissolve faculty unions at public institutions of education as was most recently seen in Wisconsin. 
Slaughter and Rhoades (2004) described a shift from academic capitalism to academic corporatization. Shumar (1997) compared today's institution of higher education to a factory composed of managers, employees, and consumers driven by the call for economic efficiency. Enhanced efficiency measures include quick turnaround times, lack of shared governance, and a bureaucratic organizational re-structuring. In response to the increased competition and a finite pool of financial resources taking place in many of these institutions, the chief academic officers in these institutions are faced with multiple realities and allegiances.

Recognizing the protection and benefits that have come about for unionized faculty members, it is imperative that one takes the time to examine the level of involvement and the possible influence that administrators may have related to faculty unionization and collective bargaining. Duryea et al. (1973) recognized that faculty members were a crucial constituent in higher education. They called on higher education administrators to realize that they are accountable to faculty members. Based on the theory of symbolic interactionism (Blumer, 1969; Mead, 1934; Stryker, 1980), it is the perceptions of these higher education administrators, as well as their relationships and all of the related dynamics with each other and faculty members, that impact their attitudes and behaviors while working with unionized faculty members and participating in the collective bargaining process.

In an effort to better understand what it is like to work with unionized faculty members and to be involved in collective bargaining negotiations as a member of the administrative bargaining team, the purpose of this study was to explore and explain the perceptions of nine higher education administrators, who have worked with unionized 
faculty members and actively participated in union negotiations. Appreciating that there has not been much written from the administrative perspective, a qualitative case study approach was utilized. The motivation for this study came from this researcher's personal and professional desire to gain insight and understanding into the phenomenon of unionization and collective bargaining from the viewpoint of experienced higher education administrators.

The use of a qualitative case study approach allowed for an in-depth analysis of the multiple realities of the participants interviewed (Bogdan \& Biklen, 2007). In the instances of working with unionized faculty members and participating in the collective bargaining process, there was a limited amount of published research available from the perspectives of those college and university administrators who have directly participated with these conditions and events. The participants for this study included a small, purposive sample of nine higher education administrators, who have worked with unionized faculty members and have represented administration at the bargaining table during negotiations. Purposive sampling was utilized to assure the researcher, as well as the reader, that the individuals interviewed had the necessary knowledge and experience with regard to faculty unionization and collective bargaining. Study participants were recruited from two colleges and two state universities in Florida. These institutions are similar in that they are all multi-campus, urban, public institutions that serve a culturally and ethnically diverse student population. All of these institutions also have a board of trustees that is appointed by the governor of the state. The institutions differ in their focus as related to research and accessibility, as well as faculty credentialing requirements. Although the overall general descriptions of these contexts remained the same throughout 
this dissertation, the real names and identities of the study participants and institutions were not disclosed. Each participant was assigned a pseudonym that was used to identify that participant throughout the study.

Study participants were identified through the personal knowledge of this researcher, an administrator at a local college and a graduate student at a university where collective bargaining occurs. Additional study participants were recruited based upon recommendations from interviewed participants. Candidates were selected based on their experience as participants in the collective bargaining process as administrators and their willingness and ability to communicate their experiences, attitudes and beliefs relating to collective bargaining and faculty unionization.

The primary method of data collection was semi-structured face-to-face interviews. Follow-up phone interviews were conducted as needed. All of the initial interviews with each participant were conducted face-to-face and audio recorded with the permission of each of the participants. Each participant was afforded the opportunity to conduct the second interview either face-to-face or via phone if necessary and/or desired by the participant. There were four follow-up interviews conducted upon the request of the researcher. These follow-up interviews were done to clarify some of the information obtained from the participants during the initial audiotaped interviews after having listened to the audiotapes several times. A modified analytic induction approach to data collection and analysis was employed. This method allowed for the simultaneous collection and analysis of data, thereby affording the researcher the opportunity to modify, add, or delete questions as necessary with each progressive interview (Bogdan \& Biklen, 2007). 
Higher education administrators who participated in this study included five female and four male higher education administrators, who had been in their current positions for an average of 5.4 years. The administrators interviewed for this study were employed in the higher education arena for an average of 27.2 years. Eight of participating administrators had previously served as faculty members for an average of 8.6 years. The average reported age of the study participants was 50-59 years. The youngest participating administrator was between $40-49$ years of age and the oldest was between 60-69 years of age. The overwhelming majority of study participants $(n=7)$ held Ed.D. degrees and one participant held a Ph.D. in her specific discipline. At the time of their participation in bargaining as discussed in this study, one of the participants served as president, two as vice presidents, two as provosts, three as academic deans, and one as department chair.

Symbolic interactionism calls for the understanding that all human experiences are actively chosen and uniquely interpreted by each individual. It is the interpretation of an event, based upon one's relationships and experiences with others, that fosters the determination of one's perspective and resulting behavior while participating in that event (Blumer, 1969). In order to best understand how one interprets an event or a phenomenon, the researcher must gain insight into the participant's experiences, relationships, and thought processes preceding that interpretation (Blumer, 1969; Bogdan \& Biklen, 2007). Symbolic interactionism also recognizes that self is defined through interacting with others while coming to see one's self as others do (Mead, 1934). These basic tenets of symbolic interactionism were taken into account when formulating the interview guide, interviewing the participants, and analyzing the study data. Based on the 
theory of symbolic interactionism the questions that guided this qualitative research study addressed the perceptions of the higher education administrators interviewed in regards to unionized faculty members, collective bargaining negotiations, and the elements of both with regard to the relationship between faculty and administrators on their campuses.

Upon the completion of each interview, the researcher listened to the taped audio recording of the interview several times and took notes that included any questions that required follow-up or the need to formulate new questions for subsequent interviews. Once the interview for each participant was completed in an effort to further immerse herself in the data and to protect the confidentiality of the administrative participants, this researcher transcribed all of the audio taped interview data and saved it as a Word document.

Once all of the interviews were completed and the data were transcribed field notes, thoughts and observations were added. Once all of the data was reviewed and analyzed, the process of data display and reduction was begun. Data analysis entailed the gathering and organizing of all of the researcher's notes and interviews, sorting the data into smaller units based on similarities and differences while searching for themes based upon the study results and the available existing literature related to the topic under investigation, and then synthesizing the units and looking for the overall study implications. Once the study implications were identified by the researcher, recommendations for the higher education administrative bargaining team members, as well as for faculty union representatives, were made based on the study findings, the theory of symbolic interactionism, and the available published data related to collective bargaining, faculty unionization, and administrators in higher education. During this 
phase of the study, this researcher focused on her primary responsibility, which was to represent the study participants. This is different from identifying with the participant or endorsing everything that the participant says (Miles \& Huberman, 1994). Although the data were informally analyzed by the researcher throughout the study, the final analysis did not begin until all of the data had been collected, read and re-read while searching for any similarities and differences between interviews.

There were five descriptive themes identified by this researcher after a thorough review of the audio taped interviews and resulting transcripts. These themes included: (a) the reasons that the study participants entered higher education administration, (b) the administrative role in collective bargaining and working with unionized faculty members; (c) the negotiation preparation phase of bargaining, (d) the impact of bargaining and unionization across the higher education academy, and (e) the legitimacy of faculty unionization in higher education.

\section{Discussion of Study Findings}

Patton (2002) posed four questions for the qualitative researcher to explore before attempting to explain and interpret research findings. These questions look at the solidity and the sustainability of the study findings, the degree to which the study findings are consistent with the current body of knowledge related to the topic in either supporting or refuting the available findings, the extent to which the study findings answer the questions that guided the study, and the degree to which the study findings increased the overall level of understanding related to the phenomenon studied. Related to the solidity and sustainability of the study findings, the theory of symbolic interactionism is applicable as it is based on the importance of understanding and appreciating the unique 
perspective of the individuals involved in the activities related to collective bargaining and working with unionized faculty members (Blumer, 1969; Mead, 1934).

The five study findings related to the descriptive themes that were derived from the reports of the administrators who participated in this study included: (a) to be an effectual leader and administrative representative at the bargaining table, one must have an understanding of what it is that faculty does and how they go about doing it, (b) the administrators experienced role ambiguity and role strain related to their perceptions that there was a lack of communication between them and other senior administrators and board members and a lack of support from the senior administrators and board members, (c) the administrators perceived that their institutions offered them little or no training related to collective bargaining negotiations and labor laws, (d) the administrators felt that faculty unionization and collective bargaining resulted in a divisive split between faculty and administrators, and (e) faculty bargaining was ineffectual in Florida. The findings from this study were listed and discussed individually, along with the implications of such, and the recommendations related to each implication based on the research questions used to guide this study, the information gained from the study participants, the available published information, and the theory of symbolic interactionism.

Pre-requisite to Being an Effective Administrator on the Bargaining Team

The first study theme encompassed the reasons that the administrators interviewed chose to go into higher education administration and how they ended up at the bargaining table as a member of the administrative negotiating team. Eight of the administrators, who participated in this qualitative multi-case study, began their academic careers as 
faculty members. The related study finding was that the administrators interviewed, based on their experiences while serving in an administrative capacity at their academic institutions and on their encounters at the bargaining table, overwhelmingly recognized that to be an effectual leader and administrative representative at the bargaining table, one must have an understanding of what it is that faculty does and how they go about doing it.

One of the implications of this finding was that it seems as though the administrators who have worked with unionized faculty members and participated in collective bargaining negotiations perceive that it is necessary to have served as a faculty member in order to have a first hand, clear understanding of the role of the faculty member in terms of teaching, learning, research, and service, as well as all of the obligations and needed resources related to each of these duties. A second implication related to this study finding was that perhaps those administrators, who lack a clear understanding of the faculty role and working conditions, may lack a clear understanding of the issues and related practicalities being brought to the negotiation table. This lack of understanding may result in a variety of negative perceptions on the part of both administrators and faculty members both present and not present at the bargaining table. These perceptions, in turn, will influence the overall behavior of these constituents related to bargaining, relationships, and working with unionized faculty members. Mary, an administrator from a south Florida university, shared that after working with unionized faculty members and after participating in negotiations as an administrative bargaining team member, it was her perception that unless one has served as a faculty member, one cannot really understand the issues and needs inherent to this role, which will cause that administrator to become "jaded" toward faculty members and lack respect for them. A 
third and final implication related to this study finding was that those administrators (including the members of the boards of trustees) who choose the members of the administrative bargaining team did not take into consideration the expertise of the administrators who were chosen to represent the administrative bargaining team and of the faculty in regard to their own jobs.

There was much information in the literature regarding administrators related to who they are and how they came to be higher education administrators. Many of today's academic leaders have evolved into their current leadership roles by climbing what is known as the normative ladder. The normative ladder leading to higher education administrative roles includes a progression from faculty, to chair, to dean, to provost or vice president, and then ultimately to college or university president (Cejda, McKenney, \& Burley, 2001). This normative progression has afforded a sense of security in academia in that it has allowed for the acquisition of skills and attributes needed for working with other administrators and faculty members across the campuses. Some of these needed skills and attributes included understanding the college and university mission, effective communication and listening skills, the ability to write effectively, organization and time management, faculty and curriculum development, and understanding mediation and negotiation, as well as an awareness of your constituent base, their roles, and needs (Brown, Martinez, \& Daniel, 2002).

Cejda et al. (2001) found that over half of the chief academic officers in the public community college and colleges were internal candidates. Over $80 \%$ of them started their careers in higher education as faculty members. The average age of today's college president is 56 years of age, and it has been estimated that over three-quarters of these 
current college presidents will retire by 2012 (Hull \& Keim, 2007). In addition to the predicted mass exodus of today's college presidents, colleges and community colleges will experience a major turnover of their chief academic officers over the next few years. In 2002, it was reported that the average age of the chief academic officer was 53 years (Anderson et al., 2002).

With approximately two-thirds of these colleges being affected by large changes in leadership having unionized faculty members (Lovell \& Trouth, 2002; Murray \& Murray, 1998), it is crucial that we recognize the upcoming turnover in academic leadership and the perceptions of our current academic leaders related to faculty unionization, the collective bargaining process, and factors of unionization related to the relationship between faculty and administrators. With this expected turnover, our current administrators will be the ones mentoring and introducing these new higher education leaders to academia, their particular institutions inclusive of the history of such and the associated traditions, working with unionized faculty members and a collective bargaining contract, and the negotiation and collective bargaining process. These introductions, in accordance with symbolic interactionism, will play a role in how the future academic leaders will perceive and engage in these activities (Blumer, 1969).

The first study finding indicated that the administrators interviewed overwhelmingly perceived that to be an effectual leader and administrative representative at the bargaining table, one must have a thorough understanding of what it is that faculty does and how they go about doing it. Based on this finding, it is this researcher's recommendation that when choosing a representative for the bargaining team, the college president and/or leaders of the administrative bargaining team, choose an 
administrator who has served as a faculty member prior to assuming an administrative position. Not only will this past history of serving as a faculty member assist the administrator in understanding the expectations and the needs of faculty members, it will also provide the administrator with respect for the faculty members at large and at the bargaining table, as well as assist in the understanding of the faculty contract and the related impacts of the faculty issues being brought to the table for negotiations.

\section{Role Ambiguity and Role Strain}

A second study theme that emerged was the administrative role in collective bargaining and working with unionized faculty members. The study finding related to this theme was that the administrators participating in this study experienced role ambiguity and role strain related to the lack of communication and support received from other lead administrators on the bargaining team, college presidents, and from the boards of trustees. Study participants shared that they were not clear as to why they were chosen to be an administrative representative on the bargaining team, their role as a team member, and the inherent duties related to being a representative for the administrative bargaining team. Two of the study participants shared that they felt as though they were seated at the table to be put on display as a window dressing as they were not told what their role was as a member of the administrative bargaining team, nor were they given any information related to the issues to be negotiated or the available institutional resources including the amount of money available for faculty raises. One study participant shared that when she asked for a hard copy of the collective bargaining agreement, she was told not to worry about that. The lack of communication and sharing of information on the part of the chief negotiator for the administration was viewed as a 
possible bargaining strategy, the fact that collective bargaining was a low priority for some higher up administrators at their institutions including members of the boards of trustees, anti-union motives on behalf of some of the members of the boards of trustees, or a factor of a dysfunctional administration who did not communicate with those chosen to represent administration at the bargaining table. The resulting role ambiguity contributed to the participating administrators reports of feeling frustrated over not being needed or utilized while seated at the bargaining table and not being able to engage in any type of meaningful dialogue with members of the faculty bargaining team.

This finding was supported in the literature. Role ambiguity is often the result of the higher education academic administrator being pulled in two different directions as a result of serving both faculty and administration. In the case of collective bargaining, both parties being served often have conflicting interests. Role ambiguity often results in ambivalence on the part of the administrator, especially when there are no clear role assignments or role expectations defined and assigned by the top level administrators (Wild, Ebbers, \& Shelley, 2003; Wolverton, Wolverton, \& Gmelch, 1999).

Role strain, as defined by social science theorists, is experienced when one has trouble fulfilling expected tasks due to a lack of consensual commitment or an easy integration between the expected task and one's philosophical beliefs related to how they should be or act in a given situation with a given population (Goode, 1960). Role strain can thus result when one is given an assignment and directed to carry that assignment out without the needed resources, including organizational commitment and support in terms of resources and administrative feedback. 
The administrators interviewed for this study reported that they perceived that sitting at the bargaining table was unnecessary, confusing, and not in their best interest or in the faculty's best interest. This finding was significant in terms of the total number of participants who expressed these feelings. All of the administrators interviewed shared that if given the choice, they would choose not to participate in negotiations again.

One implication of this study finding was that it seems as though there was not much communication between the higher up administrators and those administrators assigned to the administrative bargaining team. A second implication was that perhaps due to a lack of support from the higher up administrators involved in the decision making process at the colleges and universities, including the presidents and the members of the boards of trustees, the administrative representatives seated at the bargaining table were not really empowered to make any decisions or speak on behalf of administration.

In light of this study finding related to the role ambiguity experienced by all of the participants from this study, the related literature, and the research questions that were used to guide this study, this researcher's recommendation was to encourage the top level administrators to meet with the members of the administrative bargaining team and to clearly articulate the roles and responsibilities associated with being a member of this team. Additional issues that should be addressed by these top level administrators with the administrative representatives before negotiations begin includes; contractual issues, negotiation techniques to be utilized, a history of negotiations at the institution, administrative issues related to the current union contract, and the institution's current budget status. 
A second recommendation was related to the reported perceived lack of institutional support including the support of the lead administrative negotiation team members, the college presidents, and the members of the boards of trustees, as well as the reported perception that serving on the administrative negotiation team often made the academic administrators appear to be the bad guy in the eyes of the faculty. This recommendation was based on the feedback from three of the study participants who disclosed that though they were really not needed during the actual negotiation sessions, but their participation behind closed doors was essential as many of the administrators who were seated at the table and were the key decision makers lacked a clear understanding of the academic and faculty issues that were often brought to the table. The related recommendation was to utilize some the academic administrators who had previously served in faculty roles and currently working closely with the faculty members and students as consultants on an as needed basis.

Overall, it seems as though there needs to be more communication, support, and trust between the administrators seated at the negotiation table and the higher level administrators and members of the boards of trustees, who are ultimately the final decision makers in our south Florida public institutions of higher education.

\section{Inadequate Preparation for Collective Bargaining Negotiations}

The third study theme was negotiation training and preparation. The study finding relative to this theme was that the higher education administrators interviewed for this study overwhelmingly perceived that their institutions offered them little or no training related to collective bargaining negotiations and/or labor laws before they were assigned to the administrative bargaining team. One implication of this finding was that it seems as 
though institutional leaders do not care much about bargaining with faculty until they are faced with having to deal with it. Secondly, perhaps administrators are chosen to participate in collective bargaining negotiations not because they understand bargaining, negotiations, and the law, but perhaps for another reason that was not determined by this study.

An overwhelming number of the study participants stated that they never received any type of training before they participated in negotiations and cited that training and/or mentoring would have been extremely useful. A few of the administrators interviewed looked for resources to help them prepare for bargaining, however, they were unable to find literature specifically related to what they were interested in, which was bargaining expectations, the negotiation process in higher education, and how to handle the discomfort once bargaining sessions became heated. The administrators interviewed also stated they did not want to attend what they referred to as useless training sessions. They described these "useless" sessions as being void of practical, hands-on, lived experiences, too theoretical in nature, or led by someone who was too far removed from academia to be able to give any real, applicable advice to higher education administrators, who worked with unionized faculty members and directly involved in union negotiations.

This lack of negotiation training was supported in the literature. In one study looking at leadership training, Hull and Keim (2007), leadership training initiatives focused on team building, institutional purpose, values, culture, mission, budgeting, funding, and governance over $60 \%$ of the time. Conflict resolution was focused on under 50 percent of the time, along with crisis management and the role of the board of trustees. 
Formal educational programs leading to a discipline specific Ph.D. or an Ed.D. with a focus on higher education and leadership have gained momentum over the past few decades. Over the past 50 years, the number of higher education administrators holding doctorate degrees has risen over $30 \%$ and is estimated to be at approximately $80 \%$ (Hull \& Keim, 2007). While these formal programs are often strong in history, theoretical foundation and research strategies, some complain that they are weak in offering real-life practical advice. Reports from graduates of some of these programs focusing on higher education and leadership referred to the material that was presented in many of their graduate classes that focused on conflict resolution and communication as being outdated and impractical (Brown et al., 2002; Hull \& Keim, 2007).

The researcher's recommendation for practice related to this third study finding, and based upon the information from the study interviews and the related literature was to offer educational opportunities in-house while bringing in needed experts to discuss their practical experiences and tips for bargaining, as well as state and federal statutes related to labor and negotiations. Additionally, invite members of negotiating teams both administrators and faculty members from local and state-wide institutions of higher education for panel discussions to share experiences about what has worked, what has not, and the current state and federal issues that impact higher education, leadership decisions, and faculty issues related to bargaining.

\section{Us Versus Them}

The fourth theme that emerged after interviewing the nine administrators, who shared their perceptions associated with their experiences working with unionized faculty members and participating in collective bargaining negotiations, was the impact of the 
factors of bargaining in relationship to the higher education academy. The study finding that emerged from this theme was that the administrators interviewed perceived that faculty unionization and collective bargaining had resulted in a resolute split between higher education faculty members and administrators at their institutions creating an "us versus them" mentality. They proposed several issues as being related to some of the factors involved in the decisive split between faculty and administration on their campuses including the need to strictly adhere to a contract, the nature of bargaining in that it is set up to be a contentious process, the behavior of some of the faculty members seated at the table acting as faculty union representatives for the faculty at large, the actual negotiation process at their institution, and the change in the decision making hierarchy that took place when both administration and faculty were seated at the table to engage in bargaining as equals which was quite different from the day to day relationship between the two parties where faculty members were more in an advisory role with the administration having the final say.

Negotiation has been defined in various ways by academicians. Many of the definitions include a reference to the involvement of two parties who hold opposing views and often have opposing interests and need to reach some sort of agreement through bargaining (Birnbaum, 1980; Lewin, 2005; Zagelmeyer, 2005). DelFavero (2003) discussed some of the inherent difficulties in the faculty-administrator relationship in higher education citing that both groups have different roles, professional orientations, and allegiances. Birnbaum (1980) defined collegiality related to bargaining in the unionized academic setting as "the establishment of interpersonal and intergroup relationships based upon a mutual commitment to professional values, civility in 
interactions, and faculty influence in the decision-making process" (Birnbaum, 1980, p. 16).

From the perspectives of the participants who were interviewed for this study, the factors attributing to this decisive split between faculty and administration in higher education has ascribed to a less collegial atmosphere on their campuses. In one study, faculty members were asked to define collegiality. They responded that overall collegiality involved being treated with and treating others with respect, possessing the ability to work with others and carrying out needed responsibilities, feeling valued and respected at work, and feeling valued by the institution (Balsmeyer, Haubrich, \& Quinn, 1996; Fogg, 2006). Although the definitions of collegiality vary, most include some reference indicating that it involves some degree of commitment on the part of all involved.

The implication of this study finding was that it seems as though there is a lack of trust and discourse between faculty and administration at the bargaining table. One reason for this may be related to the way in which bargaining was set up, in that it was perceived as a contentious process, perhaps in part related to differences in communication styles, roles, and responsibilities of the parties involved. Addressing the preferred difference in the communication styles by faculty and administrators, Jette (2005) examined negotiation tactics of teachers and administrators. He noted that administration favored the use of dialogue at the bargaining table while the educators preferred debate.

In accordance with this study finding, the related literature available, and the theory of symbolic interactionism, recognizing the differences in the preferred type of 
negotiation communication between faculty and administrators, as well as between individual team members seated at the negotiation table, a recommendation was made by this researcher to cautiously re-visit the possibility of returning to centralized bargaining while keeping in mind the current political context here in Florida and noting the importance of the need to obtain feedback from both faculty members and administrators who were directly involved with centralized bargaining in the past and currently involved with decentralized bargaining.

The decentralization of bargaining occurred in Florida approximately 11 years ago. The statewide Board of Regents was replaced with a separate board of trustees for each of the eleven state university systems (SUS) in Florida in 2000-2001 after it was passed by Florida voters while Governor Jeb Bush was in office. With the dissolution of the Board of Regents, who bargained with administrators and faculty members from the SUS in Florida, bargaining was decentralized and administration from each of the universities negotiated directly with faculty members on their individual campuses. Decentralized bargaining, while able to afford an opportunity to meet the needs of campus specific constituents and to include more opportunity for in-house participation, brings with it the potential conflict between the involved parties as was cited by two of the study participants from the university setting.

Two of the administrators interviewed for this study voiced their belief that statewide, centralized bargaining buffered administration from being the bad guy with faculty members as they were not directly involved with the actual bargaining. Instead, the spokesperson for the universities present at the table was a member of the Board of Regents. Mary, an administrator from the university setting shared her experience with 
centralized bargaining and the factors of such on the interpersonal relationship between the faculty and administrators at her university. She said that with centralized bargaining, "I don't think that there was a lot of tension at the time. It was like, it's up there, and it is really the Board of regents that you were really bargaining with.” While others agreed that centralized bargaining provided a venue for placing blame "up there" with bargaining failures, centralized bargaining was not without its problems. With centralized bargaining, consultation was permissible between chapter leaders and top administrators. Some stated this may have influenced the bargaining issues that were important for one of the 11 universities involved to take precedence during negotiations to the exclusion of other issues that may have been of notable importance to another university (Fiorito \& Gallagher, 2006). Although not particular to higher education, others have argued that negative aspects of centralized bargaining include the size of each of the involved institutions was not taken into account, the uniqueness of the institution was not a factor in bargaining, and the special needs of the institute include the need for special programs, and/or faculty considerations were not taken into account (Ramamurti, 2001). An additional concern related to centralized bargaining was the fact that any pay raises were entirely subject to the availability of state funds.

While this recommendation is based upon the feedback received from the administrators involved in this study and the literature related to bargaining and administration, this researcher has proposed a cautious revisiting of centralized bargaining with an understanding that much feedback is needed from both faculty and administration before taking any steps to actively pursue this return to centralized bargaining. 
The Faculty Bargaining Process in Florida is Ineffectual

The final study finding that emerged from the fifth study theme, the legitimacy of faculty unionization in higher education, was that the administrators interviewed perceived faculty unionization was more or less a waste of time in Florida due to the way the whole impasse process is set up, the lack of media coverage, the lack of any political might on behalf of the union, and the inability for faculty members to strike or to call for a strike.

In Florida, if an agreement cannot be reached in public institutions of higher education where there is faculty unionization and collective bargaining, there is a prescribed process that must be followed as set forth by the Public Employees Relations Commission (PERC). Once the commission is notified that an impasse has been realized, they request that a mediator be appointed by the Federal Mediation and Conciliations Service to assist the involved parties in reaching an agreement. Mediation is not legally binding.

If mediation is not successful or if the involved parties opt not to attempt mediation, PERC then provides both parties with a list of special masters. Both the employer and the members of the bargaining unit are given the opportunity to review the list and to mutually choose a special master, who makes a recommendation on only those issues that were not resolved during bargaining after reviewing the list of unresolved issues, listening to testimony from both parties, and reviewing any requested documents. Upon the conclusion of this review, the special master then issues a recommendation for each of the contested items. 
Once the parties receive the recommendations, they each accept or reject the recommendation for each item after a mandated discussion of every item involved. If either party rejects any item, the dispute is settled by a vote of the legislative body of the employer, which in the case of the colleges and universities in Florida is the board of trustees (Public Employees Relation Commission, 2004). In addition to being the legislative body of the university and college, the board of trustees is the employer of the public higher education employees including the administrative team and the faculty (The 2010 Florida Statutes-447.203, 2010).

Florida statute also dictates that any discussion between the college or university president or chief executive officer and the legislative body (the board of trustees) relative to collective bargaining is exempt from the sunshine rule and, therefore, such discussion can take place in a closed session (The 2010 Florida Statutes-447.605, 2010). With discussions taking place before and during bargaining between the chief administrator and the college board, some of the candidates interviewed found it hard to believe that the board would go against the administrative side in bargaining as they have most likely been kept abreast of every issue bargained throughout the process. Therefore, the board would tend not to side in favor of the faculty on any given issue.

Another factor cited for a genuine absence of any faculty power related to bargaining in Florida was the inability of the faculty to strike or threaten such. A strike by any public employee is specifically prohibited per the Florida Constitution. Actions can be taken against any public employee who prepares for or conducts any type of activity perceived as a strike by merit that the activity will negatively impact the work of a public employer. Such actions include the suspension or revocation of the bargaining units 
certification and dues deduction, a hefty fine to be paid by the individual or the bargaining unit to be determined on a case by case basis by the PERC or circuit courts, and not only the termination of a public employee but the imposition of the loss of employment privileges as a public employee in another institution, such as being placed on probation for up to 18 months and being held at a salary not to exceed the amount that the employee was being paid at her prior job before the strike violation occurred for a period of one year (Public Board Relations Commission, 2004).

The implication of this study finding was that the administrators may perhaps view collective bargaining in strictly legal terms. When viewed solely from this perspective, administration does have all of the power in that the board of trustees has the final say and the faculty at public institutions of higher education in Florida cannot strike. A recommendation for administrators in public institutions of higher education in Florida related to this finding and the implications of such was to suggest that administrators involved in collective bargaining negotiations not view negotiations from a strictly legal perspective. Other related considerations associated with unionization, bargaining, and impasse need to be considered including the cost of impasse to the college both financially and in terms of its reputation in the academic community. Financially, if resources are re-allocated to cover the cost of all that is involved should an impasse be declared, the result could be the lack of available funding for other areas including administrative and faculty discretionary raises. In terms of the reputation of an academic institution, one does not want to be known as the president or the administrator who was involved in negotiations where there were all those problems between faculty and administration. Not only might this have an effect on the recruitment of new faculty 
members and administrators, it may also impact one's chance of being a selected candidate for other jobs outside of one's institute in academia.

\section{Additional Recommendations Related to Theory and Research}

Social exchange theories related to perceived organizational support, role conflict and role strain cautioned employers those employees who lack a clear understanding regarding their particular roles within the organization and who feel undervalued were prone to experiencing role strain and role ambiguity (Cohen \& March, 1974; Eisenberger, Huntington, Hutchison, \& Sowa, 1986; Goode, 1960). Higher education administrators are often caught in the middle in regards to their allegiances to both faculty and administration, often making them more susceptible to job burnout and turnover, withdrawal and apathy related to the workplace, and lower levels of customer care and subordinate support and leadership based on their perceptions. These perceptions related to the level of organizational support they experience, their understanding of their assigned roles in the institution, and the alignment of their assigned duties with their philosophical beliefs about how they should act as administrators and colleagues (Eisenberger, Armeli, Rexwinkle, Lynch, \& Rhoads, 2001; Shanock \& Eisenberger, 2006; Wolverton, Wolverton, \& Gmelch, 1999). In congruence with the theory of symbolic interactionism, all of these perceptions and beliefs are based on individual perceptions formed after participating in different events and interacting with others (Stryker, 1980).

Ray (1989) described health care organizations and the interdependent relationships and complexities inherent to such while focusing on the perceived antithesis of caring amongst the different organizational constituents. Her theory of bureaucratic 
caring called for the recognition that every subculture within the organization, including those nurses providing the direct bedside patient care as well as the top administrator, does indeed care about the organization and the well-being of the organization. Each of the subcultures and each of the individuals involved, however, will have a unique focus and perspective (Ray, 1989; Ray, Turkel, \& Marino, 2002). This belief is congruent with the philosophy of symbolic interactionism. The same can be said for education. While both faculty and administrators are focused on the bottom line, education, research, and service to the community served, a clearer understanding of the distinct perspectives and roles of each is integral to the success of the institution and in the case of this study to the working relationships within the institution and to the success of bargaining negotiations.

The theory of social interactionism guided the focus of this study in understanding the experiences and perspectives of the nine higher education experienced administrators interviewed to gain an in-depth understanding of the administrative perspective of the collective bargaining process and faculty unionization and the factors of unionization and bargaining related to the interpersonal relationships between faculty members and administrators in higher education. Guided by the recognition that human beings are actively involved in interpreting events and actions, symbolic interactionism is based on the belief that it is this interpretation process that will be the basis for the individual's decision making and resulting actions related to that event (Blumer, 1969). This theory of symbolic interactionism also aided in the recognition that even though the event is the same, which in the case of this study was working with unionized faculty members and participating in contract negotiations, all of the involved individuals at the bargaining table may walk away with totally different perspectives related to the unionization and 
bargaining (Birnbaum, 1980). This interpretive process is dynamic in nature, subject to repeated revision with recurrent exposures to the same groups of people and the same events with the advent of contextual change (Stryker, 1980).

The researcher concluded that the bargaining process and working with unionized faculty members was subject to individual interpretation and this individual interpretation will, in turn, influence administrative behaviors and attitudes toward bargaining and professional behaviors and relationships toward and with unionized faculty members. For example, Lori spoke about her perception related to two faculty members on the negotiating team. She had heard that they would take whatever was said during negotiations and use it in a negative way outside of the negotiating room. She shared that when the lead administrative negotiator told her this, she interpreted his message as meaning that she should not talk at all while at the negotiation table for fear that whatever she said could be used against her and the administrative bargaining team. Lori shared that she never said a word, even if she recognized that her administrative team had misunderstood an issue that was being negotiated. Thus, the researcher recommends that future studies related to bargaining and unionization in higher education recognize the significance of individual perception and the resulting symbolism that an event or experience holds for that individual and use the theory of symbolic interactionism when attempting to understand more about faculty unionization and bargaining, as well as the beliefs, roles, and behaviors of the key players involved.

\section{Study Summary and Concluding Thoughts}

Based upon the study questions that guided this study, the information shared by the nine higher education administrators interviewed for this study, the related literature 
and the theory of symbolic interactionism, five study findings were reported. The five stated findings related to the higher education administrative perspective of faculty unionization, bargaining, and the factors of both in regards to the interpersonal relationships between faculty and administration included: (a) to be an effectual leader and administrative representative at the bargaining table, one must have an understanding of what it is that faculty does and how they go about doing it, (b) the administrators experienced role ambiguity and role strain because they were not adequately prepared for collective bargaining, (c) the administrators perceived that their institutions offered them little or no training related to collective bargaining negotiations, (d) the administrators felt that faculty unionization and collective bargaining resulted in a divisive split between faculty and administrators, and (e) faculty bargaining was ineffectual in Florida.

Related considerations for practice and future research included: (a) assigning administrators who have served as faculty members to the negotiating team, (b) the scheduling of pre-negotiation meetings between the college president and/or the lead negotiator for the administrative bargaining team and all other administrative representatives assigned to the bargaining team to clearly articulate role expectations and to provide encouragement and support to the administrative team member before, during, and after negations, (c) the offering of in-house training and panel discussions related to bargaining and negotiation issues, (d) the cautious and inclusive revisiting of the concept of centralized state bargaining, and (e) the need for administrators to avoid viewing negotiations from strictly a legal perspective.

The whole process of carrying out this study including the formulation of the study questions, the interviewing of the study participants, and the analysis of the study 
data really opened the researcher's eyes to the realization that although we are often involved in the same activity, which in the case of this study was working with unionized faculty members and participating in collective bargaining negotiations, our perceptions are unique to us and really are based upon our past experiences and relationships. This realization has truly helped the researcher in her everyday practice as a nurse, educator, and higher education administrator. The primary lesson that the researcher learned as a result of this dissertation is that there are many perceptions related to the same event. Each of those individual perceptions has the potential for a variety of actions to be taken. If the perceptions are similar sometimes, the resulting actions may be viewed as positive. If the perceptions of the event are not congruent amongst the participants, the resulting behavior may be viewed in a more negative way. All of this is important when working with unionized faculty members and participating in collective bargaining negotiations. It really cannot nor should not be my way or the highway! There is always much to be learned. Recognizing that everyone at the table is working from their own perspective and framework enforced the need for me to continuously work on communicating information effectively while continuing to question others when I am not clear as to what is being shared, what is expected, and what has not been communicated. 


\section{REFERENCES}

Abraham, S.E., \& Voos, P.B. (2005). The market's reaction to two Supreme Court rulings on American labor law. Journal of Labor Research, 26(4), 677-687.

Allen, N.T., \& Cejda, B.D. (2007). The rural community college as an administrative labor market. Community College Journal of Research and Practice, 31, 261269.

Amey, M.J., VanDerLinden`, K.E., \& Brown, D.F. (2006). Perspectives on community college leadership: Twenty years in the making. In B. Townsend \& D. Bragg (Eds.), ASHE reader on community colleges (pp. 163-172). Boston, MA: Pearson Custom Publishing.

Anderson, J.A. (1997). Leadership training initiatives for community college administrators: A focused synthesis of the literature. Community College Review, 24, 27-54.

Anderson, P., Murray, J.P., \& Olivarez, A. (2002). The managerial roles of public community college chief academic officers. Community College Review, 30(2), $1-26$.

Aronowitz, S. (2000). The knowledge factory: Dismantling the corporate university and creating true higher learning. Boston, MA: Beacon Press.

Aselage, J., \& Eisenberger, R. (2003). Perceived organizational support and psychological contracts: A theoretical integration. Journal of Organizational Behavior, 24, 491-509.

Ashraf, J. (1997). The effect of unions on professors' salaries: The evidence over twenty years. Journal of Labor Research, 18, 439-450.

Babcock, L., \& Engberg, J. (1999). Bargaining unit composition and the returns to education and tenure. Industrial and Labor Relations Review, 52(2), 163-178.

Baccaro, L. (2000). Centralized collective bargaining and the problem of "compliance": Lessons from the Italian experience. Industrial and Labor Relations Review, 53(4), 579-601.

Bain, G.S. (1970). The growth of white collar unionism. New York, NY: Oxford University Press.

Balfour, D.L. \& Wechsler, B. (1996). Organizational commitment antecedents and outcomes in public organizations. Public Productivity and Management Review, 19, 256-277. 
Balsmeyer, B., Haubrich, K., \& Quinn, C. (1996). Defining collegiality within the academic setting. Journal of Nursing Education, 35, 264-267.

Barry, C. (1998, September 30) Choosing qualitative data analysis software: Atlas/ti and nudist compared. Sociological Research Online, 3 (3). Retrieved March 23, 2009 from http://wwwsocresonline.org.uk/socresonline/3/3/4.html.

Benedict, M. (1999). The union effect on the earnings distribution in higher education in Ohio. American Economist, 43(1), 57-70.

Benedict, M., \& Wilder, L. (1990). Unionization and tenure and rank outcomes in Ohio universities. Journal of Labor Research, 20(2), 185-201.

Benjamin, E., \& Mauer, M. (Eds.). (2006). Academic collective bargaining. Washington, DC: The American Association of University Professors.

Bensimon, E.M., Neumann, A., \& Birnbaum, R. (2000). Higher education and leadership theory. In J. Bess \& D. Webster (Eds.), Foundations of American higher education (pp. 499-507). Boston, MA: Pearson Custom Publishing.

Benzies, K.M. \& Allen, M.N. (2001). Symbolic Interactionism as a theoretical perspective for multiple method research. Journal of Advanced Nursing, 33(4), 541-547.

Betts, K., Urias, D., Chavez, J. and Betts, K. (2009). Higher education and shifting U.S. demographics: Need for visible administrative career paths, professional development, succession planning, and commitment to diversity. Academic Leadership, 7(2), 1-6.

Birnbaum, R. (1988). How colleges work: The cybernetics of academic organization and leadership. San Francisco: Jossey-Bass Publishers.

Birnbaum, R. (1980). Creative academic bargaining: Managing conflict in the unionized college and university. New York: Teachers College.

Blumer, H. (1969). Symbolic interactionism: Perspective and method. Englewood Cliffs, NJ: Prentice-Hall.

Boeckmann, M.E. \& Dickinson, G.B. (2001). Leadership: Values and performance. Education, 121(3), 494-497.

Bogdan, R.C., \& Biklen, S.K. (2007). Qualitative research for education: An introduction to theories and methods. Boston, MA: Pearson Educational Group, Inc. 
Boris, R.J. (2004). Collective bargaining and community colleges. New Directions for Community Colleges, 125, 41-49.

Bowker, L.H. (1981). The academic dean. Administrator's Update, 3(2), 3-6.

Bray, N.J. (2008). Prescriptive norms for academic deans: Comparing faculty expectations across institutional and disciplinary boundaries. The Journal of Higher Education, 79(6), 692-720.

Brown, R.S. (1969). Collective bargaining in higher education. Michigan Law Review, 67, 1067-1082.

Brown, L., Martinez, M., \& Daniel, D. (2002). Community college leadership preparation: Needs, perceptions, and recommendations. Community College Review, 30(1), 45-73.

Bula, O.A. (2005). A study of public employee labor law in the United States. Unpublished doctoral dissertation. University of Central Florida, Orlando, Florida.

Carpenter, D.M. (2005). Presidential rhetoric and the purpose of American education. The Educational Forum, 69(3), 278-290.

Castro, C.R. (2000). Community college faculty satisfaction and the faculty union. New Directions for Institutional Research, 105, 45-54.

Cejda, B., McKenney, C.B. \& Burley, H. (2001). The career lines of chief academic officers in public community colleges. Community College Review, 28(4), 31-46.

Christensen, C. (2004). Travel tips for a journey into academic administration. Journal of Nursing Education, 43(11), 512-516.

Cohen, M.D. \& March, J.D. (1974). Leadership and ambiguity. Boston, MA: Harvard Business School Press

Cohen, E., Walsh, K., \& Biddle, R. (2008). Invisible ink in collective bargaining: Why key issues are not addressed. Proceedings of the New School Venture Fund, Washington, May 20, 2008.

Connell, M.A. \& Savage, F.G. (2001). Does collegiality count? Academe, 87 (6), 37.

Cooke, W, Mirsha, A., Spreitzer, G., \& Tschirhart, M. (1995). The determinants of NLRB decision- making revisited. Industrial and Labor Relations Review, 48, 237-257. 
Creswell, J.W. (1998). Qualitative inquiry and research design. Thousand Oaks, CA: Sage Publications.

DelFavero, M. (2003). Faculty-administrator relationships as integral to high-performing governance systems: New frameworks for study. American Behavioral Scientist, 46(7), 902-922.

Deutsch, M. (1973). The resolution of conflict: Constructive and destructive processes. Binghamton, NY: Vail-Ballou Press.

Duryea, E.D., Fisk, R.S. \& Associates (1973). Faculty unions and collective bargaining. San Francisco, CA: Jossey-Bass.

Eaton, A.E. \& Kriesky, J. (1998). Decentralization of bargaining structure: Four cases from the U.S. paper industry. Relations Industrielles, 53(3), 486-516.

Eddy, P.L. (2010). Leaders as linchpins for framing meaning. Community College Review, 37(4), 313-332.

Eisenberger, R., Armeli, S., Rexwinkel, B., Lynch, P., \& Rhoads, L. (2001). Reciprocation of perceived organizational support. Journal of Applied Psychology, 86(1), 42-51.

Eisenberger, R., Huntington, R., Hutchison, S., \& Sowa, D. (1986). Perceived organizational support. Journal of Applied Psychology, 71(3), 500-507.

Eisenberger, R., Stinglhamber, F., Vandenberghe, C., Sucharski, I., \& Rhoads, L. (2002). Perceived supervisor support: Contributions to perceived organizational support and employee retention. Journal of Applied Psychology, 87(3), 565-573.

Falvey, A. (2002). Adversaries and collaborators in collective bargaining negotiations between teacher unions and school districts: Perceptions of key stake holders in Florida public schools. Unpublished doctoral dissertation, University of Central Florida, Orlando.

Fiorito, J.T. \& Gallagher, V.C. (2006). Renewal in the United Faculty of Florida: Class war in paradise? Labor Studies Journal, 31(3), 39-64.

Fogg, P. (2006). Young Ph.D.'s say collegiality matters more than a salary. The Chronicle of Higher Education, 53(6), A11-A12.

Fraenkel, J.R., \& Wallen, N.E. (2003). How to design and evaluate research in education. New York, NY: McGraw-Hill. 
Fuller, J.B., Hester, K., Barnett, T., Frey, L., \& Relyea, C. (2006). Perceived organizational support and perceived external prestige: Predicting organizational attainment for university faculty, staff, and administrators. The Journal of Social Psychology, 146(3), 327-347.

Garbarino, J.W. \& Aussieker, B. (1975). Faculty bargaining: Change and conflict. New York, NY: McGraw-Hill Book Company.

Gerdes, E.P. (2003). Do it your way: Advice from senior academic women. Innovative Higher Education, 27(4), 253-275.

Goldberg, M.J. (2000). An overview and assessment of the law regulating internal union affairs. Journal of Labor Research, 21(1), 15-36.

Goode, W.J., (1960). A theory of role strain. American Sociological Review, 25 (4), 483496.

Gunderson, M. (2005). Two faces of union voice in the public sector. Journal of Labor Research, 26(3), 393-413.

Hannay, M. (2002). The unionization of professionals: A case study. Journal of Labor Research, 23(3), 487-498.

Hemmasi, M., \& Graf, L.A. (1993). Determinants of faculty voting behavior in union representation elections: A multivariate model. Journal of Management, 19(1), 13-32.

Hull, J.R., \& Keim, M.C. (2007). Nature and status of community college leadership development programs. Community College Journal of Research and Practice, 31, 689-702.

Hutchison, S. (1997). Perceived organizational support: Further evidence of construct validity. Educational and Psychological Measurement, 57, 1025-1034.

Jette, M.R. (2005). Exploring table talk: Does dialogue or debate correspond to success and satisfaction in teacher collective bargaining? Unpublished doctoral dissertation, University of New Hampshire, Durham.

Johnson, L. \& Borman, K.M. (2007). Competing agendas for university governance: Placing the conflict between Jeb Bush and Bob Graham in context. In K.M. Borman \& S. Dorm (Eds.), Education reform in Florida: Diversity and equity in public policy (pp. 185-210). Albany, NY: State University of New York Press.

K-20 Education Code, 1001.64. (2010). Community college boards of trustees; powers and duties. 
K-20 Education Code, 1001.705. (2010). Responsibility for the state university system.

Kaplin, W.A., \& Lee, B.A. (1995). The law of higher education: A comprehensive guide to legal implications of administrative decision making. New York, NY: JosseyBass.

Kaufman, B.E. (2005). Historical insights: The early institutionalists on trade unionism and labor policy. Journal of Labor Research, 26(1), 1-32.

Kezar, A. (2004). What is important to effective governance: Relationships, trust, and leadership, or formal structures with formal processes? New Directions for Higher Education, 127, 35-46.

LeBlanc, P. (1999). A short history of the U.S. working class: From colonial times to the twenty-first century. Amherst, NY: Humanity Books.

LeCompte, M. D. (2000). Analyzing qualitative data. Theory into Practice, 39(3), 146154.

Lewin, D. (2005). Unionism and employment conflict resolution: Rethinking collective voice and its consequences. Journal of Labor Research, 26(2), 209-239.

Lieberson, S. and O'Connor, J.F. (1972). Leadership and organizational performance: A study of large corporations. American Sociological Review, 37(2), 117-130.

Levin, J.S. (2000). The revised institution: The community college mission at the end of the twentieth century. Community College Review, 28(2), 1-25.

Lovell, C.D. \& Trouth, C. (2002). State governance patterns for community colleges. In T.H. Bers, \& H.D. Calhoun (Eds.), Next steps for the community college (pp. 91100). New Directions for Community Colleges, No. 117. San Francisco, CA: Jossey-Bass.

MacTaggert, T.J. (2004). The ambiguous future of public higher education systems. In W.G. Tierney (Ed.), Competing conceptions of academic governance (pp. 104136). Baltimore, MD: The Johns Hopkins University Press.

Mauer, M. (2001). The union member's complete guide: Everything you want and need to know about working union. Annapolis, MD: Union Communication Services, Inc.

McCartin, J.A. (2008). “A Wagner Act for public employees": Labor's deferred dream and the rise of conservatism, 1970-1976. The Journal of American History, 95(1), 123-148. 
McFarlin C.H., Crittenden, B.J., \& Ebbers, L.H. (1999). Background factors common among outstanding community college presidents. Community College Review, 27(3), 19-32.

Mead, G., (1934). Mind, self and society. Chicago, IL: The University of Chicago Press.

Mech, T. (1997). The managerial roles of chief academic officers. The Journal of Higher Education, 68, 282-298.

Meindl, J.R. (1987). The romance of leadership and the evaluation of organizational performance. Academy of Management Journal, 30(1), 91-109.

Merriam, S.B., (1998). Qualitative research and case study applications in education. San Francisco, CA: Jossey-Bass.

Metchick, R.M., \& Singh, P. (2004). Yeshiva and faculty unionization in higher education. Labor Studies Journal, 28(4), 45-65.

Miles, M.B., \& Huberman, A.M. (1994). Qualitative data analysis. Thousand Oaks, CA: Sage Publications.

Morin, K.H. \& Reilly, L. (2004). Faculty roles in supporting new deans and directors. Journal of Nursing Education, 43(11), 520-523.

Murray, J.P., \& Murray, J.I. (1998). Job satisfaction and the propensity to leave an institution among two-year college division chairpersons. Community College Review, 25(4), 45-59.

Murray, J.P., Murray, J.I., \& Summar, C. (2000). The propensity of community college chief academic officers to leave an institution. Community College Review, 28(3), 22-36.

Myers, C.J. (2003). A study of the influence of unionization on faculty job satisfaction, organizational commitment, and intent to leave. Unpublished doctoral dissertation, Pennsylvania State University, Pennsylvania.

Naples, C.J. (1993). How to organize the administration of a multi-campus system for bargaining. In D.J. Julius (Ed.), Managing the industrial labor relations process in higher education. Washington: The College and University Personnel Association.

National Labor Relations Board v. Health Care \& Retirement Corporation of America, 511 U.S.571 (1994). 
National Labor Relations Board v. Yeshiva University, 444 U.S. 672 (1980).

O'Connell, J.F. (2001). The NLRB at the grassroots. Journal of Labor Research, 22(4), 761-775.

Odewahn, C.A., \& Spritzer, A.D. (1976). Administrators' attitudes toward faculty unionism. Industrial Relations, 15(2), 206-215.

Pascarella, E.T., \& Terenzini, P.T. (2005). How colleges affect students: A third decade of research. San Francisco, CA: Jossey-Bass.

Patton, M.Q. (2002). Qualitative research and evaluation measures. Thousand Oaks, CA: Sage.

Piskulich, J.P. (1992). Collective bargaining in state and local government. New York, NY: Praeger Publishers.

Plinske, K. \& Packard, W. (2010). Trustees' perceptions of the desired qualifications for the next generation of community college presidents. Community College Review, 37(4), 291-312.

Public Employees Relations Commission. (2004). A practical handbook on Florida's public employment collective bargaining law. Tallahassee, Florida: State of Florida Printing Office.

Public Employees Relations Commission. (2002). Career services appeals under service first. Tallahassee, Florida: State of Florida Printing Office.

Putten, J., McLendon, M. \& Peterson, M. (1996, May) Comparing union and nonunion Staff perceptions of the higher education work environment. Paper presented at the Thirty-Sixth Annual Forum of the Association for Institutional Research, Albuquerque, New Mexico.

Ramamurti, R. (2001). The obsolescing 'bargaining model'?; MNC-host developing country relations revisited. Journal of International Business Studies, 32(1), 2339.

Rassuli, A., \& Karim, A. (1999). The effect of experience on faculty attitudes toward collective bargaining: A cross-temporal analysis. Journal of Labor Research, 20(2), 203-218.

Ray, M. (1989). The theory of bureaucratic caring for nursing practice in the organizational culture. Nursing Administration Quarterly, 13(2), 31-42. 
Ray, M.A., Didominic, V.A., Dittman, P.W., Hurst, P.A., Seaver, J.B., et al. (1995). The edge of chaos: Caring and the bottom line. Nursing Management, 26(9), 48-50.

Ray, M.A., Turkel, M.C., \& Marino, F. (2002). The transformative process for nursing in workforce redevelopment. Nursing Administration Quarterly, 26(2), 1-14.

Reille, A. \& Kezar, A. (2010). Balancing the pros and cons of community college "grow your own” leadership programs. Community College Review, 38(1), 59-81.

Rhoads, L. \& Eisenberger, R. (2002). Perceived organizational support: A review of the literature. Journal of Applied Psychology, 87(4), 698-714.

Risacher, J. (2004). The extent to which four-year college presidents who previously served as senior student affairs officers report having the characteristics of effective presidents. NASPA Journal, 41(3), 436-451.

Rocco, T.S. (2003). Shaping the future: Writing up the method on qualitative studies. Human Resource Development Quarterly, 14(3), 343-349.

Romero, M., Purdy, L., Rodriquez, L., \& Richards, S. (2005). Research needs and practices of community-college practitioners. Community College Journal of Research and Practice, 29, 289-302.

Saltzman, G.M. (1998). Legal regulation of collective bargaining in colleges and universities. The NEA 1998 Almanac of Higher Education.

Schuster, P.M. (2008). Concept mapping: A critical-thinking approach to care planning. Philadelphia, PA: F.A. Davis Company.

Seidman, I. (2006). Interviewing as qualitative research: A guide for researchers in education and the social sciences. New York, NY: Teachers College Press.

Shanock, L. R., \& Eisenberger, R. (2006). When supervisors feel supported:

Relationships with subordinates' perceived supervisor support, perceived organizational support, and performance. Journal of Applied Psychology, 91(3), 689-695.

Shumar, W. (1997). College for sale: A critique of the commoditization of higher education. Bristol, PA: The Falmer Press.

Slaughter, S., \& Rhoades, G. (2004). Academic capitalism and the new economy: Markets, states and higher education. Baltimore, MD: The Johns Hopkins University Press. 
Stake, R. (2005). Qualitative case studies. In N. Denzin \& Y. Lincoln (Eds.) The Sage handbook of qualitative research (pp. 443-466). Thousand Oaks, CA: Sage Publications.

Stryker, S. (1980). Symbolic interactionism. Menlo Park, CA: The Benjamin/Cummings Publishing Company.

Tedrow, B., \& Rhoads, R.A. (1999). A qualitative study of women's experiences in community college leadership positions. Community College Review, 27(3), 118 .

Thaxter, L.P., \& Graham, S.W. (1999). Community college faculty involvement in decision-making. Community College Journal of Research and Practice, 23, $655-674$.

The 2010 Florida Statutes, Chapter 447. Retrieved November 19, 2010 from http://www.leg.state.fl.us/statutes.

Thelin, J.R. (2004). A history of American higher education. Baltimore, MD; The Johns Hopkins University Press.

Thomas, A.B. (1988). Does leadership make a difference to organizational performance? Administrative Science Quarterly, 33(3), 388-400.

Tierney, W.G. (2000). Symbolism and presidential perceptions of leadership. In M.C. Brown (Ed.), Organization and governance in higher education (pp. 223-232). Boston, MA: Pearson Custom Publishing.

Trombly, W. (2001). Florida’s new “K-20” model. National Crosstalk, 9(2), 1-12.

United Faculty of Florida and Florida Public Employees Council 79, American Federation of State, County, and Municipal Employees, AFL-CIO, Apellants, $v$ Public Employees Relations Commission, Florida State University Board of Trustees and University of West Florida Board of Trustees, Appellees, ID03-4689 (2005).

Vinel, J. (2007). The old has been dying and the new is yet to be born: A short note on the history of the employee. Labor History, 48(2), 195-208.

Walton, R.E. \& McKersie (1965). A behavioral theory of labor negotiations: An analysis of a social interaction system. Ithica, NY: ILR Press.

Weiss, R.S. (1994). Learning from strangers: The art and method of qualitative interview studies. New York, NY: The Free Press. 
Wepner, S.B., Wilhite, S. C., \& D'Onofrio, A. (2003). Understanding four dimensions of leadership as education deans. Action in Teacher Education, 25(3), 13-23.

Wild, L.L., Ebbers, L.H. \& Shelley, M.C. (2003). Stress factors and community college deans: The stresses of their role identified. Community College Review, 31(3), 123.

Wolfe, M. P. (2001). Reflections on the most important educational developments of the $20^{\text {th }}$ century: Kappa delta pi laureates. The Educational Forum, 65(2), 146-163.

Wolverton, M., Wolverton, M.L., \& Gmelch, W.H. (1999). The impact of role conflict and ambiguity on academic deans. The Journal of Higher Education, 70(1), 80106.

Yates, M. (1998). Why unions matter. New York, NY: Monthly Review Press.

Zagelmeyer, S. (2005). The employer's perspective on collective bargaining centralization: An analytical framework. The International Journal of Human Resource Management, 16(9), 1623-1639 
APPENDIX A

STUDY INTERVIEW GUIDE 


\section{STUDY INTERVIEW GUIDE}

I. Past - how did the participant come to be an administrator working with unionized faculty members and participating in union negotiations:

- For the next 20-30 minutes going back as far as you can, please tell me about some of your earlier life experiences and relationships that you feel may have impacted your current role as an administrator and collective bargaining participant (family, educational background, working experiences, etc.).

- What in particular led to your interest in working as an administrator in higher education?

- How did you end up at the bargaining table?

- Please talk about any formal or informal training that you underwent before actually participating in the collective bargaining process.

II. Present - what is it like to be an administrator involved with collective bargaining and unionized faculty members:

- Taking a moment, think about your typical day at work and then describe that day to me including places that you may go, people that you come into contact with and events that take place.

- Which places, people and events do you enjoy the most? Why? How do they make you feel?

- Walk me through your most typical collective bargaining session.

- Describe what you were thinking/feeling while sitting at the bargaining table?

- Tell me about an incident that occurred during bargaining that you found disturbing.

- Tell me about a specific conversation that took place with a faculty member during a collective bargaining session related to the negotiations.

- Tell me about a conversation that you had with another administrator who was also participating in negotiations during a bargaining session.

- Overall, did you feel prepared for what took place during the bargaining session?

- Was there a time during in negotiations when you felt proud?

- Was there a time during in negotiations when you felt embarrassed?

III. Reflections \& Future-look for meaning

- Pretend that I am new to higher education administration. I will be working with unionized faculty members. What should I know?

- I have been asked to represent administration at the bargaining table. What should I know?

- It is thought by some that faculty members are hesitant to join the union and to participate in collective bargaining sessions due to the perceived threat of administrative retaliation perhaps in the form of not offering tenure, or with holding promotions. What would you say to these faculty members? 
- Collegiality assumes that traditional faculty conflicts with administrators can be resolved through traditional academic interactions. What do you think about collegiality versus collective bargaining?

- What was it like for you on campus after negotiations?

- Would you say that it is more difficult to work with faculty members who are unionized or not unionized and why?

- Now that you have gone through the process of negotiations, what would you do differently before participating again?

- Describe what the process of negotiation was like for you while focusing on what the other participants were saying and doing?

- How did you feel about yourself after the negotiations ended?

- Think about one person's behavior that had the greatest impact on you during the negotiation process. What would you say to that person now?

- In your opinion, is there a place in higher education for unionization? Why or why not?

- Before we conclude our interview, I would like to ask you a few questions about yourself related to your demographic makeup. Before I begin though, is there anything else that you would like to tell me related to faculty unionization and the collective bargaining process in higher education?

IV. Probes:

- What led to that?

- What else was happening?

- What was it like for you when....?

- Can you describe a specific incident that highlights that?

- I am not sure that I understand, talk more about .......

- What do you mean by...?

- Elicit more detail.

- Okay, now there is another issue that I want to ask you about.... 
APPENDIX B

CONSENT FORM 


\section{STUDY CONSENT FORM}

\section{CONSENT TO PARTICIPATE IN A RESEARCH STUDY}

\section{Title: Collective Bargaining and Faculty Unionization: The Administrative}

\section{Perspective}

You are being asked to participate in a research study that is being conducted by Colleen M Quinn, study investigator, a graduate student at Florida International University (FIU). The study will include approximately 6-10 higher education administrators who have worked with unionized faculty members and who have participated in collective bargaining sessions. The two study interviews will require 90 minutes of your time per interview. We will be discussing your overall perspective related to the effects of faculty unionization and collective bargaining based upon your past experiences with such; as well as the impact that your participation in the collective bargaining sessions has had on your interpersonal relationships with faculty members and other administrators.

If you decide to be a part of the study we will set up a mutually agreed upon time and place for an initial and a follow up semi-structured interview to take place. Your participation in this study will be strictly voluntary and will not expose you to any more risk than would be taken in your regular daily activities. You may ask questions at any time during the study. You may withdraw your consent to participate at any time should you become uncomfortable with any part of the interview. Should you choose not to participate in this study there will be no ill feelings or penalties of any type. There is no cost or payment to you as a participant. You will not acquire any direct benefit from participating in this study. Your participation will however help us to give information to other's who are interested in faculty unionization and the collective bargaining process in the higher education setting.

Your interview will be identified by a pseudonym not your name or any other identifying information such as birth date, social security number, etc. The interview transcript will

not be shared with anyone unless required by law. Your data will be compared to the data of the other study participants. The research results will be presented as compiled data from all of the study participants.

If you would like more information about this research once the interviews have been completed, you can contact Dr. Benjamin Baez or me at 305-348-3214. If you feel that you were mistreated or would like to talk with someone about your rights as a volunteer in this research study you may contact Dr. Patricia Price, Chairperson of the FIU Institutional Review Board at 305-348-2618 or 305-348-2494. 
APPENDIX C

DEMOGRAPHIC INFORMATION 


\section{DEMOGRAPHIC INFORMATION FORM \\ DEMOGRAPHIC INFORMATION FORM}

Participant Pseudonym:

Date:

Professional Title:

Length of time in Current Position:

Type of Institution Employed At:

Number of Years Employed in Higher Education:

Number of Years Employed as a Faculty Member:

Professional Discipline as a Faculty Member:

Number of Years Employed as an Administrator:

Any Past Union Affiliations as a Member of Such:

Current Age Group:

20-29

30-39

$40-49$

$50-59$

60-69

$70-79$

Highest Educational Degree Received: 
VITA

\section{COLLEEN M. QUINN}

\begin{tabular}{|c|c|}
\hline 1977 & $\begin{array}{l}\text { A.A.S., Nursing } \\
\text { Trocaire College } \\
\text { Buffalo, New York }\end{array}$ \\
\hline 1991 & $\begin{array}{l}\text { B.A., Psychology } \\
\text { Southern Illinois University } \\
\text { Carbondale, Illinois }\end{array}$ \\
\hline 2000 & $\begin{array}{l}\text { M.S., Nursing } \\
\text { Florida Atlantic University } \\
\text { Boca Raton, Florida }\end{array}$ \\
\hline $1975-2000$ & $\begin{array}{l}\text { Registered Nurse } \\
\text { Various locations throughout the U.S. }\end{array}$ \\
\hline $2000-2005$ & $\begin{array}{l}\text { Assistant Professor of Nursing } \\
\text { Broward Community College } \\
\text { Pembroke Pines, Florida }\end{array}$ \\
\hline $2005-2010$ & $\begin{array}{l}\text { Associate Dean for Nursing } \\
\text { Broward Community College } \\
\text { Pembroke Pines, Florida }\end{array}$ \\
\hline 2010-2011 & $\begin{array}{l}\text { Assistant Professor of Nursing } \\
\text { Broward College } \\
\text { Pembroke Pines, Florida }\end{array}$ \\
\hline 2011-present & $\begin{array}{l}\text { Associate Dean for Nursing } \\
\text { Broward College } \\
\text { Pembroke Pines, Florida }\end{array}$ \\
\hline
\end{tabular}

